\title{
WestVirginiaUniversity
}

THE RESEARCH REPOSITORY @ WVU

Graduate Theses, Dissertations, and Problem Reports

2002

\section{Zinc pot bearing material wear rate as a function of contact pressure and velocity}

James M. Snider II

West Virginia University

Follow this and additional works at: https://researchrepository.wvu.edu/etd

\section{Recommended Citation}

Snider, James M. II, "Zinc pot bearing material wear rate as a function of contact pressure and velocity" (2002). Graduate Theses, Dissertations, and Problem Reports. 1518.

https://researchrepository.wvu.edu/etd/1518

This Thesis is protected by copyright and/or related rights. It has been brought to you by the The Research Repository @ WVU with permission from the rights-holder(s). You are free to use this Thesis in any way that is permitted by the copyright and related rights legislation that applies to your use. For other uses you must obtain permission from the rights-holder(s) directly, unless additional rights are indicated by a Creative Commons license in the record and/ or on the work itself. This Thesis has been accepted for inclusion in WVU Graduate Theses, Dissertations, and Problem Reports collection by an authorized administrator of The Research Repository @ WVU. For more information, please contact researchrepository@mail.wvu.edu. 


\title{
Zinc Pot Bearing Material Wear Rate as a Function of Contact Pressure and Velocity
}

\author{
By \\ James M. Snider II \\ THESIS \\ Submitted To \\ The College of Engineering and Mineral Resources \\ West Virginia University
}

In partial fulfillment of the requirements

For the degree of

Master of Science in Mechanical Engineering

John Loth, Ph.D., Chair

Gary Morris, Ph.D.

Xingbo Liu, Ph.D.

Department of Mechanical and Aerospace Engineering

\author{
Morgantown, West Virginia \\ 2002
}

Keywords: Bearing Material Wear, Friction Coefficient, Zinc-Pot 


\section{Abstract \\ By \\ James M. Snider II}

There are currently over 50 galvanizing lines in operation in the United States producing approximately 50 million tons per year of galvanized sheet. Frequently zincpot hardware fails which causes production delay, resulting in an economic loss. It takes approximately 3 hours to change the zinc-pot bearings at a downtime cost of $\$ 1600 / \mathrm{h}$.

To predict the performance of the submerged bearings, a large number of variables must be considered. These variables include pot chemistry, temperature, line speed and line tension. With these variables it is possible to develop a design guide for sheet mill operators to determine the most cost-effective selection of zinc pot bearing materials/coatings, which will not be the same for all galvanizing lines.

The objective of this project is to measure wear rate of submerged zinc pot bearing materials as a function of contact pressure and velocity. A small laboratory sizetesting machine was developed for this purpose. This machine measures the wear of bearing material samples, submerged in a cup of zinc, in the form a 1-inch diameter ball rotating against a matched ball seat. The seat and ball can be cast or machined using bearing materials from a test matrix. The seat is placed in a temperature controlled molten zinc bath where load, torque and RPM of the test samples are measured and recorded. From the measured torque the sliding friction coefficient of the bearing materials tested can be calculated. By measurement of the seat radius before and after testing, the wear rate of the material as a function of contact pressure and velocity was determined. 


\section{Acknowledgements}

I would like to thank Dr. John Loth for serving as my research advisor and giving me the opportunity to work with him as a graduate student. I would like to thank Dr. Gary Morris for his guidance throughout my Masters Degree program and also for serving on my committee. I would like to thank Chuck Coleman and Dr. Mike Palmer for helping with this project. I would like to thank my friend and colleague Ryan Ware for guiding me through my start in this project. A special thanks to Tim Burlingame for his help in completing my research for this project.

A very special thanks to my family. To my mother and father, Jim and Linda Snider, for their encouragement and guidance throughout my college career. To my grandmother, Wilma Bizaro, for her help and knowledge during this program. A very special thanks to Erin Lee who provided the best moral and mental support that one could ever hope for.

I appreciate being supported by the DOE Contract DE-PS07-001D13964 throughout this effort.

I greatly appreciate the sample specimens provided at no cost for my research. I would like to thank Mike Brennan of Praxair Surface Technologies for providing the Stellite \#6 weld overlay and the laser-clad tungsten carbide ball and seat specimens. I would also like to thank Mark Bright for the MSA 2012 and 2020 samples. And a special thanks to Ed Dean of Vesuvius McDanel who provided ceramic seat specimens and Vinod Sikka who provided both cast Stellite \#6 and ORNL-4 ball and seat samples. 


\section{Contents}

Title Page $\quad$ i

$\begin{array}{lll}\text { Abstract } & \text { ii }\end{array}$

$\begin{array}{ll}\text { Acknowledgements } & \text { iii }\end{array}$

Contents iv

List of Tables vi vi

List of Figures vii

Nomenclature $\quad x$

Chapter 1 - Introduction 1

Chapter 2 - Review of Relevant Literature 3

2.1 New Material Research and Life Improvement for Pot Hardware 3

2.2 BOCLE and HFRR Wear Testing 5

2.3 Teck Cominco's Continuous Galvanizing Line Submerged 7 Hardware Research

2.4 WVU's Lubricity Research and Testing Apparatus 12

$\begin{array}{ll}\text { 2.5 Zinc Pot Bearing Material Research } & 15\end{array}$

2.6 Arcelor Research's Bearing Tester for Bath Hardware Material $\quad 18$

2.7 WVU's Zinc Pot Bearing Material Tester 23

Chapter 3 - Material Wear Tester for Zinc Pot Bearings 35

3.1 Improvement of Torque Strain Gage beam 35

3.2 Design of New Test Spindle 37

3.3 Zinc Pot Failure $\quad 39$

Chapter 4 - On-Line Data Acquisition Computer Program 40

Chapter 5 - Friction Coefficient and Wear Data Analysis Procedure 41 
5.1 Friction Coefficient and Wear Data Analysis Procedure

5.2 Wear Analysis Procedure

Chapter 6 - Wear and Friction Coefficient Results

6.1 Material Test Conditions

6.2 Test Sample Sources 


\section{List of Tables}

Table 2.1: Results from Teck Cominco's Wear and Friction Testing 9

Table 2.2: Teck Cominco's Static Immersion Tests 10

Table 2.3: Results of EDS Analysis on the Alloy Layers of the 316L Bushing 11

Table 2.4: Results of EDS Analysis on the Alloy Layers of the Stellite \#6 Sleeve 11

Table 2.5: Machinists Handbook Friction Coefficients 14

Table 2.6: Results of WVU's Friction Coefficient Test Apparatus 14

Table 2.7: Weirton Steel Operational Galvanizing Lines Data Ranges 25

Table 2.8: Correlation Between Steel Mill and Tester Operating Conditions 26

Table 2.9: Weirton Steel Operational Ranges Converted to WVU's Zinc 28

Pot Bearing Materials Tester

Table 2.10: Initial Material Test Matrix 32

Table 5.1: Calibration Constants for Materials Tester 41

Table 6.1: Wear Rate and Friction Power of Various Material Combinations 61

Table C.1: Chemical Composition Analysis for Molten Zinc Used in Testing 77 


\section{List of Figures}

Figure 2.1: Diagram of Pot Hardware in Continuous Hot-Dip Process 5

Figure 2.2: Diagram of Teck Cominco's Test Apparatus $\quad 8$

Figure 2.3: Teck Cominco's Friction Coefficient Data of Pin and Disc Materials 9

Figure 2.4: WVU Lubricity Test Apparatus 13

Figure 2.5: Effect of Fuel Additives on Friction Coefficient 14

Figure 2.6: Flow Chart of Powder Production by Hot Isolated Pressing 17

Figure 2.7: Picture of Arcelor's Test Apparatus 19

Figure 2.8: Picture of Arcelor's Test Specimen $\quad 20$

Figure 2.9: Friction Coefficient as a Function of Time for 21

Stellite \#6 on Stellite \#6 in Arcelor's Tester [12]

Figure 2.10: Wear as a Function of Time for

Stellite \#6 on Stellite \#6 in Arcelor's Tester [12]

Figure 2.11: Wear as a Function of Time at Different

Applied bearing Loads for Stellite \#6 on Stellite \#6 [12]

Figure 2.12: Evolution of Friction Coefficient with Time for

Stellite \#6 on Stellite \#6 [12]

Figure 2.13: Schematic of Galvanizing Line Roller and Bearing 24

Figure 2.14: Ball and Seat Specimen Diagram $\quad 27$

Figure 2.15: Cross Section of the Bearing Track Assembly 29

Figure 2.16: Picture of Bearing Track Assembly and Cup Torque Transfer Plate 30

Figure 2.17: Water Cooled Spindle 31

Figure 2.18: Stainless Steel Strut Channel and Seat 33

Figure 2.19: Stainless Steel Strut Channel and Seat Bolted into Specimen Cup 33

Figure 2.20: Assembled Zinc Pot Bearing Materials Tester 34 
Figure 3.1: Improved Torque Strain Gage Beam

Figure 3.2: Rotating Spindle Design 38

Figure 5.1: Measurement Locations on Seat Specimen 43

Figure 5.2: Wear Location of Seat Specimen 44

Figure 6.1: Contact Velocity as a Function of Bearing Tester RPM with 46

Symbols Indicating Typical Contact Velocities Employed at Weirton Steel

Figure 6.2: Contact Pressure as a Function of Spindle Load with

Symbols Indicating Typical Contact Pressures Used at Weirton Steel

Figure 6.3: Wear of Stainless Steel on Stainless Steel as a Function of 48

Time at an Initial Contact Pressure of 100 psi and Various Contact

Velocities in Water

Figure 6.4: Wear as a Function of Contact Pressure for Stainless Steel on

Stainless Steel at Various Contact Velocities in Water

Figure 6.5: Wear Rate of Stainless Steel on Stainless Steel in Water and Curve 50 Fitted as a Function of Contact Pressure and Velocity

Figure 6.6: Wear of Stellite \#6 on Stellite \#6 as a Function of Time in Water 51 at a Contact Pressure of $100 \mathrm{psi}$ and a Contact Velocity of 4.56 inches/sec

Figure 6.7: Wear as a Function of Contact Pressure for a Stellite \#6 Ball on a 52 Stellite \#6 Seat at a Contact Velocity of 4.66 inches/sec in Water

Figure 6.8: Wear Rate of Stellite \#6 on Stellite \#6 in Water and Curve Fitted as a 53 Function of Contact Pressure and Velocity

Figure 6.9: Friction Coefficient of a MSA 2012 Ball on a 54 Stellite \#6 Seat as a Function of Time

Figure 6.10: Friction Coefficient of a MSA 2012 Ball on a 55

Laser-Clad Tungsten Carbide Seat as a Function of Time

Figure 6.11: Friction Coefficient of a MSA 2020 Ball on a 56

Laser-Clad Tungsten Carbide Seat as a Function of Time

Figure 6.12: Friction Coefficient of a MSA 2020 Ball on a 57

MSA 2012 Seat as a Function of Time

Figure 6.13: Friction Coefficient of a MSA 2012 Ball on a 58 
MSA 2012 Seat as a Function of Time

Figure 6.14: Friction Coefficient of a Stellite \#6 Ball on a

MSA 2012 Seat as a Function of Time

Figure 6.15: Friction Coefficient of a Laser-Clad Tungsten

Carbide Ball on a MSA 2012 Seat as a Function of Time

Figure 6.16: Average Friction Coefficients of

Bearing Material Combinations

Figure 6.17: Friction Power of Bearing Material Combinations 65

Figure 6.18: Material Combinations Wear Rate as a

66

Function of Bearing Power Loading

Figure B.1: Calibration Curve for Torque Strain Gage Beam $\mathrm{F}_{\text {gage }}$ with

Moment Arm $1_{\text {Gage }}=6.75$-inch

Figure B.2: Calibration Curve for Load Cells

Figure B.3: Calibration Curve for RPM Sensor 


\section{Nomenclature}

$\mathrm{A}_{\mathrm{B}}$

$\mathrm{A}_{\text {hor }}$

$\mathrm{A}_{\text {hor,f }}$

$\mathrm{A}_{\text {hor, }}$

$\mathrm{A}_{\text {seat }}$

$\mathrm{F}_{\mathrm{B}}$

$F_{\text {gage }}$

$F_{\text {load }}$

$\mathrm{F}_{\text {contact }}$

$\mathrm{P}_{\mathrm{B}}$

$\mathrm{P}_{\mathrm{C}}$

$r_{c}$

$\mathrm{T}_{\mathrm{s}}$

$\mathrm{t}$

TQ

$V_{B}$

$\mathrm{V}_{\mathrm{C}}$

$\mathrm{V}_{\text {Sheet }}$

$\mathrm{W}_{\mathrm{f}}$

$\mathrm{W}_{\mathrm{i}}$

$\Delta \mathrm{W}$

$\mu_{\mathrm{F}}$

$\omega$

$\ell_{\text {gage }}$

Steel mill bearing area

Horizontal projection of laboratory ball on seat contact area

Final horizontal projected seat area

Initial horizontal projected seat area

Laboratory test sample seat contact surface area

Steel mill bearing contact force

Force applied to the strain gage beam

Laboratory vertical spindle load by ball on seat

Resultant of $F_{\text {Load }}$ perpendicular to test sample contact surface

Steel mill bearing pressure

Laboratory ball on seat contact pressure

Mean contact radius of ball on seat

Sheet tension in galvanizing line

Time

Torque

Steel mill bearing contact surface velocity

Laboratory ball on seat contact velocity

Velocity of sheet in galvanizing line

Final seat width

Initial seat width

Change in seat width

Friction coefficient

Uncertainty function

Moment arm from spindle centerline to contact with strain gage beam 


\section{Chapter 1 - Introduction}

This research project is a cooperative effort by West Virginia University, Industries of the Future of WV, International Zinc Research Organization, Oak Ridge National Laboratory, and various Steel Industries for the U.S. Department of Energy. All of these are working together to achieve a significant improvement in galvanizing line zinc-pot bearing life. The proposed five-year project consists of two phases. A multitask approach is adopted for exploration and evaluation of new materials in Phase I for the first three years. The tasks for phase one include, computational design of new materials, corrosion tests of potential materials, coating technology assessment, wear and erosion tests of potential materials, and characterization and mechanistic study of the formation of interface layers and dross. Phase II consists of a scale up and pilot tests of new pot hardware. The life improvement of pot hardware is expected to be an order of magnitude over that of current standard materials used in molten metal baths.

The U.S. total steel production of 100 million tons/year has a value of approximately $\$ 40$ billion. It has been estimated that $50 \%$ of the total steel production is sheet product, much of it sold in galvanized form. Frequent zinc-pot hardware failures increase the cost of energy to produce the product, which significantly reduces the profit margin. It takes approximately three hours to change the zinc-pot bearings at a downtime cost of $\$ 1600 / \mathrm{h}$. Extending bearing life form one week to 3 weeks would save $\$ 163,000$ a

year. On a national scale, where there are 57 operational galvanizing lines, this would correspond to a yearly loss of approximately $\$ 27$ million. Based on this, the need for new material technologies for pot hardware is critical and urgent for the U.S. steel industry. 
Improvement of zinc-pot bearings would have a significant impact on the production cost of continuous hot-dip processes for value-added steel products. 


\section{Chapter 2 - Literature Review}

\subsection{New Material Research and Life Improvement for Pot Hardware}

The coating of steel with protective metals such as zinc or aluminum is an economical means of providing corrosion resistance on various grades of steel. The coating of steel can be performed by a variety of processes, but continuous hot dipping process remains the most economical for mass production. The U.S. Department of Energy published the Steel Industry Road Map in March of 1998. This report indicated three main areas for steel product development consisting of containers, construction products, and automotive products. In each one of these product areas, coating technology was singled out as one of the high priority research and development needs. In order for steel to compete with other structural materials such as aluminum or fiber composites, hot dip operations require further reduction of manufacturing cost as well as energy consumption.

There are four main types of hot-dip coatings [1] developed as a standard in today's steel industry. All four coating materials are alloys of zinc and/or aluminum: 1. galvanize coating $(\mathrm{Zn}) ; 2$. Galfan ${ }^{\circledR}$ coating $(\mathrm{Zn}-5 \% \mathrm{Al}) ; 3$. Galvalume ${ }^{\circledR}$ coating $(45 \% \mathrm{Zn}$ Al); 4. Aluminize coating (Al-8\%Si).

Current galvanizing lines operate continuously, but routine maintenance shutdowns are required periodically. One of the major factors that determine the frequency of shutdowns is the life of the roller bearings submerged in the molten zinc bath. The maintenance of roller bearings requires the cost of downtime in production, as well as the energy loss associated with restarting the continuous operation.

To ensure adequate performance operation, materials for pot hardware must be 
carefully selected. Failure to select the most suitable materials can lead to high maintenance costs, which may arise from extensive repair or replacement, premature and catastrophic failure, and decreased output because of downtime. Satisfactory bath materials must posses the required mechanical strength at operating temperatures, be wear and corrosion resistant to the zinc composition inside the bath, be manufacturable into the desirable component shapes, and have a reasonable cost.

A variety of computer codes with extensive databases have been developed by others to enable researchers to predict the formation different phases on the surface of pot hardware materials. ORNL and WVU have the experience to work with phase computation models in order to identify interface metallic compounds.

The IOF-WV steel group initiated a research team that included technical experts from West Virginia University and Oak Ridge National Laboratory in addition to engineers from West Virginia steel companies. A research team was set up to work on the most critical issues of new materials for pot hardware in continuous hot dip processes.

A typical arrangement for pot hardware is shown in Figure 1. As seen in this Figure, the components submerged in the molten zinc coatings are the rolls, bearings, and snout. The product quality of the hot-dip coating, especially uniformity of the coating layer, is strongly influenced by the condition of hardware submerged in the molten zinc bath. 


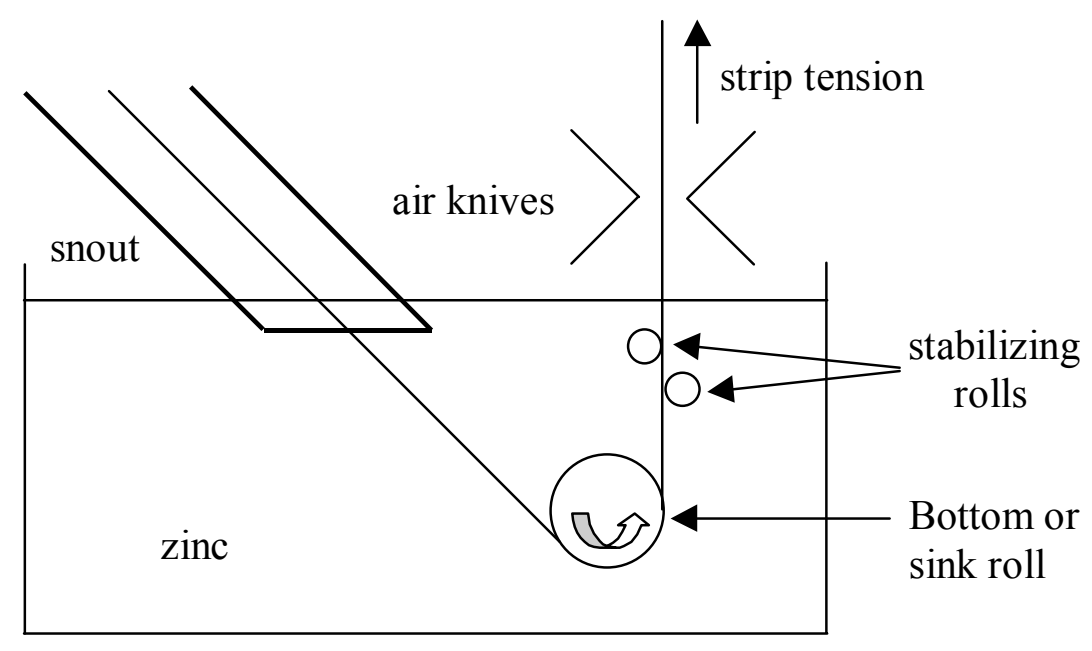

Figure 2.1: Diagram of Pot Hardware in Continuous Hot-Dip Process

There are two types of materials typically used in pot hardware. The rolls, including sink roll and stabilizing roll, are primarily made of $316 \mathrm{~L}$ stainless steel. Roll bearings are generally made of cemented tungsten carbides, WC-Co, commercially known as Stellite \#6. Both of these materials have been used in pot hardware for more than three decades. Their performance was found to be acceptable even before the hotdip process became a fully automated and continuous operation. Based on an International Lead Zinc Research Organization (ILZRO) survey, the average life of pot hardware can vary from approximately seven days to six weeks, with approximately two weeks being the most common. The end of bearing life is dictated by the occurrence of one of the following in the production line: onset of roll skidding, onset of vibration, and no-concentric rotation.

\subsection{BOCLE and HFRR Wear Testing}

Based on available literature it is noted that dynamic wear testing of materials is done with materials being dry or lubricated. "The wear of lubricated bearing surfaces (Bond, et, al [2]) depends not only on the lubricant, but also on the materials used, the 
bearing load, surface finish and velocity at the point of contact. Lack of sufficient lubricating properties increases wear, which alters the surface finish and produces loss of material from the surface. One can experience four types of wear: corrosion, adhesive wear, abrasive wear and surface fatigue. Wear can be reduced by the presence of lubricants and corrosion inhibitors at the point of contact of the wear bodies. Many testing machines have been built to perform these duties, like the four balls wear test, single particle wear test and the BOCLE test. Many have been developed to characterize lubricating fluids. The three most common test methods are: BOCLE (Ball-on-Cylinder Lubricity Evaluator), the HFRR (High Frequency Reciprocating Rig), and field-testing.”

The BOCLE test (American Society for Testing and Materials, 1999 [3]) was designed for testing the lubricity of diesel and jet fuel. This test uses a $1 / 2$ inch diameter ball placed on a cylinder rotating at 244 RPM submerged in the fluid being tested. The test is performed over a 30 minute period with a ball loaded to 9.81 Newtons force. After the test time has elapsed the scar on the ball is measured to the nearest $0.01 \mathrm{~mm}$.

The Lubrizol Scuffing BOCLE test (Lubrizol Corporation, 2000 [4]) is a variation of the standard BOCLE test. This test applies a steady 7 kilogram load to the ball. The test is run for 2 minutes and then the scar on the ball is measured and used to determine the lubricating qualities of the test fluid.

The HFRR test (Rabinowicz, et, al [5]) uses a 1/2-inch ball that is rapidly vibrated back and forth over a flat surface. The ball is moved back and forth over a $1 \mathrm{~mm}$ stroke with a load of 200 grams. The time necessary to wear a scar into the ball is measured and the size of the scar is used to determine the lubricating qualities of the test fluid. 
The BOCLE [2] "has been used for some time, but there are only a few of these machines available at specialty fuel testing labs. HFRR has been accepted by ISO, Society of Automotive Engineers (SAE) and is commonly used in Europe for testing diesel fuel lubricity. The drawback of HFRR is that, there are very few of these testing machines available in North America. Field-testing is good but very expensive."

\subsection{Teck Cominco's Continuous Galvanizing Line Submerged Hardware Research}

The Teck Cominco Product Technology Center in Canada has done extensive testing on characterizing the friction and wear of zinc pot bearing materials. Tests in molten zinc were conducted under simulated line operating conditions. The objective of Teck Cominco's study was to improve the life and performance of bearings submerged in molten zinc in galvanizing lines (Teck Cominco, 1996 [6]). In order to study the friction and wear characteristics of submerged bearing materials a pin on disk testing machine was designed and built, as seen in Figure 2.2. The machine was used to test various materials bearing materials used in zinc pot bearing hardware. It used an electric motor to drive a shaft that supports the testing materials. The materials were in the form of three pins that were installed in a hub that rotated on a fixed plate submerged in a molten zinc pot. The friction torque between the two materials was determined by measurement of the motor current. Contact load to the pins was provided by cylindrical weights on the drive shaft. The tests were performed over a zinc pot temperature range of $450^{\circ} \mathrm{C}$ $470^{\circ} \mathrm{C}$. The bearing material wear was determined by measuring the loss of length of the pins and the depth of the wear groove on the disc. 


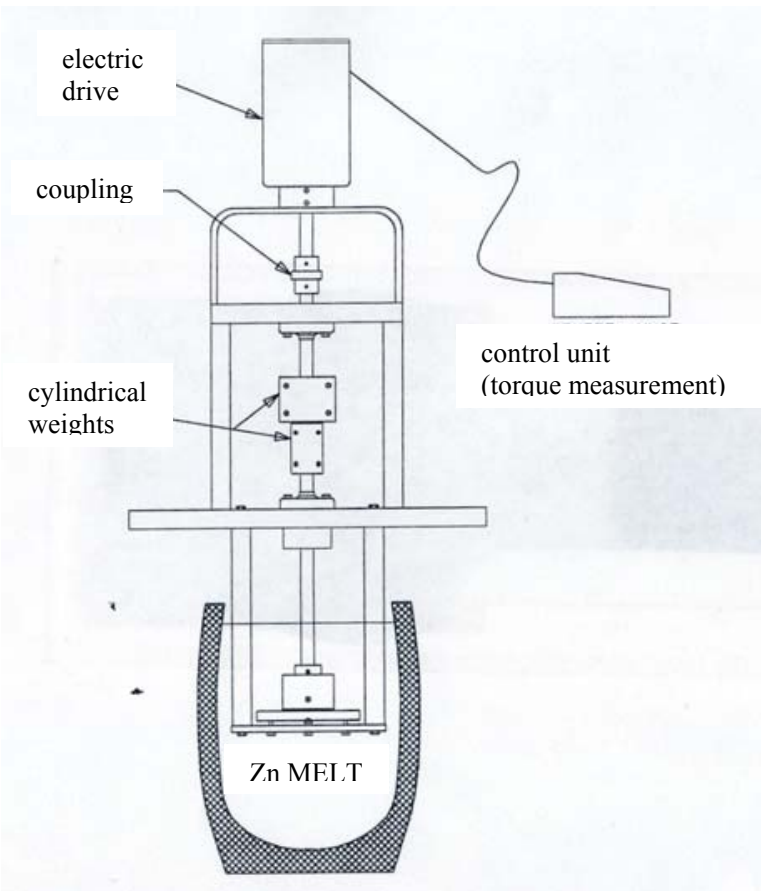

\section{Figure 2.2: Diagram of Teck Cominco's Test Apparatus}

Materials used in Teck Cominco's study include the following: 316 S.S., Inconel 718, Mild Steel with Alloy, 316 S.S., Stellite \#6, Chromium Oxide coating, Tungsten Carbide coating, and Chromium Oxide lubricated. The testing showed that the friction coefficient of these materials ranged from 0.195 to 0.41 . Figure 2.3 shows the results of Teck Cominco's friction coefficient testing [6]. The pin on disc wear of the material showed that wear was measurable [6], but in most cases insignificant, as seen in Table 2.1. 


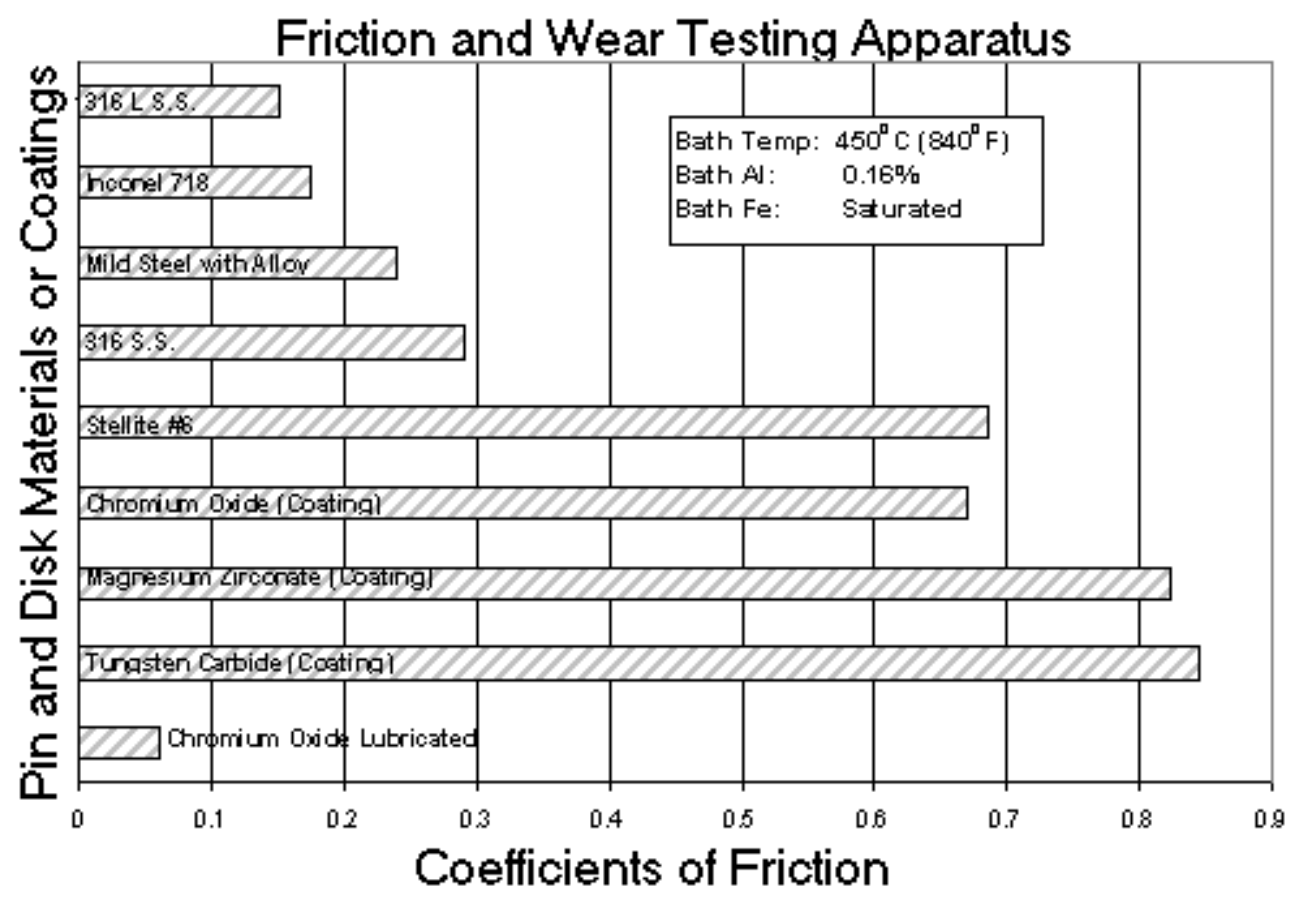

Figure 2.3: Teck Cominco's Friction Coefficient Data of Pin and Disc Materials

Table 2.1: Results from Teck Cominco's Wear and Friction Testing

Test Conditions: Bath Composition: $0.20 \% \mathrm{Al}, 0.0016 \% \mathrm{Fe}$

Melt Pot Temperature: $470^{\circ} \mathrm{C}$

\begin{tabular}{|l|l|l|l|l|}
\hline Plate Material & Pin Material & $\begin{array}{l}\text { Coef. of Friction } \\
(\mu)\end{array}$ & $\begin{array}{l}\text { Plate Wear } \\
(\mathbf{i n})[\mathbf{m m}]\end{array}$ & $\begin{array}{l}\text { Pin Wear } \\
(\mathbf{i n})[\mathbf{m m}]\end{array}$ \\
\hline Stellite \#6 & Stellite \#6 & 0.29 & -- & $0.0009[0.023]$ \\
\hline Stel. \#6 with Graphite & Stellite \#6 & 0.36 & -- & $0.0005[0.013]$ \\
\hline Stel. \#6 with Graphite* & Stellite \#4 & 0.23 & -- & -- \\
\hline Tribaloy T-800 & Stellite \#4 & 0.39 & -- & $0.0003[0.008]$ \\
\hline Triabaloy T-800 & Stellite \#4 & 0.37 & -- & $0.0005[0.013]$ \\
\hline AmZirOx 86 & AmZirOx 86 & 0.40 & $0.001[0.025]$ & $* *$ \\
\hline AmZirOx 86 & Stellite \#4 & 0.37 & Light scoring & -- \\
\hline SIALON & Stellite \#4 & 0.59 & -- & $0.0004[0.010]$ \\
\hline SIALON*** & Stellite \#4 & 0.41 & -- & $0.0005[0.013]$ \\
\hline
\end{tabular}

* Plate surface coated with graphite lubricant spray prior to test.

** Pin wear not measured, pins fractured on removal from test rig.

*** Sialon plate polished to ensure flat surface.

In order to evaluate the attack by the molten zinc alloy, a static immersion test was used [7]. The samples were weighed before and after into the zinc pot to determine 
loss per unit area. As seen in Table 2.2 the loss per unit area ranged from $0.7 \mathrm{~g} / \mathrm{dm}^{3}$ to $32.8 \mathrm{~g} / \mathrm{dm}^{3}$.

Table 2.2: Teck Cominco's Static Immersion Tests

Test Conditions: Zinc alloy: $\mathrm{Zn}+0.2 \% \mathrm{Al}+0.022 \% \mathrm{Fe}$

Temperature: $470^{\circ} \mathrm{C}$

Time: 96 Hours

\begin{tabular}{|c|c|}
\hline Material & Loss / Unit Area (g/dm $\left.{ }^{2}\right)$ \\
\hline AmZirOx86 & $*$ \\
\hline SIALON & $*$ \\
\hline Tribaloy T-800 & 0.7 \\
\hline Stellite \#6 & 1.9 \\
\hline Inconel 718 & 2.5 \\
\hline 316L S.S. & 2.8 \\
\hline Mild Steel & 32.8 \\
\hline
\end{tabular}

The main conclusion drawn from Teck Cominco's submerged zinc pot hardware research was that metallic materials reacted with the bath to form intermetallics. The formation of intermetallics was shown to be dependent on zinc composition and zinc pot temperature. The formation of intermetallics also affects the friction and wear of the material. Teck Cominco found that aluminum in the zinc composition had a strong effect on friction and wear, while lead and antimony had no effect.

Next, Teck Cominco designed and built a testing machine to simulate actual steel mill galvanizing line conditions. The Teck Cominco full journal-bearing tester is capable of testing full size stabilizer rollers of half size sink roll bearings. In the machine design a motor and shaft supports a hollow drive shaft inclined at 30 degrees from horizontal. The test specimen is secured to the end of the drive shaft with a tapered fit. A tension compression load cell is used to measure the bearing load provided by a hydraulic system. A heated zinc pot sits below the test bearing and is raised into position by a hydraulic stacker. 
The wear tests were performed under typical galvanizing line operating conditions. "The bushings used for testing the liquid zinc were modified by giving them larger clearance on their unloaded side so that experimental work was facilitated. Four tests were run with the low-load air cylinder to examine hydrodynamic operation and one test with the hydraulic cylinder, fully testing the capabilities of the apparatus. Significant zinc attack was seen on all materials after testing. In one case dross was encouraged to enter the bearing clearance by allowing the bath level to drop to the clearance height allowing dross entry. This was found to give particularly severe wear. In general this apparatus appears to be well suited for simulation of pot hardware bearing operations as they happen on sheet galvanizing lines." The results of the zinc attack on both 316L stainless steel and Stellite \#6 can be seen in Tables 2.3 and 2.4 respectively.

Table 2.3: Results of EDS Analysis on the Alloy Layers of the 316L Bushing

\begin{tabular}{|l|l|l|l|l|l|l|l|}
\cline { 2 - 8 } \multicolumn{1}{c|}{} & \multicolumn{6}{c|}{ Elements Analyzed (Normalized wt\%) } \\
\hline Probe Location & Zn & Fe & Al & Cr & Ni & Mo & Si \\
\hline Surface crystal particle (A) & 92.4 & 5.2 & 1.8 & 0.3 & 0.4 & --- & -- \\
\hline Upper amorphous layer (B) & 87.2 & 6 & 3.6 & 0.6 & 0.6 & 1.4 & 0.5 \\
\hline Lower amorphous layer (C) & 73.8 & 13.4 & 9.1 & 1 & 0.9 & 1.2 & 0.6 \\
\hline Interface line (D) & 59.8 & 20.4 & 15 & 1.5 & 1.3 & 1.3 & 0.8 \\
\hline Stainless steel substrate & --- & 71.5 & --- & 14.7 & 12.2 & 1.3 & 0.4 \\
\hline
\end{tabular}

Table 2.4: Results of EDS Analysis on the Alloy Layers of the Stellite \#6 Sleeve

\begin{tabular}{|l|l|l|l|l|l|l|l|}
\cline { 2 - 9 } \multicolumn{1}{c|}{} & \multicolumn{6}{c|}{ Elements Analyzed (Normalized wt\%) } \\
\hline Probe Location & Zn & Co & Fe & Cr & W & Al & Mo \\
\hline Surface crystal particle (A) & 94.5 & 3.1 & 2.1 & 0.4 & --- & --- & --- \\
\hline Alloy layer (B) & 79.2 & 8.9 & 2.9 & 2.2 & 4.4 & 2.5 & --- \\
\hline Stellite dendrite structure & --- & 76.6 & 2.6 & 19.6 & 0.8 & --- & 0.4 \\
\hline Stellite inter-dendritic structure & --- & 18.2 & 1 & 79.3 & 1 & --- & 0.5 \\
\hline
\end{tabular}




\subsection{WVU's Lubricity Research and Testing Apparatus}

In 1998, during a methanol fueled gas turbine test at West Virginia University, the fuel controller bearings seized. This indicated the need for an additive to improve methanol lubricity properties. Many fuel additives for the methanol auto racing industry were available on the market. In order to minimize operational costs associated with adding fuel lubricant, a new friction test apparatus was designed to measure the friction coefficient of the bearing materials used in the GTC-85 gas-turbine fuel controller with various additives. Fuel additive cost was based on required concentration multiplied by cost per gallon. The minimum concentration required was defined so as to equalize bearing friction inside methanol to that of kerosene or Jet-A aviation grade kerosene. A new apparatus was designed, in order to eliminate the vibrations and erratic data produced by the existing WVU wear testing apparatus. The objective of that research was to find the most cost effective fuel additive for methanol capable of providing lubricity equal or better than that of jet fuel.

The new testing apparatus at WVU was designed to operate at typical gas-turbine bearing pressures by using a dead weight attached to the spindle, as seen in Figure 2.4. The spindle transferred the load to a disk containing three balls, which rotated on a fixed plate. A ball bearing was installed on the centering pin in the center of the fixed plate to insure that the disk rotates smoothly about its axis. To maintain constant RPM during the test, a vertical mill with variable speeds was used as a driver. 


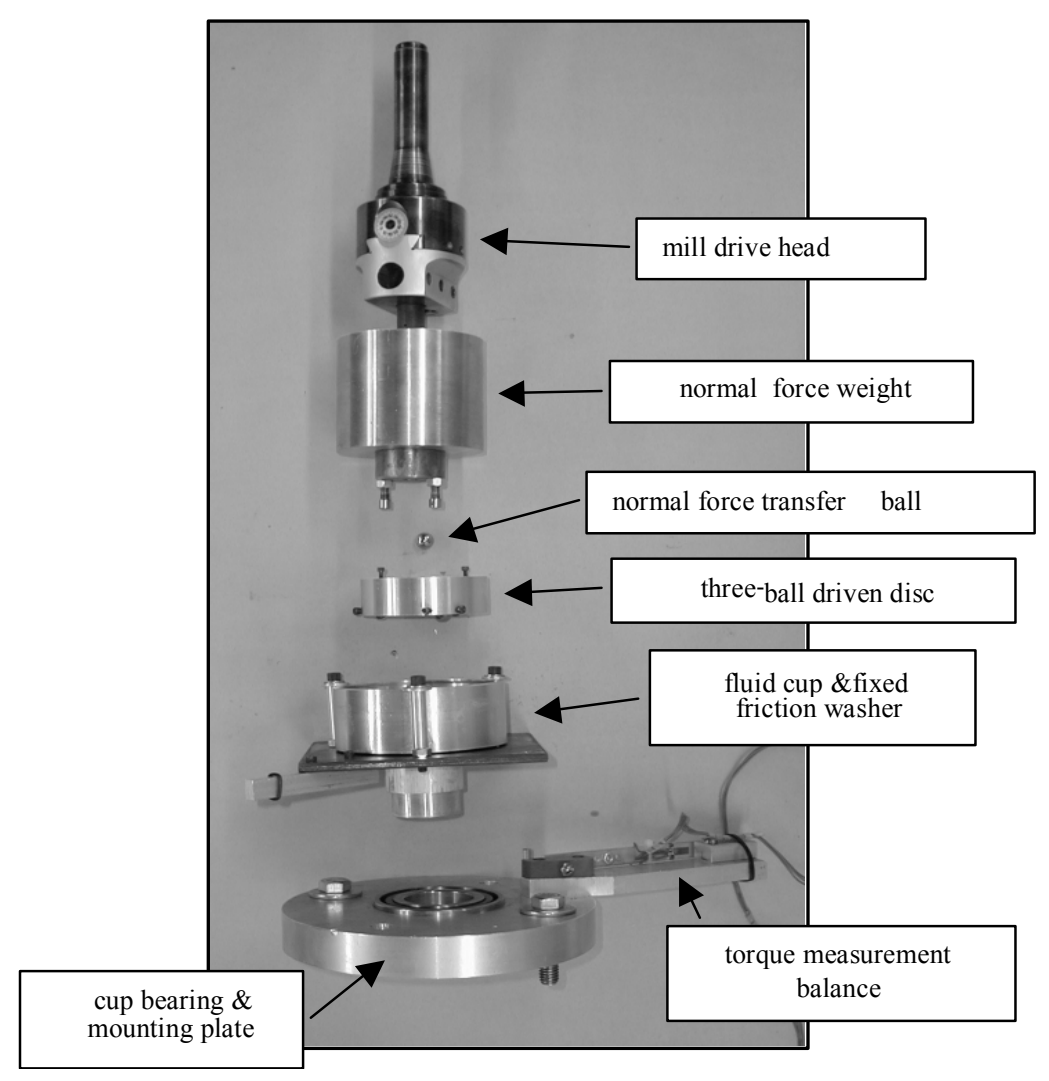

Figure 2.4: WVU Lubricity Test Apparatus

Torque is transferred from the drive shaft to the $6 \mathrm{lb}_{\mathrm{f}}$ dead weight by use of a horizontal shear pin. From that pin via two vertical pins to the rotating 0.5 inch ball holder. A cup filled with methanol and fuel additive contains a ground washer on which the three balls rotate. The three balls had flat contact surfaces ground on them to reproduce recommended contact pressures for bronze bearings. The torque was measured with a beam type load cell.

Each run of the test apparatus was for 10 minutes at $3.5 \%$ of a lubricated bearing design load and provided repeatable data. Compared to the previously available WVU test equipment, this apparatus showed significant improvement. Table 2.5 shows typical 
friction coefficients for various materials from the Machinery's Handbook [8]. Table 2.6 shows the fuel calibration test results for methanol fuel and for Jet A, the standard gas turbine fuel.

Table 2.5: Machinists Handbook Friction Coefficients

\begin{tabular}{|c|c|}
\hline System & Friction Coefficient \\
\hline Metal on Metal (Dry) & $0.15-0.20$ \\
\hline Metal on Metal (Wet) & 0.3 \\
\hline Occasionally Greased & $0.07-0.08$ \\
\hline Continuously Greased & 0.05 \\
\hline Mild Steel on Brass & 0.44 \\
\hline
\end{tabular}

Table 2.6: Results of WVU's Friction Coefficient Test Apparatus

\begin{tabular}{|c|c|}
\hline System & Friction Coefficient \\
\hline LPMEOH $^{\mathrm{TM}}$ Methanol (Mild Steel on Brass) & 0.309 \\
\hline Jet A (Mild Steel on Brass) & 0.167 \\
\hline
\end{tabular}

Based on the effects of fuel additives on friction coefficient, shown in Figure 2.5, it was decided to continue operation of the gas turbine on methanol, but with $0.2 \%$ of a commercial fuel additive.

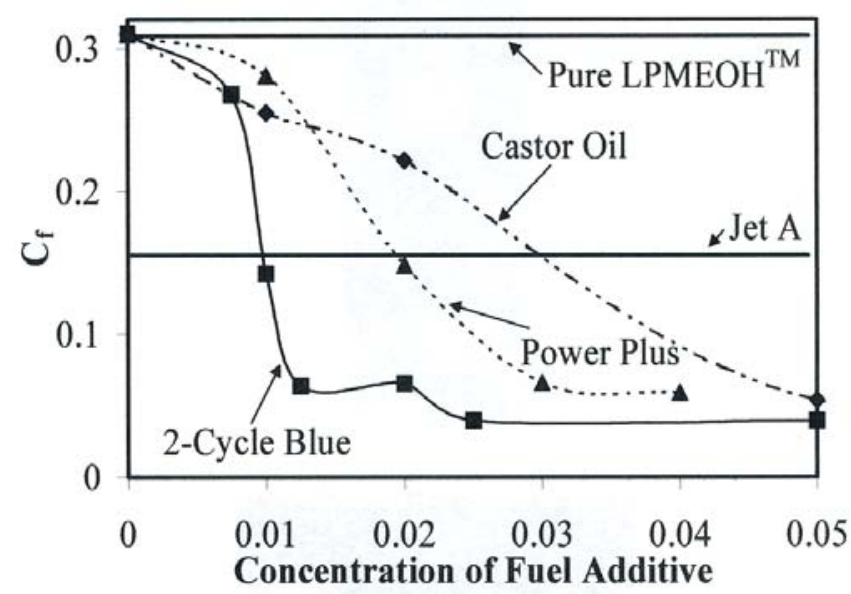

Figure 2.5: Effect of Fuel Additives on Friction Coefficient 


\subsection{Zinc Pot Bearing Material Research}

The primary reason for galvanizing line stoppage is zinc pot bearing wear and associated line vibrations, which effects the appearance of the galvanized sheet, or create problems with steering the sheet. A case study performed by (Zoz, et, al [9]) shows the advantage of replacing common bearing materials with advanced materials and coatings. Stellite \#6 is a common bearing material that has poor physical lubricating properties but, is corrosion resistant and does not contribute to dros build-up. Zoz used various materials for testing made of Stellite-4 powder with two different alloying elements, $A+B$, under each of 3 different parameter settings, 1-3, shown in Figure 2.6. A process control agent had to be added for the use of alloying element B. The test required test samples were made by Hot Isostatic Pressing (HIP) (El-Madg et, al [10]) using powder consolidation. Ten new material Stellite samples were consolidated into test specimens. To evaluate the wear behavior of these samples, Zoz, et, al [9] designed a cylinder and bush test apparatus (CIBA). 




Figure 2.6: Flow Chart of Powder Production by Hot Isolated Pressing [9]

Zoz, et, al describes the CIBA as follows: "The inner part of the bearing system (bush fixed on the rolls) is simulated by the bulk sample itself (cylinder), carrying the new materials as well as the reference material. The outer part of the bearing (bush) is simulated by real Stellite counter-bearing parts." The bush is lowered into a zinc bath, then loaded and rotated against the cylinder, by a drilling machine, to simulate wear in hot dip galvanizing line processes.

The CIBA experiments have shown better wear resistibility in the bearing test samples than in operating galvanizing lines. Also, any dependency between hardness and abrasion resistance was not observed. The test samples did not show any cracks, inclusions, hollows, or binding failures in the diffusion zone between inner cylinder and consolidated material. 
There are many types of commercially available composite coatings; the most popular of which is tungsten carbide (WC). These materials can be laser cladded on a variety of base materials including stainless steel and ORNL 4. In Surface and Coatings Technology Journal are articles describing the effects of tungsten carbide laser coatings submerged in zinc. Laser surface cladding (Seong, et, al [11]) is capable of producing a wide range of surface alloys and composites based on desired properties. "Application of the laser beam cladding surface engineering [11] allows to obtain porosity and crack free surface clads containing uniformly distributed hard particles in the softer and tough matrix." The structure of tungsten carbide laser cladding depends on the correct selection of the laser processing parameters to achieve porosity and crack free WC-metal composite coatings.

Studies have been done that look at the effects of molten zinc reacting with the tungsten carbide coating. Understanding the coating degradation processes [11] is very important for the development of better coatings for CGL pot rolls. WC-Co coating usually does not exceed 100 days. Dross build up on the zinc rollers degrades coating quality.

Experiments have been conducted (Seong, et, al [11]) in which rollers have been immersed in molten zinc to examine the effects of zinc attack on the coating. Dozens of dross specimens were collected for comparisons of reaction products and were analyzed with a scanning electron microscope and energy disperse spectrum. The experiments determined that aluminum in molten zinc reacted with the coating layer along cracks and diffused into the coating with similar diffusion depths. 
Various companies have measured the friction coefficient and wear of submerged zinc pot roller bearings in molten zinc. This was in an effort to help design better test rigs and apparatus. Tests have proven that the temperature of the molten zinc has a strong effect on bearing materials and coatings. The zinc composition used can break down the structure of the bearing material and coating. It was discovered that materials with the best wearing properties may not have the lowest friction coefficient.

Research has been done to determine the effects of the molten zinc on the bearing materials. Static immersion tests were done to show how materials and coatings react with zinc. New zinc bath compositions have been researched for the best reaction with the bearing materials and coatings. Bearing materials like Stellite \#6 and tungsten carbide coatings have been found to provide long lasting bottom roller bearing materials.

\subsection{Arcelor Research's Bearing Tester for Bath Hardware Material}

Arcelor Research developed an apparatus to measure friction coefficient and wear of zinc pot bearing materials. "Friction and wear [12] of sleeves and bushings is a main concern for Galvanizers, and cause: poor rotation quality, poor product quality, lowering of line speed, unexpected line stops, and high cost maintenance stops." The objective of the study at Arcelor is to determine the influence of sleeves/bushing friction phenomenon exactly as in an industrial zinc pot and to obtain results that are usable by industrial galvanizing lines.

The apparatus designed for testing zinc pot bearing materials used the same applied force and rotation speed as in industrial lines. The tester was capable of applied forces up to $50,000 \mathrm{~N}$ and rotation speeds up to $160 \mathrm{~m} / \mathrm{min}$. A $1000 \mathrm{~kg}$ controlled 
temperature zinc pot with chemical analysis was used, as seen in Figure 2.7. The apparatus used a 150-mm sleeve, shown in Figure 2.8, to simulate the zinc pot bottom bearing rollers.

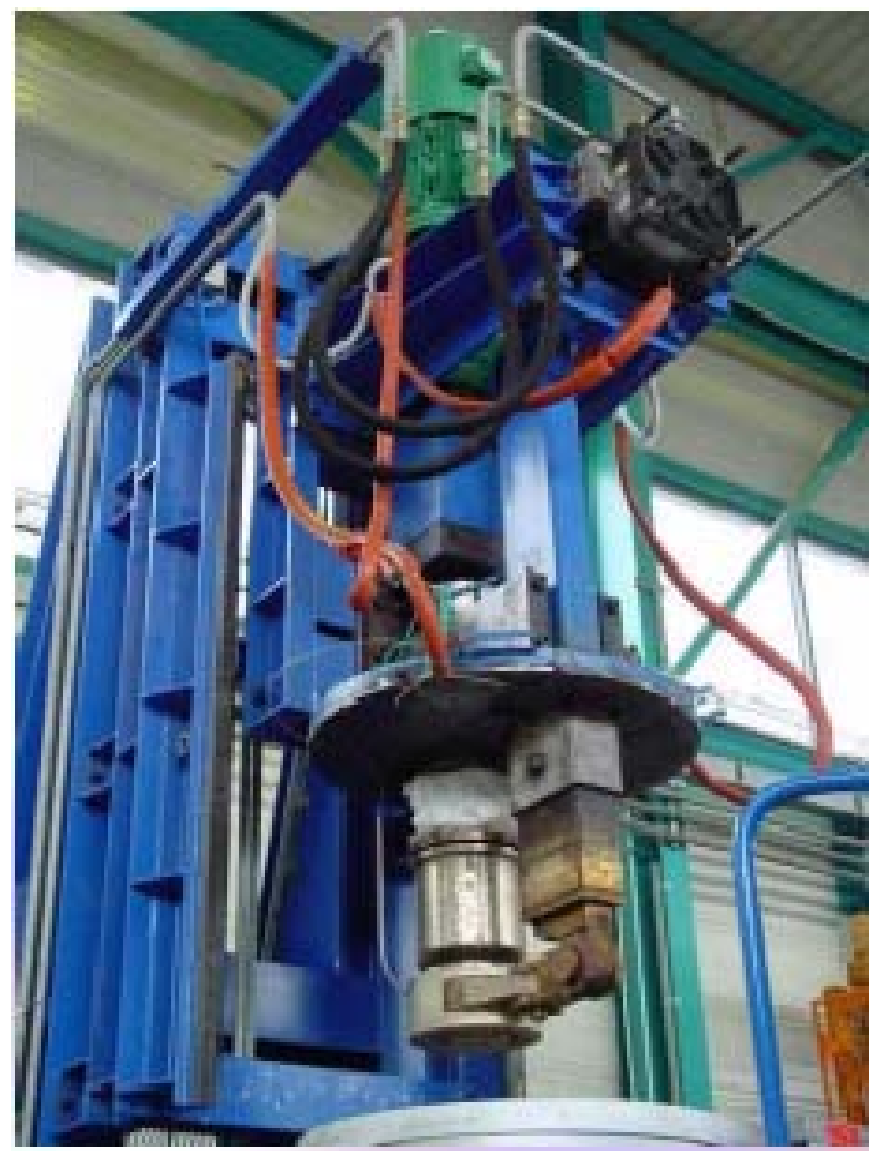

Figure 2.7: Picture of Arcelor's Test Apparatus 


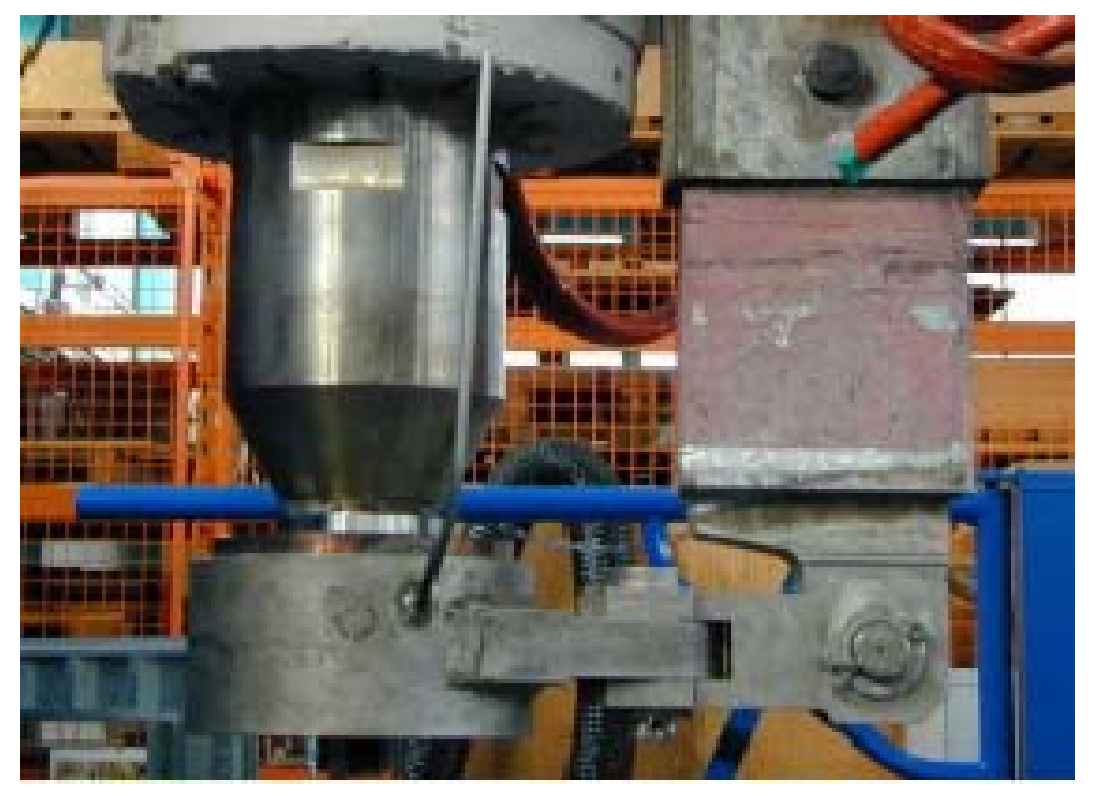

Figure 2.8: Picture of Arcelor's Test Specimen

Arcelor's test apparatus has the ability to measure applied force, rotation speed, and bath and bearing temperatures. This machine can also measure friction torque and wear by use of a position sensor. Tests were run for 4 days at an equivalent line speed of $120 \mathrm{~m} / \mathrm{min}$ and $24,000 \mathrm{~N}$ force for Stellite \#6 on Stellite \#6. Friction torque and wear data were collected and used to calculate friction coefficient. The friction coefficient and wear as a function of time can be seen in Figures 2.9 and 2.10 respectively. 


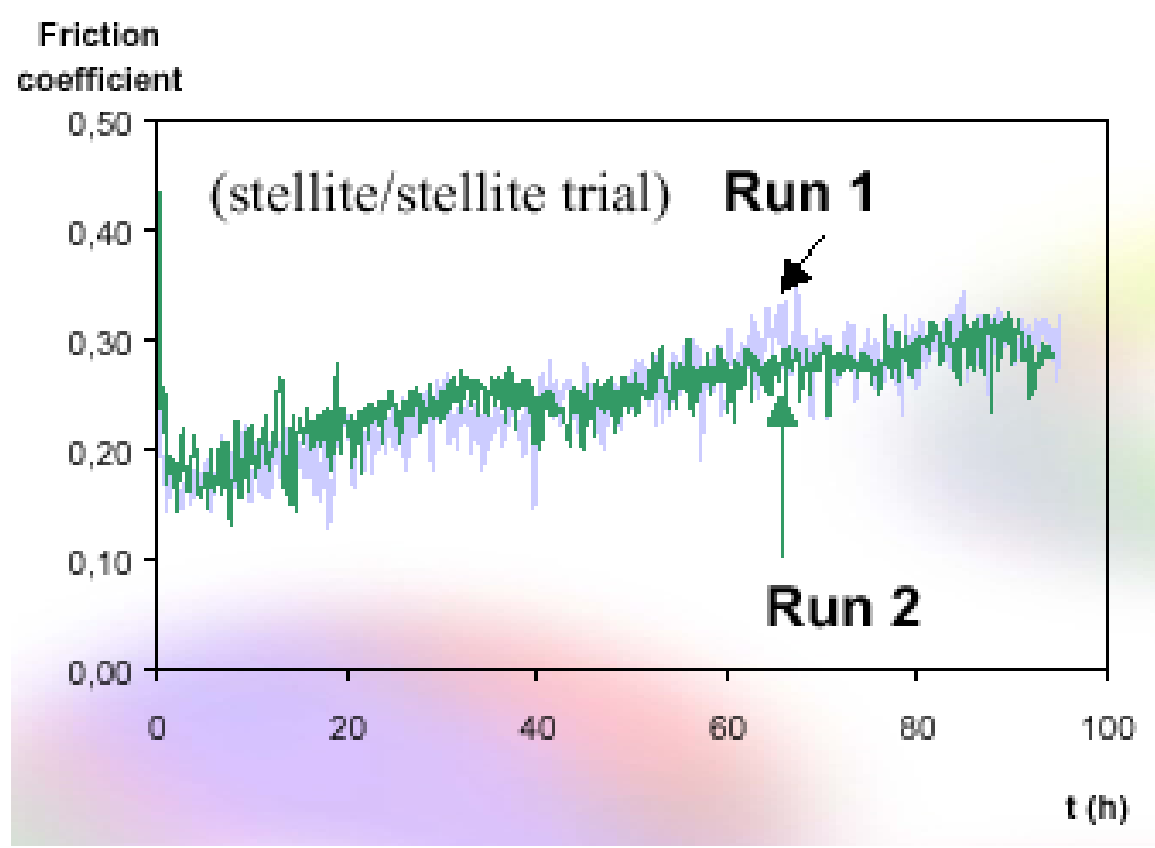

Figure 2.9: Friction Coefficient as a Function of Time for Stellite \#6 on Stellite \#6 in Arcelor's Tester [12]



Figure 2.10: Wear as a Function of Time for Stellite \#6 on Stellite \#6 in Arcelor's Tester [12]

Arcelor's test run indicates that the wear of Stellite \#6 on Stellite \#6 is linear with time. Figure 2.11 shows that at different bearing loads the wear as a function of time remains linear. The friction coefficient calculations indicated that the coefficient became 
constant only after long periods of time. A friction coefficient of 0.14 was determined after 3 hours of testing, but a friction coefficient of 0.30 was determined after 4 days of testing as seen in Figure 2.12. This may be caused by the time required to properly "seat" the bearing surfaces.

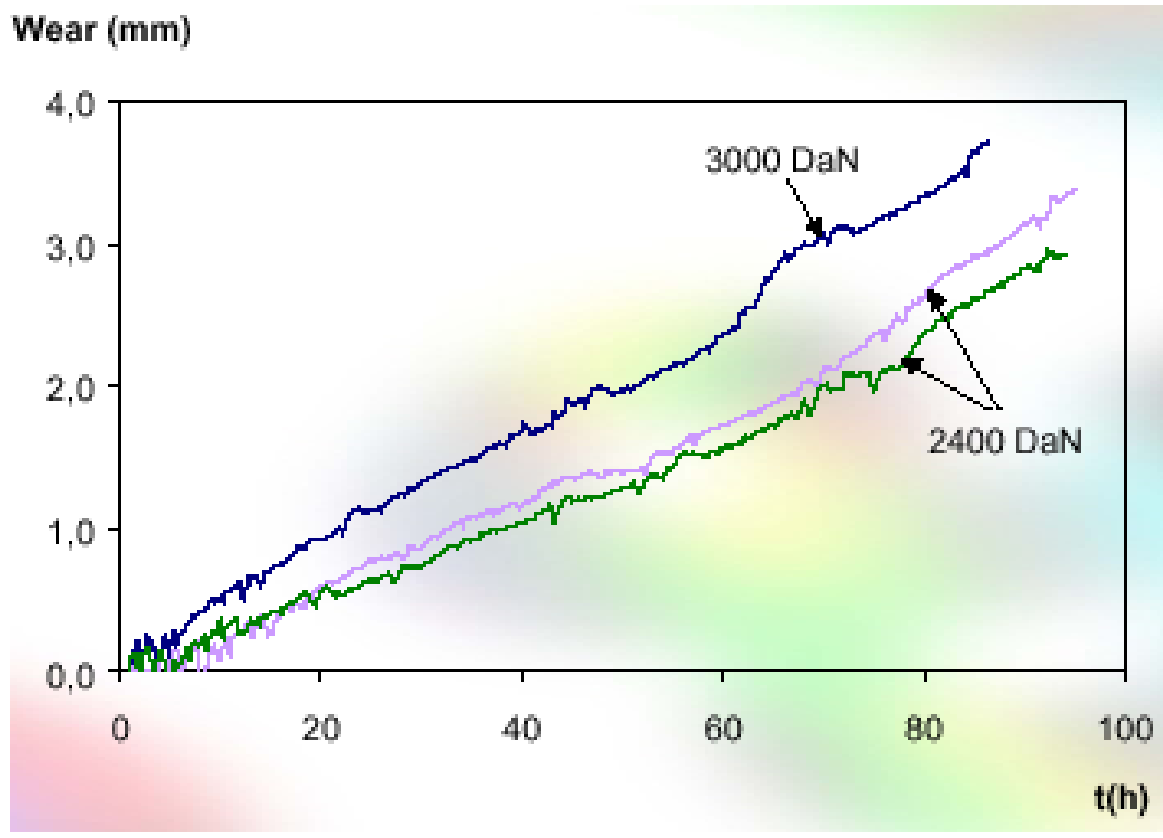

Figure 2.11: Wear as a Function of Time at Different Applied bearing Loads for Stellite \#6 on Stellite \#6 [12] 


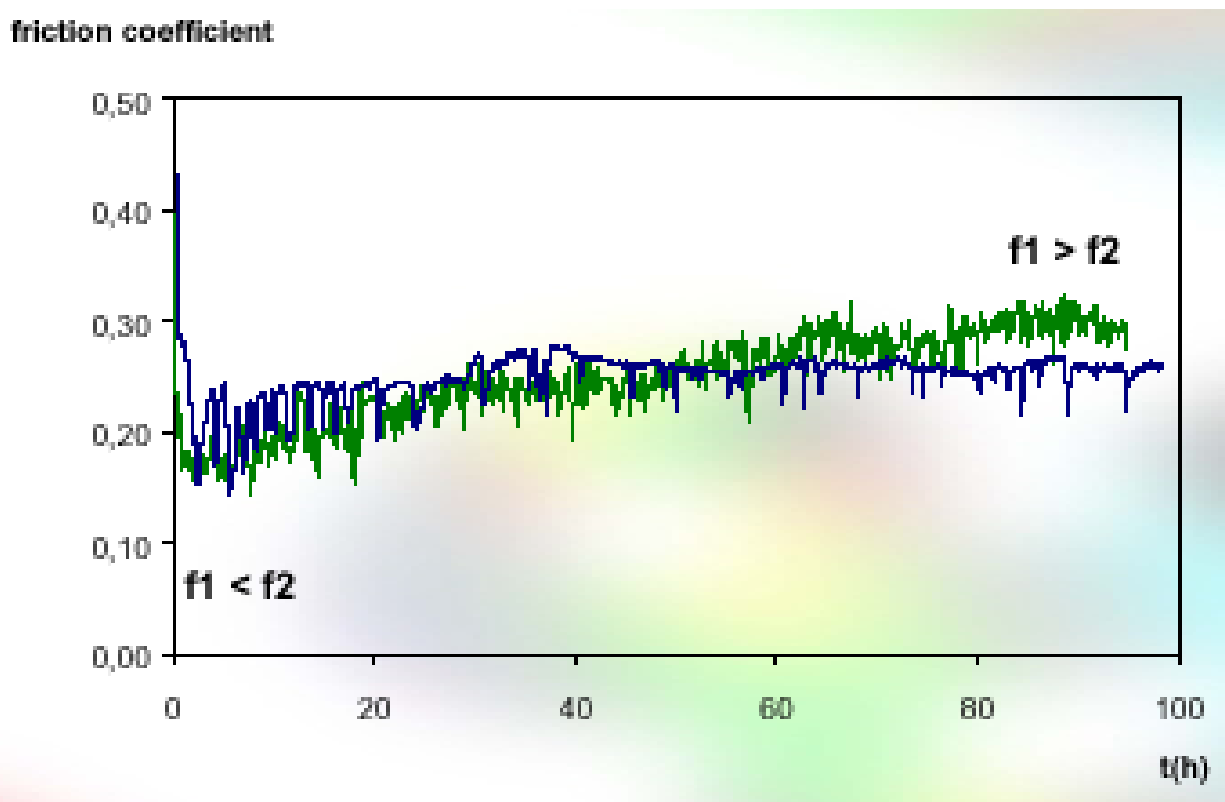

Figure 2.12: Evolution of Friction Coefficient with Time for Stellite \#6 on Stellite \#6 [12]

\subsection{WVU's Zinc Pot Bearing Materials Tester}

A new machine designed specifically for testing zinc pot bearing materials was developed at West Virginia University by Dr. John Loth and Ryan Ware [13]. The design objectives were:

a) Provide repeatable friction coefficient and material wear data for bearing material comparison.

b) Minimize cost to prepare, install, and analyze test samples.

c) Test sample geometry selected was a 1-inch ball surface mounted on a spindle, which rotates on a stationary sample, with a narrow seat machined into it, at a $45^{\circ}$ contact angle.

d) Automate data acquisition by using high sampling rate.

e) Provide pneumatic cushioning of the stationary sample so as to eliminate vibration and load changes and simplifying load adjustment. 
f) Use small stainless steel cups, within each is mounted a stationary sample. The cup is then filled with zinc taken from an actual zinc pot.

g) Use an inexpensive vertical mill to drive a water-cooled spindle containing the 1-inch hemisphere test sample.

This apparatus was designed to simulate actual steel mill galvanizing line machine bearing operating conditions, as shown in Figure 2.13 and Table 2.7. These typical steel mill galvanizing line operating conditions were provided by Weirton Steel.

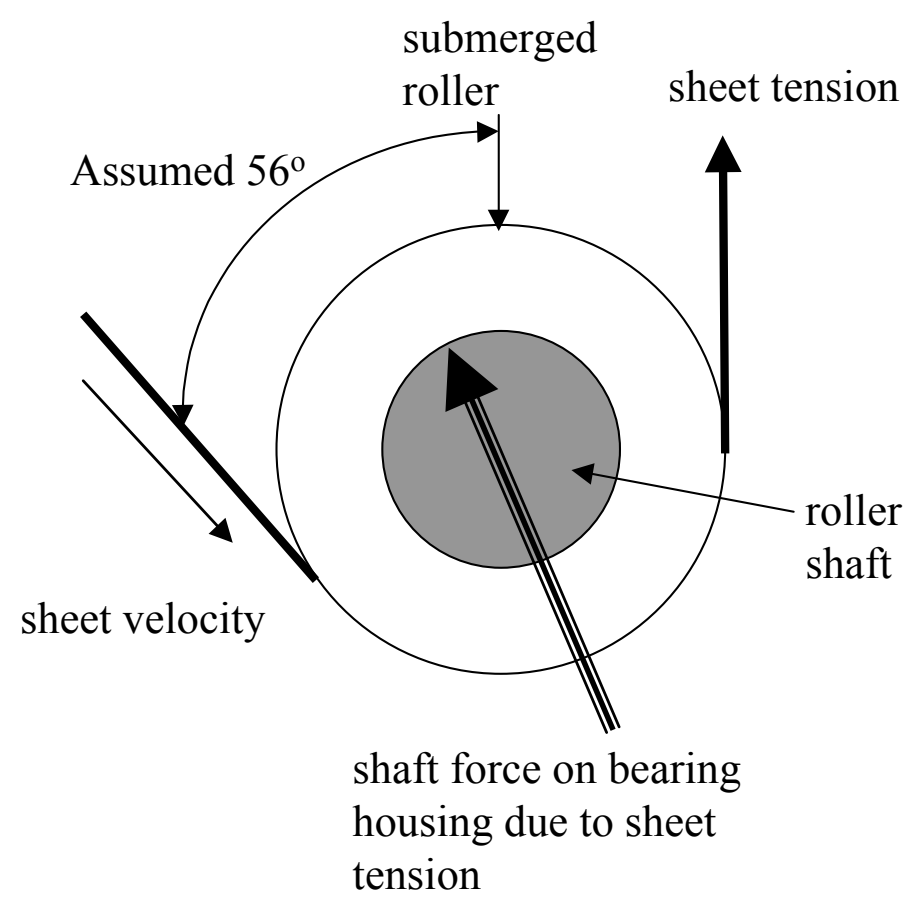

Figure 2.13: Schematic of Galvanizing Line Roller and Bearing 
Table 2.7: Weirton Steel Operational Galvanizing Lines Data Ranges

\begin{tabular}{|c|c|c|c|}
\hline & Line \#3 & Line \#4 & Line \#5 \\
\hline Pot liner & Ceramic Brick & Ceramic Brick & Ceramic Brick \\
\hline Zinc pot chemistry & $0.08-0.22 \% \mathrm{Al}$ & $0.15-0.22 \% \mathrm{Al}$ & $0.08-0.22 \% \mathrm{Al}$ \\
\hline Temperature & $880-1100^{\circ} \mathrm{F}$ & $900-940^{\circ} \mathrm{F}$ & $880-900^{\circ} \mathrm{F}$ \\
\hline Sheet width & $24-49$ inch & $24-42$ inch & $24-49$ inch \\
\hline Sheet thickness & $.028-.165$ inch & $\begin{array}{l}.0094-.028 \\
\text { inch }\end{array}$ & $.012-.045$ inch \\
\hline Sheet tension $\left(T_{s}\right)$ & $3200-5000 \mathrm{lbf}$ & $1000-2000 \mathrm{lbf}$ & $3200-4800 \mathrm{lbf}$ \\
\hline Sheet velocity & $50-300 \mathrm{ft} / \mathrm{min}$ & $100-410 \mathrm{ft} / \mathrm{min}$ & $110-550 \mathrm{ft} / \mathrm{min}$ \\
\hline \multicolumn{4}{|c|}{ Bottom Roller Characteristics } \\
\hline Bearing life & $7-14$ days & $7-14$ days & 7 - 30 days \\
\hline Bearing materials & 316L S.S. & 316L S.S. & 316L S.S \\
\hline Outside diameter $\left(D_{R}\right)$ & 24 inch & 20 inch & 20 inch \\
\hline Shaft diameter $\left(D_{B}\right)$ & 5.25 inch & 3.875 inch & 3.875 inch \\
\hline  & 4 inch & 4 inch & $\begin{array}{l}4 \text { inch, three 1- } \\
\text { inch inserts }\end{array}$ \\
\hline $\begin{array}{l}\text { Each bearing has } \\
\text { projected area }\left(A_{B}\right)\end{array}$ & 21 inch $^{2}$ & 15.5 inch $^{2}$ & 9.65 inch $^{2}$ \\
\hline
\end{tabular}

To correlate Weirton Steel operational data to the WVU zinc pot bearing material tester, an average sheet entry angle of $56^{\circ}$ from vertical was assumed. From the configuration shown in Figure 2.13, each of the two bearings at the end of the roller carries a load $\mathrm{F}_{\mathrm{B}}$ related to the sheet tension, $\mathrm{F}_{\text {sheet }}$, by:

$$
F_{B}=T_{S} *\left[\left(\cos \left(0.5^{*} 45^{\circ}\right)\right]=0.88^{*} T_{S}\right.
$$

The bearing contact pressure was determined by a ratio of bearing force, $\mathrm{F}_{\mathrm{B}}$, over the contact area of one of the two bearings. 


$$
P_{B}(p s i)=\frac{F_{B}}{A_{B}}=0.88 *\left(\frac{T_{S}}{A_{B}}\right)
$$

The bearing contact velocity is lower than the sheet velocity, which equals the roller surface velocity.

$$
V_{B}=V_{\text {Sheet }} *\left[\frac{D_{B}}{D_{\text {Roller }}}\right]
$$

With the use of equations 2.1 through 2.3 steel mill bearing pressures and velocities were determined. Table 2.8 shows the velocity of the bearing and the bearing pressure in the zinc pot galvanizing lines.

Table 2.8: Correlation Between Steel Mill and Tester Operating Conditions

\begin{tabular}{|l|c|c|c|}
\hline & Line $\mathbf{\# 3}$ & Line \#4 & Line \#5 \\
\hline $\begin{array}{l}\text { Projected Contact Area of } \\
\text { Each Bearing, } \mathrm{A}_{\mathrm{B}}\left(\text { inch }^{2}\right)\end{array}$ & 21 & 15.5 & 9.65 \\
\hline Line Speed $(\mathrm{ft} / \mathrm{min})$ & $50-300$ & $100-410$ & $110-550$ \\
\hline Line Tension, $\mathrm{T}_{\mathrm{S}}\left(\mathrm{lb}_{\mathrm{f}}\right)$ & $3200-5000$ & $1000-2000$ & $3200-4800$ \\
\hline Bearing contact $\mathbf{V}_{\mathbf{B}}(\mathbf{i n c h} / \mathbf{s})$ & $2.19-13.1$ & $3.88-15.9$ & $4.26-21.3$ \\
\hline Bearing contact $\mathbf{P}_{\mathbf{B}}(\mathbf{p s i})$ & $134-210$ & $57-114$ & $293-440$ \\
\hline
\end{tabular}

West Virginia Universities' zinc pot bearing materials tester uses a 1 inch ball rotating on a stationary seat, machined as shown in Figure 2.14. This design is based on a $45^{\circ}$ average contact angle or mean contact diameter of 0.707 inches. The $5 / 8$-inch hole in the seat results in an outer diameter of 0.780 -inches. This is fabricated by sinking a 1 inch ball mill to the depth of 0.187 -inches. The resulting horizontal projected area $\mathrm{A}_{\mathrm{hor}}=$ 0.171 square inches. 


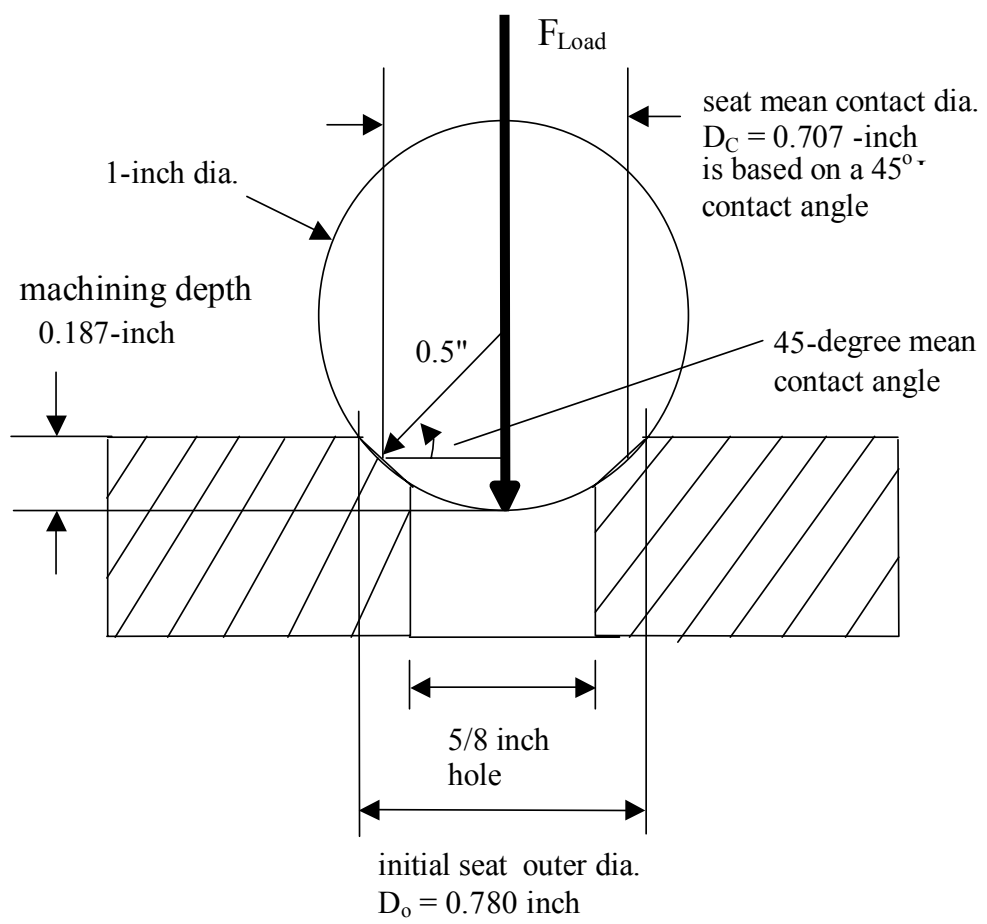

Figure 2.14: Ball and Seat Specimen Diagram

In order to duplicate steel mill operating bearing pressures, $P_{B}(p s i)$, in the bearing materials tester the ball specimen containing spindle was loaded to $\mathrm{F}_{\text {Load }}$ to produce the desired bearing contact pressure, $\mathrm{P}_{\mathrm{c}}$.

$$
P_{B}=P_{C}=\frac{F_{\text {Load }}}{A_{\text {Hor }}=0.171}=\frac{F_{\perp}}{A_{\text {Seat }}}
$$

Based on the 0.780-inch seat outer diameter, the contact velocity for the sample specimens was determined.

$$
\text { Ball RPM }=V_{C}(\text { inch } / s) *[60 /(0.707 * \pi)=27]=V_{C}(f t / s) * 324
$$

With the use of the above equations the operational data ranges provided by Weirton Steel were converted to equivalent operational ranges for WVU's bearing materials tester, as shown in Table 2.9. 
Table 2.9: Weirton Steel Operational Ranges Converted to WVU's Zinc Pot Bearing Materials Tester (* operating conditions are common to both)

\begin{tabular}{|c|c|c|c|}
\hline & Line \#3 & Line \#4 & Line \#5 \\
\hline Line Speed $(\mathrm{ft} / \mathrm{min})$ & $50-300$ & $100-410$ & $110-550$ \\
\hline Line Tension $(\mathrm{lb})$ & $3200-5000$ & $1000-2000$ & $3200-4800$ \\
\hline${ }^{*}$ Bearing contact $\mathbf{V}_{\mathbf{C}}(\mathbf{i n c h} / \mathbf{s})$ & $\mathbf{2 . 1 9}-\mathbf{1 3 . 1}$ & $\mathbf{3 . 8 8}-\mathbf{1 5 . 9}$ & $\mathbf{4 . 2 6}-\mathbf{2 1 . 3}$ \\
\hline${ }^{*}$ Bearing contact $\mathbf{P}_{\mathbf{B}}(\mathbf{p s i})$ & $\mathbf{1 3 4}-\mathbf{2 1 0}$ & $\mathbf{5 6 . 8}-\mathbf{1 1 4}$ & $\mathbf{2 9 2}-\mathbf{4 3 8}$ \\
\hline Tester Ball RPM & $59.3-365$ & $34.3-429$ & $117-575$ \\
\hline Tester Ball Load $(\mathrm{lb})$ & $23-36$ & $9.71-19.4$ & $50-74.9$ \\
\hline
\end{tabular}

A vertical mill/drilling machine was used to drive WVU's zinc pot bearing materials tester. This machine provides the constant RPM and load needed. A 2500-Watt melting pot was used to melt and maintain tin to the desired temperature. The outside dimensions of the zinc pot are 10-inch diameter by 10-inch tall, with inside dimensions 6inch diameter by 6-inch height. The 1/4-inch aluminum disc covering the pot is suspended on a 1/4-inch diameter ball bearing track. This disc supports the cup holder. The friction torque transmitted from the spindle to the ball seat inside the zinc containing cup is transferred via the cup holder to the disc. A bracket attached to this disc transfers this torque to a strain gage beam, connected to the data logger. The water-cooled aluminum ring with the $1 / 4$-inch ball bearing track is attached to three $3 / 4$-inch linear bearings, which allow it to move up and down friction free. The ring rests on a PVC plate floating on an inner tube, as shown in Figure 2.15. The tube in turn rests on another plate supported by three load measuring strain gage balances. Two of these are used for a digital load indicator, while the third gage is used for computer data logging. Figure 2.16 shows a picture of the bearing track assembly and cup torque transfer plate. 


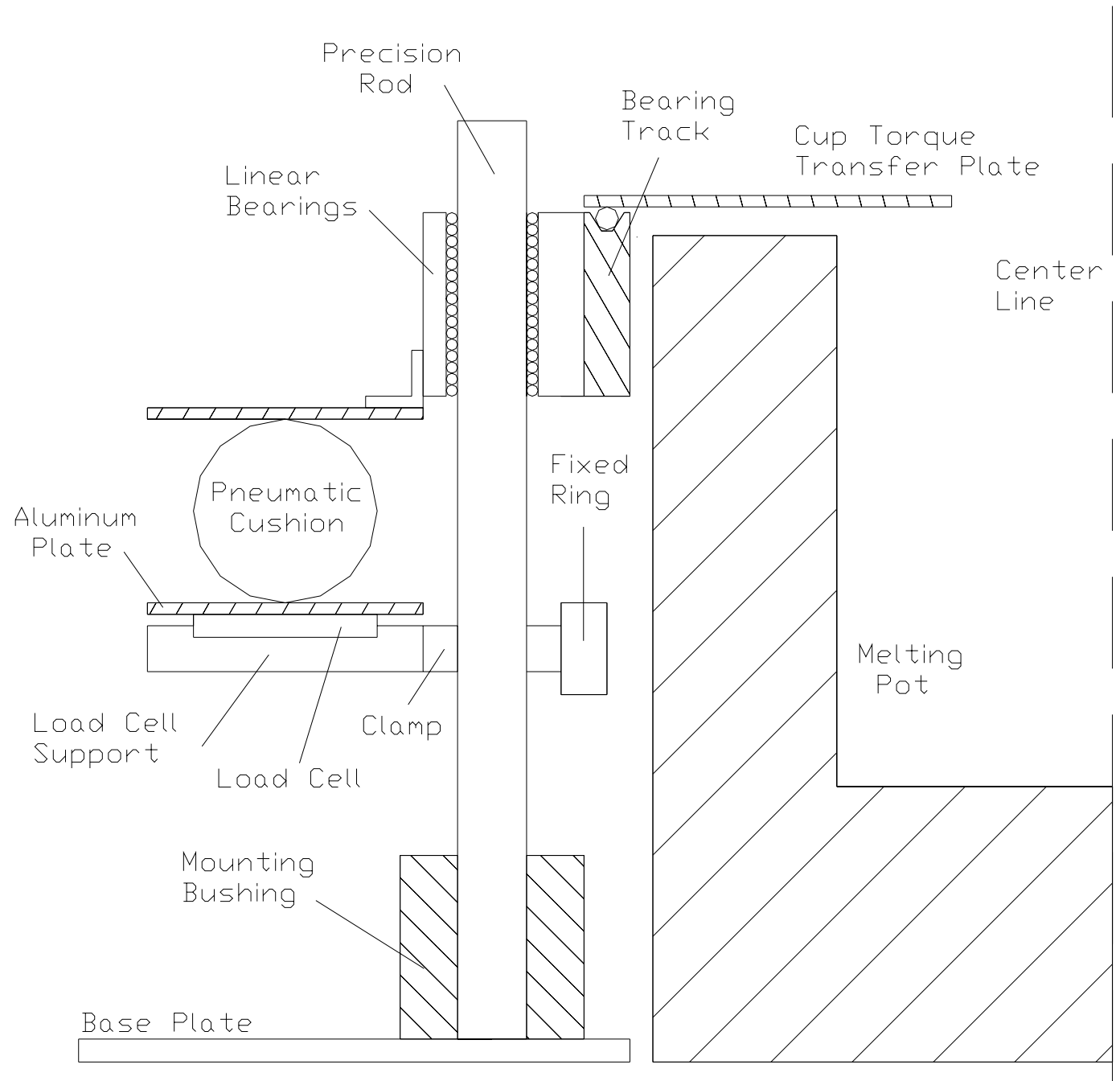

Figure 2.15: Cross Section of the Bearing Track Assembly 


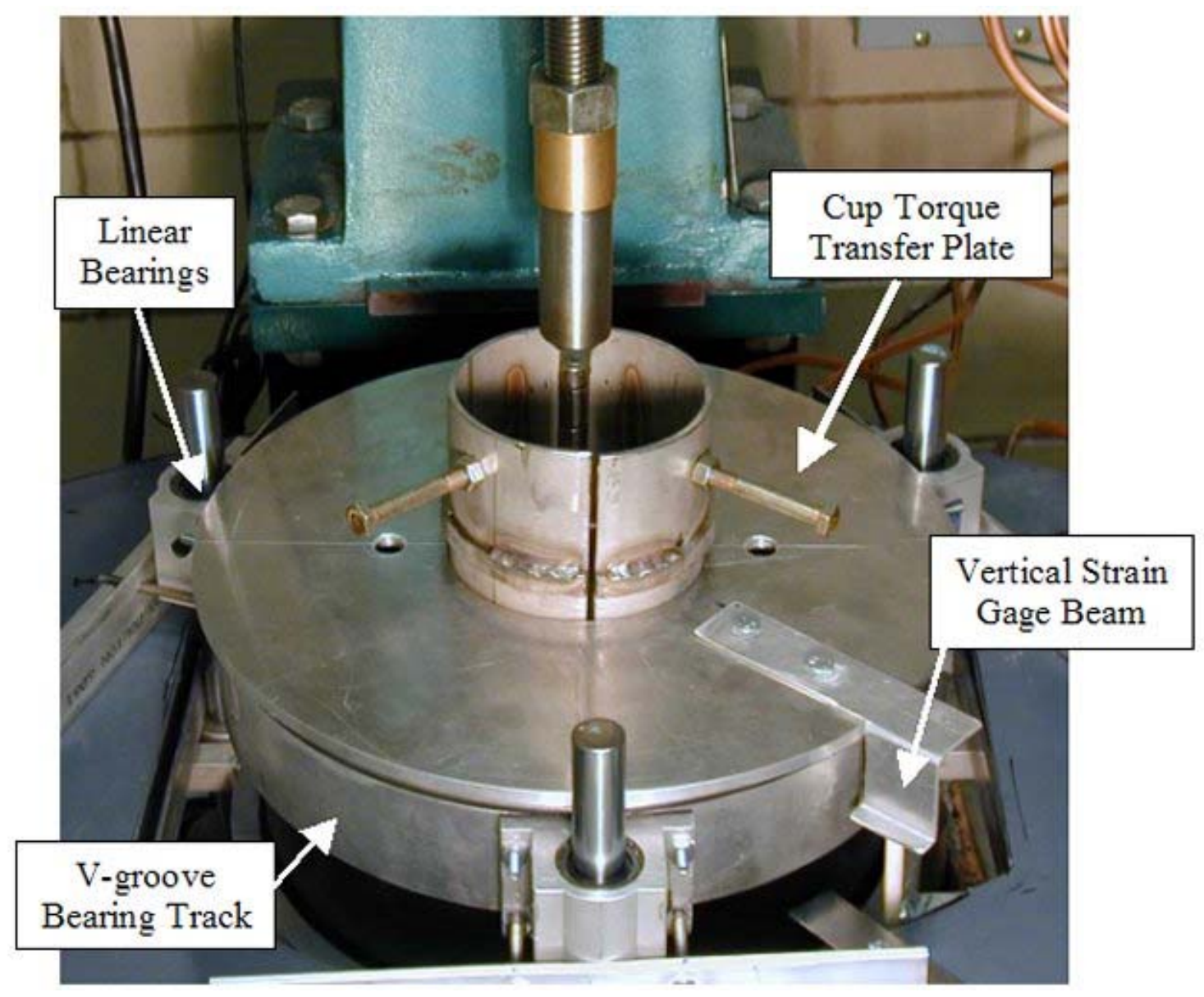

Figure 2.16: Picture of Bearing Track Assembly and Cup Torque Transfer Plate

The ball specimen was held in place by the use of a spindle. The bearing track assembly and mill bed were both cooled by use of water lines. Using the large contact area of a 5-inch aluminum disc to transfer the heat to a stationary water-cooled mating disc cooled the spindle. They made contact under spring pressure, see Figure 2.17. 


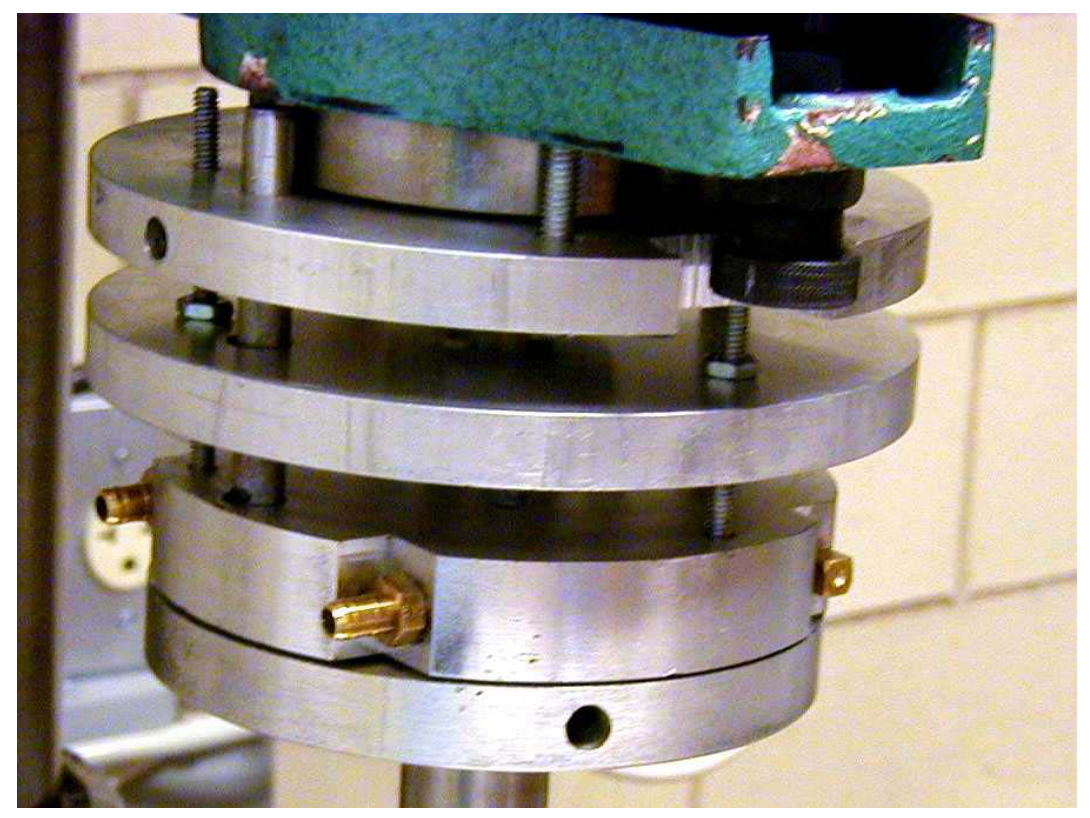

Figure 2.17: Water Cooled Spindle

The WVU wear tester is capable of testing a variety of zinc pot bearing materials. These materials include Stellite 6, MSA 2012, ORNL 4 (with WC-Laser Cladding), and 316 Stainless Steel (with WC-Laser Cladding). Stellite 6 and Stainless Steel are the most widely used bearing materials. Before testing, all materials were polished using three grades of diamond-lapping compound. An initial test matrix of the materials to be tested can be found in Table 2.10 . 
Table 2.10: Initial Material Test Matrix

\begin{tabular}{|l|l|l|l|l|l|}
\hline & $\begin{array}{l}\text { Seat: } \\
\text { 316SS }\end{array}$ & $\begin{array}{l}\text { Seat: } \\
\text { 316SS with } \\
\text { Laser Cladding }\end{array}$ & $\begin{array}{l}\text { Seat: } \\
\text { Stellite \#6 }\end{array}$ & $\begin{array}{l}\text { Seat: } \\
\text { ORNL-4 with } \\
\text { Laser Cladding }\end{array}$ & $\begin{array}{l}\text { Seat: } \\
\text { MSA } \\
\text { 2012 }\end{array}$ \\
\hline $\begin{array}{l}\text { Ball: } \\
\text { 316 SS }\end{array}$ & $\begin{array}{l}\text { Trial } \\
\text { Test }\end{array}$ & $\begin{array}{l}\text { Trial } \\
\text { Test }\end{array}$ & $\begin{array}{l}\text { Trial } \\
\text { Test }\end{array}$ & $\begin{array}{l}\text { Trial } \\
\text { Test }\end{array}$ & $\begin{array}{l}\text { Trial } \\
\text { Test }\end{array}$ \\
\hline $\begin{array}{l}\text { Ball: } \\
\text { Tungsten }\end{array}$ & $\begin{array}{l}\text { Trial } \\
\text { Test }\end{array}$ & $\begin{array}{l}\text { Trial } \\
\text { Test }\end{array}$ & $\begin{array}{l}\text { Trial } \\
\text { Test }\end{array}$ & $\begin{array}{l}\text { Trial } \\
\text { Test }\end{array}$ & $\begin{array}{l}\text { Trial } \\
\text { Test }\end{array}$ \\
\hline $\begin{array}{l}\text { Ball: } \\
\text { 316SS with } \\
\text { Laser Cladding }\end{array}$ & & & Test & & Test \\
\hline $\begin{array}{l}\text { Ball: } \\
\text { Stellite \#6 }\end{array}$ & & Test & Test & Test & Test \\
\hline $\begin{array}{l}\text { Ball: } \\
\text { ORNL-4 with } \\
\text { Laser Cladding }\end{array}$ & & & Test & & Test \\
\hline $\begin{array}{l}\text { Ball: } \\
\text { MSA 2012 }\end{array}$ & & Test & Test & Test & Test \\
\hline
\end{tabular}

Most materials in the test matrix can be machined, but some must be cast. One of the materials that must be cast is the ORNL 4 ball and seat specimens. This was done by the use of a cope and drag sand mold, design and constructed at WVU.

The seat specimen was held in place by the use of a stainless steel strut channel. This channel was then bolted to the inside of the specimen test cup. The stainless steel strut channel and specimen test cup with attached channel can be seen in Figures 2.18 and 2.19 respectively. 




Figure 2.18: Stainless Steel Strut Channel and Seat

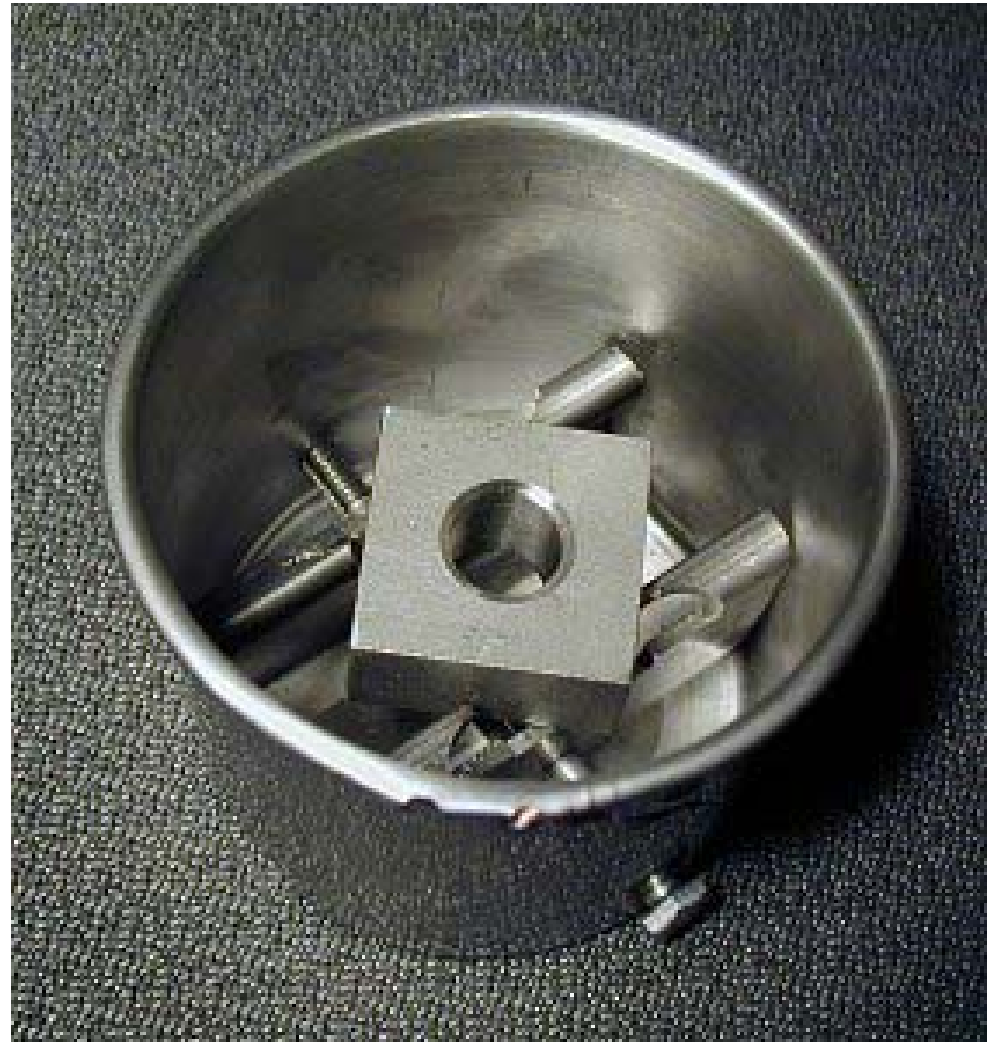

Figure 2.19: Stainless Steel Strut Channel and Seat Bolted into Specimen Cup 
Figure 2.20 shows the assembled WVU zinc pot bearing materials tester. This machine was used to test the friction coefficient and wear of zinc pot bearing materials.

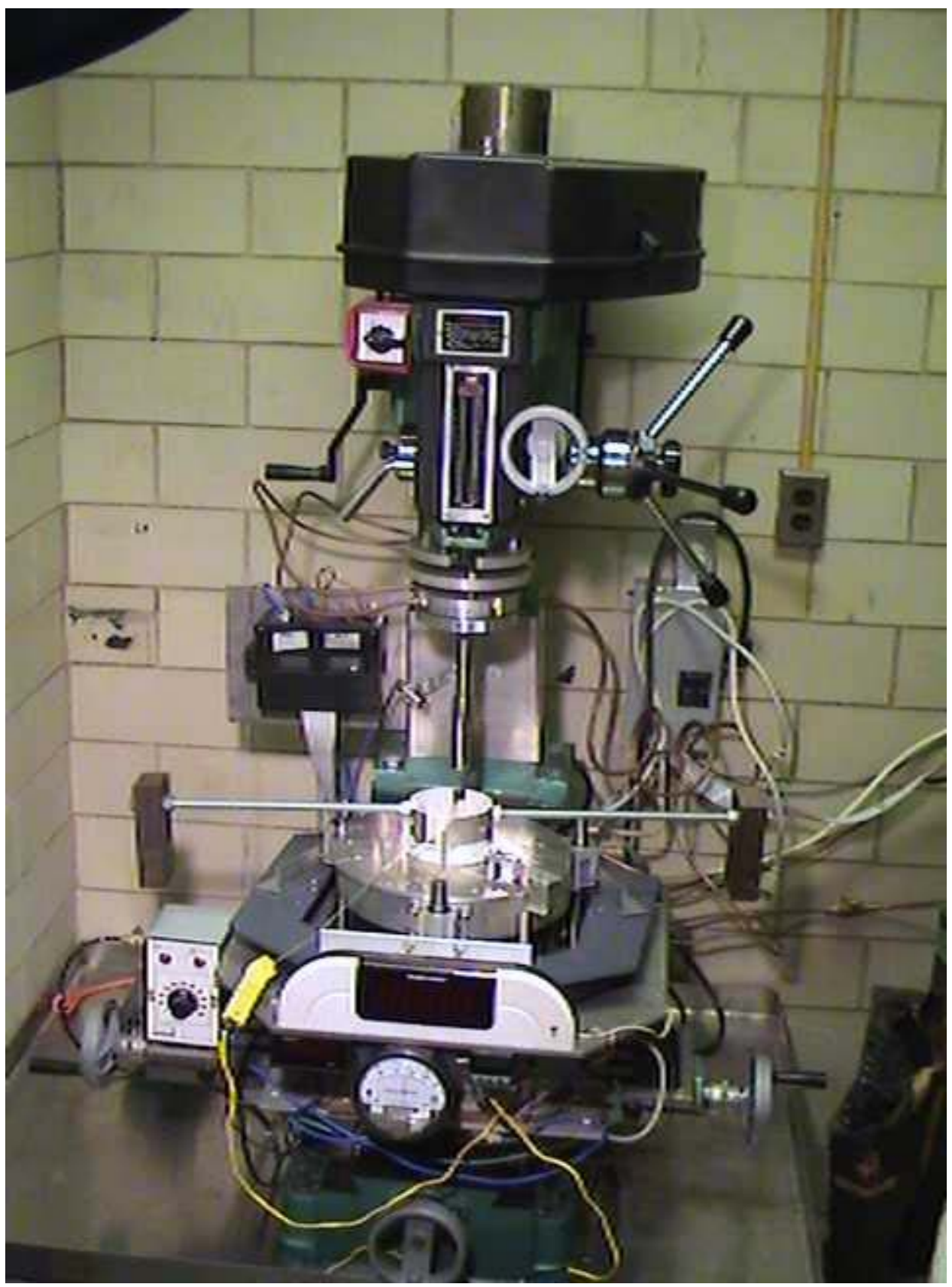

Figure 2.20: Assembled Zinc Pot Bearing Materials Tester 


\section{Chapter 3 - Material Wear Tester for Zinc-Pot Bearings}

\subsection{Improvement of Torque Strain Gage Beam}

During operation of the WVU zinc pot bearing materials tester it was observed that the output signal form the torque strain gage beam was insufficient to produce a reliable reading by the data acquisition computer program. The previous design used two $350 \Omega$ strain gages attached to each side of a $1 / 2$ inch wide aluminum beam. This design produced a conversion constant of $0.0898 \mathrm{lb}_{\mathrm{f}} / \mathrm{mV}$.

In order to improve the output signal a new torque strain gage beam was designed. Four $120 \Omega$ strain gages were attached to a 6061-T6 aluminum beam. The four strain gages were wired in a bridge configuration with a $25 \Omega$ potentiometer for zero balancing. With the new design a conversion constant of $0.0103 \mathrm{lb}_{\mathrm{f}} / \mathrm{mV}$ was obtained. A schematic of the torque strain gage beam can be seen in Figure 3.1. 




Figure 3.1: Improved Torque Strain Gage Beam 


\section{2 - Design of New Test Spindle}

After performing tests using the spindle design described in Ryan Ware's thesis, the spindle began to wobble about its axis. The problem occurred at the junction of the Stainless Steel thin walled tubing and the 1-inch tubing. At this junction the fit between the two tubes was not secure. This indicated the need for a new test spindle.

The new spindle had to meet certain criteria, the first of which is that it had to be hollow so that a push rod could be inserted to remove the ball after a test was complete. The second criterion was that the hollow spindle allows a press fit attachment for the ball test specimen. With these criterion defined a new spindle was designed. The new design used a 3/4-inch O.D. piece of stainless steel tube with a 1/2-inch inside diameter for the main spindle. At the spindle end was a 3-inch long by 1-inch O.D. piece of stainless steel tubing attached. It is needed hold the 3.3-inch long 0.97-inch I.D. tubing, in to which the ball specimen is press fitted. The 1-inch O.D. tubing was pinned to the 3/4-inch tubing so that rotation was prevented during testing. A $1 / 2$-inch thick by 5-inch radius aluminum disk was attached to the upper portion of the spindle for contact against a spring-loaded water-cooled disc of the same size. A diagram of the new spindle is shown in Figure 3.2. 


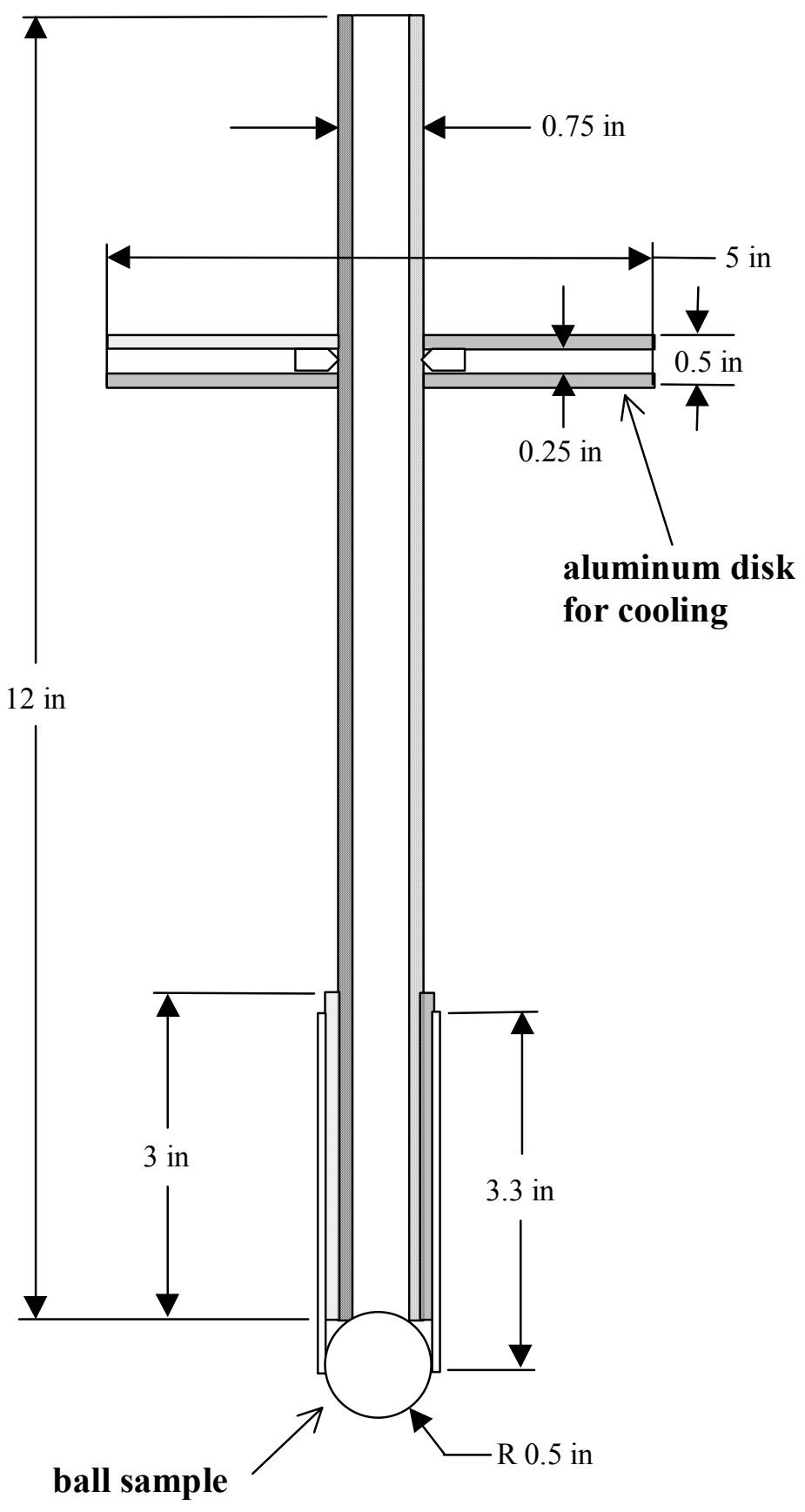

Figure 3.2: Rotating Spindle Design 


\section{3 - Zinc Pot Failure}

During heating of the melting pot, its liner failed. After approximately 200 hours of operation the corrosive properties of the zinc produced a hole in the lining of the melting pot. The hole allowed the molten zinc to flow into the cavity between the pot lining and the outer shell where the heating elements are contained. This leak destroyed the pot.

A new melting pot was ordered with the same specifications as the old pot, with the addition of an electroplated chromed steel liner. The electroplated pot liner was painted with Boron Nitride Lubricoat to help further reduce the corrosion of the liner.

To minimize future melting pot problems, tin is now used in the pot in the place of zinc. The tin was placed in the melting pot to heat the zinc in the test cup to the desired test temperature. Tin has significantly lower corrosive properties than zinc and therefore will not attack the pot liner as rapidly. A tight fit prevents this coming in contact with the zinc inside the stainless steel cup holding the test specimen. 


\section{Chapter 4 - On-Line Data Acquisition Computer Program}

\subsection{Data Acquisition Computer Program}

An Analog Devices RTI-800 Multifunction Input/Output Board was used to collect the four analog data signals produced by the zinc pot bearing tester during operation. A Quick Basic ${ }^{\circledR}$ computer program was written to run the RTI-800 board and store the collected signals in a database. The data collected was in the from of $\mathrm{mV}$ signals for the load, torque, RPM and temperature. With the use of an A/D converter the RTI-800 Board transforms the $\mathrm{mV}$ analog signals to 12-bit binary signals. This data was collected for 15 minutes with a sample being taken every 1 second. A 1 second interval was chosen since the RTI- 800 Board is not capable of sample rates of less than 1 second. With the collected data saved to a database it was then possible to transform the data using Microsoft Excel $^{\circledR}$ to determine the friction coefficient of the bearing materials tested. See Appendix A for a copy of the Quick Basic ${ }^{\circledR}$ computer program. 


\section{Chapter 5 - Friction Coefficient and Wear Data Analysis Procedure}

\subsection{Friction Coefficient Analysis Procedure}

The four voltage data signals collected from the data acquisition computer program were saved to a database, which could be opened and saved as a Microsoft Excel $^{\circledR}$ workbook. With the data in useable format it was then possible to calculate the sliding friction coefficient. The first step in this calculation procedure is to remove the gains from the voltage signal. This is done by dividing the collected voltage signal by its respective gain. Next, the voltage signal may be transformed to the proper units using the calibration constants found in Table 5.1. These constants were determined by calibrating the various strain gages, load cells, RPM meter and thermometer found on the WVU zinc pot bearing materials tester. A description of the calibration method and data collected can be found in Appendix B.

Table 5.1: Calibration Constants for Materials Tester

\begin{tabular}{|c|c|}
\hline Instrument & Calibration Constant \\
\hline Torque Strain Gage Beam & $0.031 \mathrm{lb}_{\mathrm{f}} / \mathrm{mV}$ \\
\hline Load Cells & $0.4587 \mathrm{lb}_{\mathrm{f}} / \mathrm{mV}$ \\
\hline Thermocouples & $1^{\circ} \mathrm{F} / \mathrm{mV}$ \\
\hline RPM Sensor & $0.2189 \mathrm{RPM} / \mathrm{mV}$ \\
\hline
\end{tabular}

In order to remove any outlying data points from the data signal, an over-lap save method was employed. This method uses a moving average of the data to arrive at a new data point by averaging four data points together for a new point and saving the last three points used in the average for the next averaged point. This averaging procedure was used for all of the 900 data points collected during the friction coefficient test.

Because the ball rests on the seat at a $45^{\circ}$ contact angle, the actual surface contact force is increased to $\mathrm{F}_{\text {contact }}=2\left(\mathrm{~F}_{\text {load }} * \sin 45^{\circ}\right)=\mathrm{F}_{\text {load }} * \sqrt{ } 2$. The friction torque at a moment 
$\operatorname{arm} r_{c}=1 / 2$-inch $* \sin \left(45^{\circ}\right)=1 / 4 * \sqrt{ } 2=0.3535$-inches. The strain gage moment arm $\ell_{\text {gage }}$ $=6.75$-inch. With the data converted and averaged, the friction coefficient can now be calculated using the following formula [13]:

$$
\mu_{F}=\frac{F_{\text {gage }} *\left(\ell_{\text {gage }}=6.75 \text { inch }\right)}{F_{\text {contact }} *\left(r_{c}=1 / 4 * \sqrt{2} \text { inch }\right)}=\frac{13.5 * F_{\text {gage }}}{F_{\text {load }}}
$$

The Friction Power dissipation rate, for the ball/seat system is the product of ball/seat load, contact velocity and friction coefficient. Using the following formula gives wear rate as a function of the friction power dissipation rate, which can be determined for each test.

$$
\text { Friction Power }=V_{c} * F_{\text {load }} * \sqrt{2} * \mu_{f}
$$

From experiments performed at constant contact pressure, wear is a linear function of time and the square root of contact velocity. But at constant velocity it is proportional to

contact pressure squared, $\mathrm{P}_{\mathrm{c}}{ }^{2}$. Therefore wear rate is proportional to power loading equals $\mathrm{P}_{\mathrm{c}}^{2}(\mathrm{psi}) * \sqrt{ } \mathrm{V}_{\mathrm{c}}(\mathrm{inch} / \mathrm{sec})=\mathrm{lb}_{\mathrm{f}}{ }^{2} /\left(\mathrm{inch}^{3 / 2} * \sec ^{1 / 2}\right)$

\subsection{Wear Analysis Procedure}

The wear of the various test materials was determined by measuring the seat material lost over a length of time at a prescribed set of test conditions. In order to determine the loss of material, the average initial horizontal seat width $\mathrm{W}_{\mathrm{i}}$ was measured before starting the wear test, using an optical magnifier with a measurement scale inside. The $6 \mathrm{X}$ optical magnifier was capable of measuring to the nearest $0.1-\mathrm{mm}$. The seat 
width measurements were taken in four locations, North, South, East and West, as seen in Figure 5.1. These four measurements were then averaged to arrive at an average seat width, $\mathrm{W}_{\mathrm{i}}$.

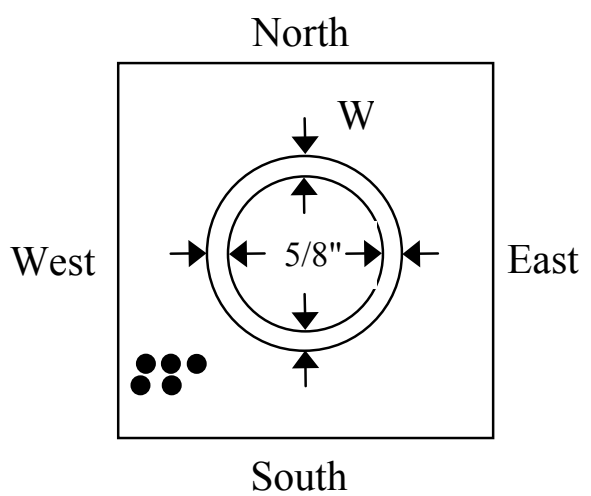

Figure 5.1: Measurement Locations on Seat Specimen

To obtain the amount of material lost from the sloped seat, a wear depth must be determined. This is done by dividing the average gain in seat width, $\left(\mathrm{W}_{\mathrm{f}}-\mathrm{W}_{\mathrm{I}}\right)=\Delta \mathrm{W}$, by the square root of 2 as seen in the following formula.

$$
\text { WearDepth }=\frac{\Delta W}{\sqrt{2}}
$$

This depth accounts for the loss of material on the $45^{\circ}$ sloped seat, which can be seen in Figure 5.2. 


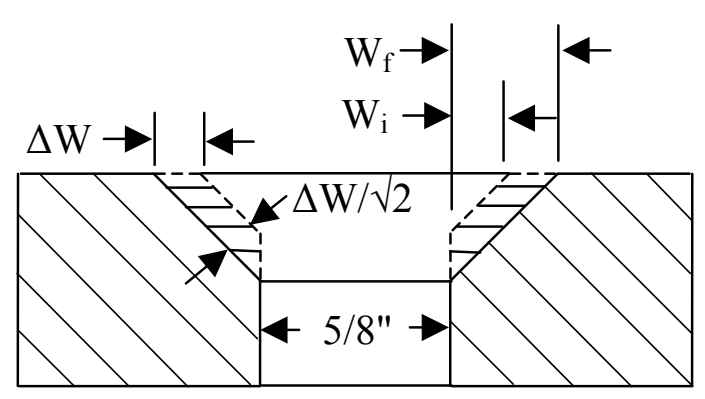

Figure 5.2: Wear Location of Seat Specimen

Next, the actual seat area was calculated using the seat width, $\mathrm{W}_{\mathrm{i}}$, by the following

$$
A_{\text {seat }}=\frac{\pi}{4}\left(\left(5 / 8^{\prime \prime}+2 * W_{i}\right)^{2}-\left(5 / 8^{\prime \prime}\right)^{2}\right) * \sqrt{2}
$$

formula.

Multiplying this initial actual seat area by the wear depth provides the seat material lost.

The average wear rate was calculated with the use of the wear depth and test duration.

$$
\text { Wear Rate }=\left(\frac{\Delta W}{\sqrt{2}}\right) / t
$$




\section{Chapter 6 - Wear and Friction Coefficient Results}

\subsection{Material Test Conditions}

The materials tested for this project were selected by attendees of the Spring 2002 Conference meeting held at Oak Ridge National Laboratory. Most of these materials have been tested at WVU using contact pressures and velocities corresponding to average steel mill galvanizing line operating conditions. Figure 6.1 shows the relationship between contact velocity, $\mathrm{V}_{\mathrm{c}}$, and RPM of the WVU zinc pot bearing tester. Figure 6.2 shows the relationship between ball/seat pressure and spindle load. Both of these Figures are based on an average $45^{\circ}$ contact angle of a 1-inch diameter ball, with a mean seat contact diameter of 0.707 -inches. Because of the 5/8-inch diameter hole in the center, the projected seat area equals $0.171-\mathrm{inch}^{2}$. In both of these Figures are indicated the corresponding operating conditions at Weirton Steel galvanizing lines 3, 4, and 5. Most of tests were run with a contact pressure, $\mathrm{P}_{\mathrm{c}}$, and a contact velocity, $\mathrm{V}_{\mathrm{c}}$, corresponding to those used on line 3 and 4. 


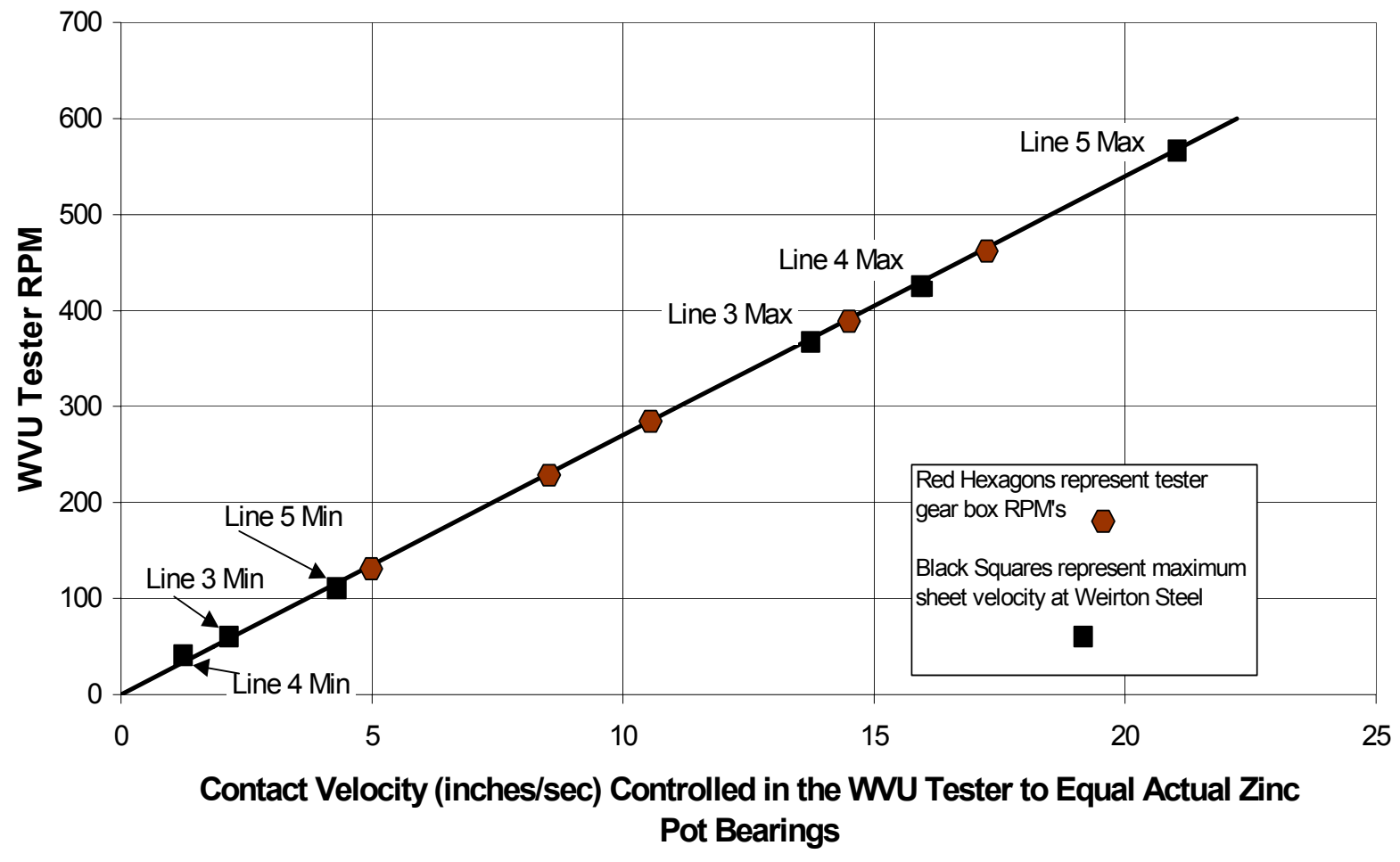

Figure 6.1: Contact Velocity as a Function of Bearing Tester RPM with Symbols Indicating Typical Contact Velocities Employed at Weirton Steel 




Figure 6.2: Contact Pressure as a Function of Spindle Load with Symbols Indicating Typical Contact Pressures Used at Weirton Steel

\subsection{Test Samples Sources}

Several industries provided test samples at no cost to WVU. Their contributions to this project are highly appreciated. Mike Brennan of Praxair Surface Technologies provided the Stellite \#6 weld overlay and the laser-clad tungsten carbide ball and seat specimens. The MSA 2012 ball and seat specimens were provided by Mark Bright of Metaullics Molten Metal Systems. In addition, Metaullics provided 1-inch hemispherical ball samples of MSA 2020 for testing. Ed Dean of Vesuvius McDanel provided ceramic seats for testing and Vinod Sikka provided both Stellite \#6 and ORNL-4. 


\subsection{Wear Tests in Water}

To determine the effects of contact velocity and initial contact pressure on material wear, a series of water tests were conducted. The first of these was performed with a Stainless Steel ball specimen on a Stainless Steel seat specimen to determine the wear rate as a function of time at various velocities. Shown in Figure 6.3 are the results from this test. The results showed that wear rate is linear with time.

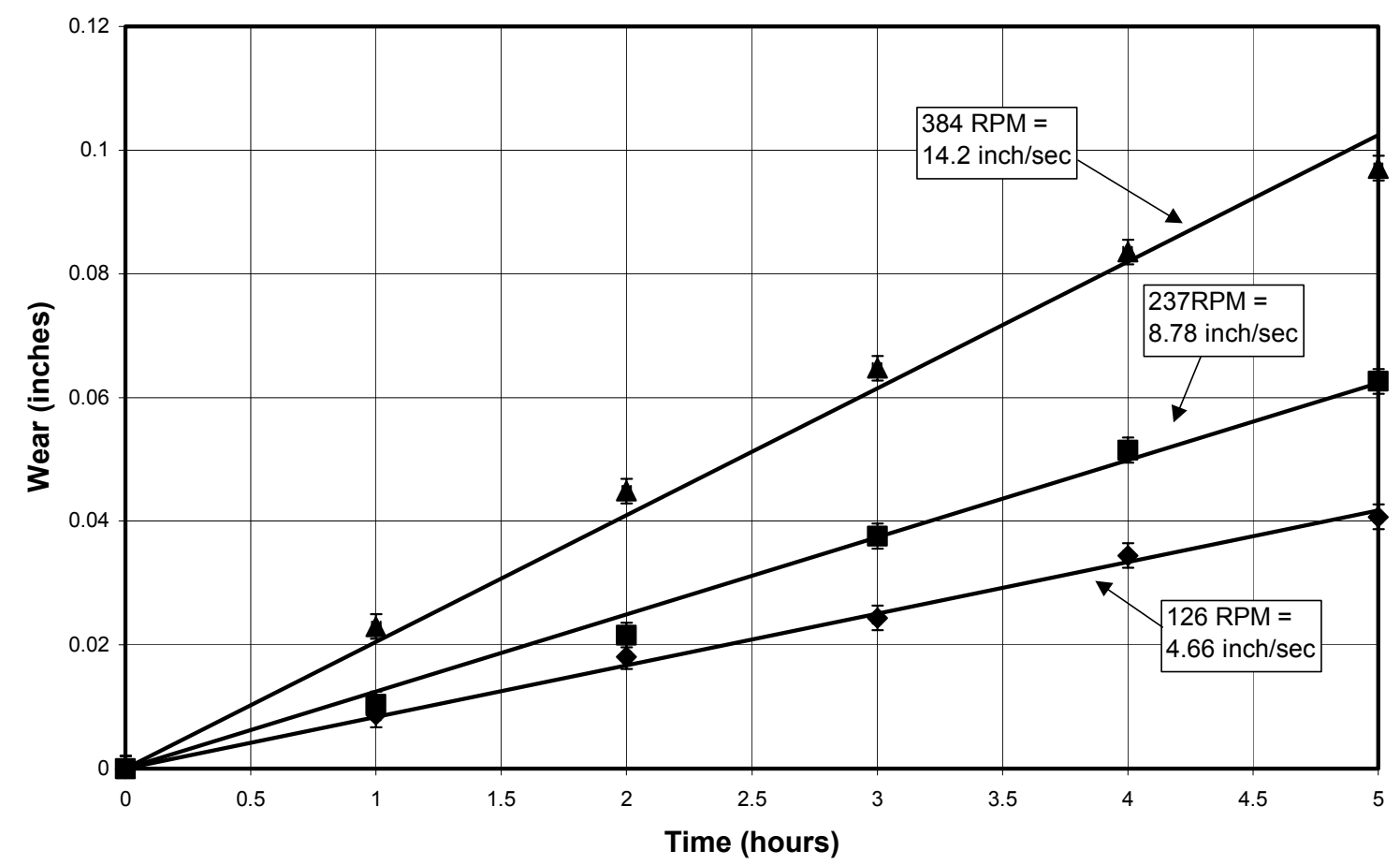

Figure 6.3: Wear of Stainless Steel on Stainless Steel as a Function of Time at an Initial Contact Pressure of 100 psi and Various Contact Velocities in Water

The wear rate as a function of initial contact pressure was a determined using a Stainless Steel ball specimen on a Stainless Steel seat specimen. These tests were performed at various RPM's. Figure 6.4 shows that the wear rate is a quadratic of contact pressure. In order to account for this non-linearity a curve fit was conducted, which 
determined that the wear rate is equal to $\mathrm{C}^{*} \mathrm{P}_{\mathrm{c}}{ }^{2} * \sqrt{ } \mathrm{V}_{\mathrm{c}}$. Where $\mathrm{C}$ is a proportionality constant. This relation is shown in Figure 6.5.

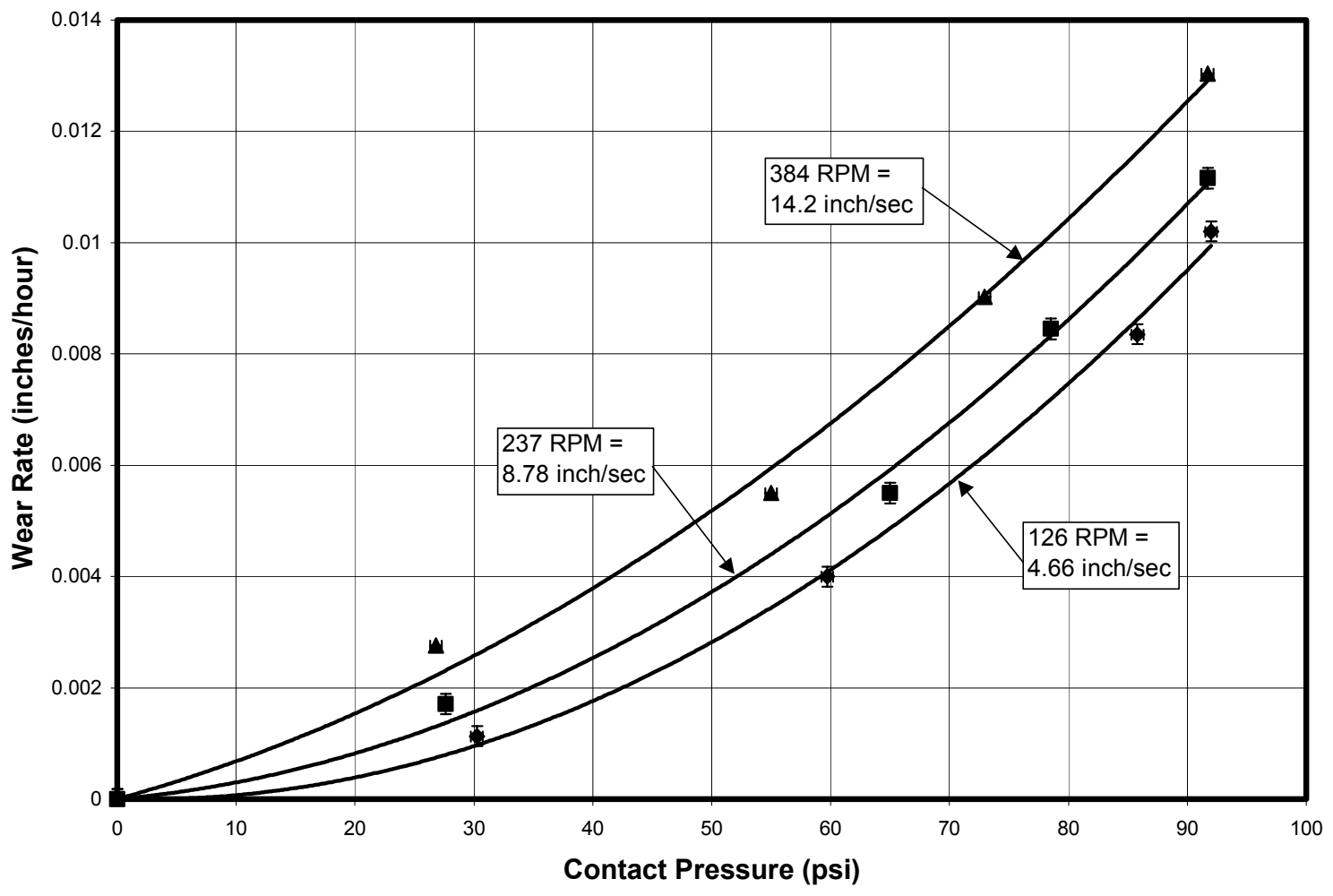

Figure 6.4: Wear as a Function of Contact Pressure for Stainless Steel on Stainless Steel at Various Contact Velocities in Water 


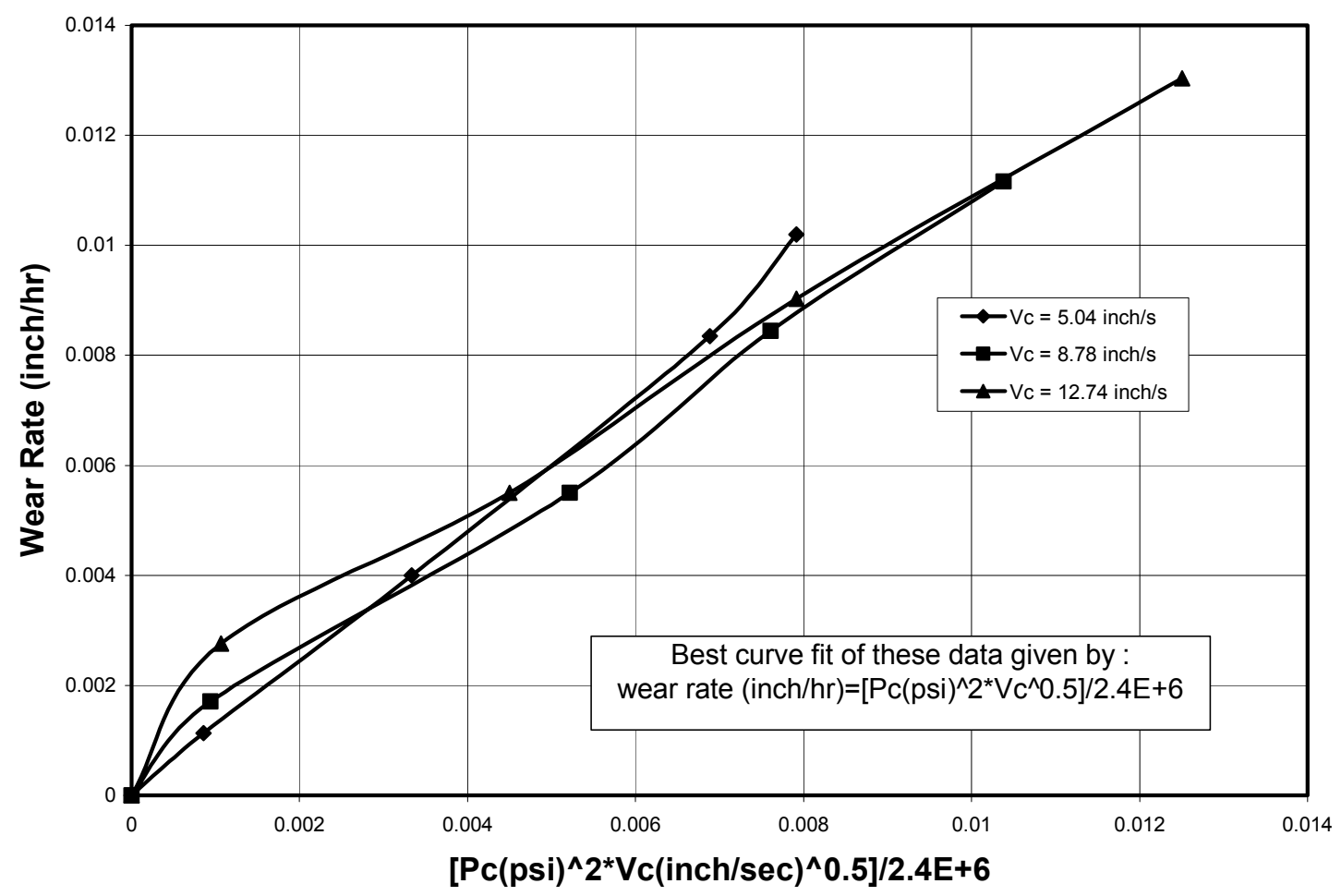

Figure 6.5: Wear Rate of Stainless Steel on Stainless Steel in Water and Curve Fitted as a Function of Contact Pressure and Velocity

A Stellite \#6 ball specimen on a Stellite \#6 seat specimen were also tested in water to determine if wear rate as a function of time remained linear. As shown in Figure 6.6 , the wear rate remained linear with time for Stellite \#6. 


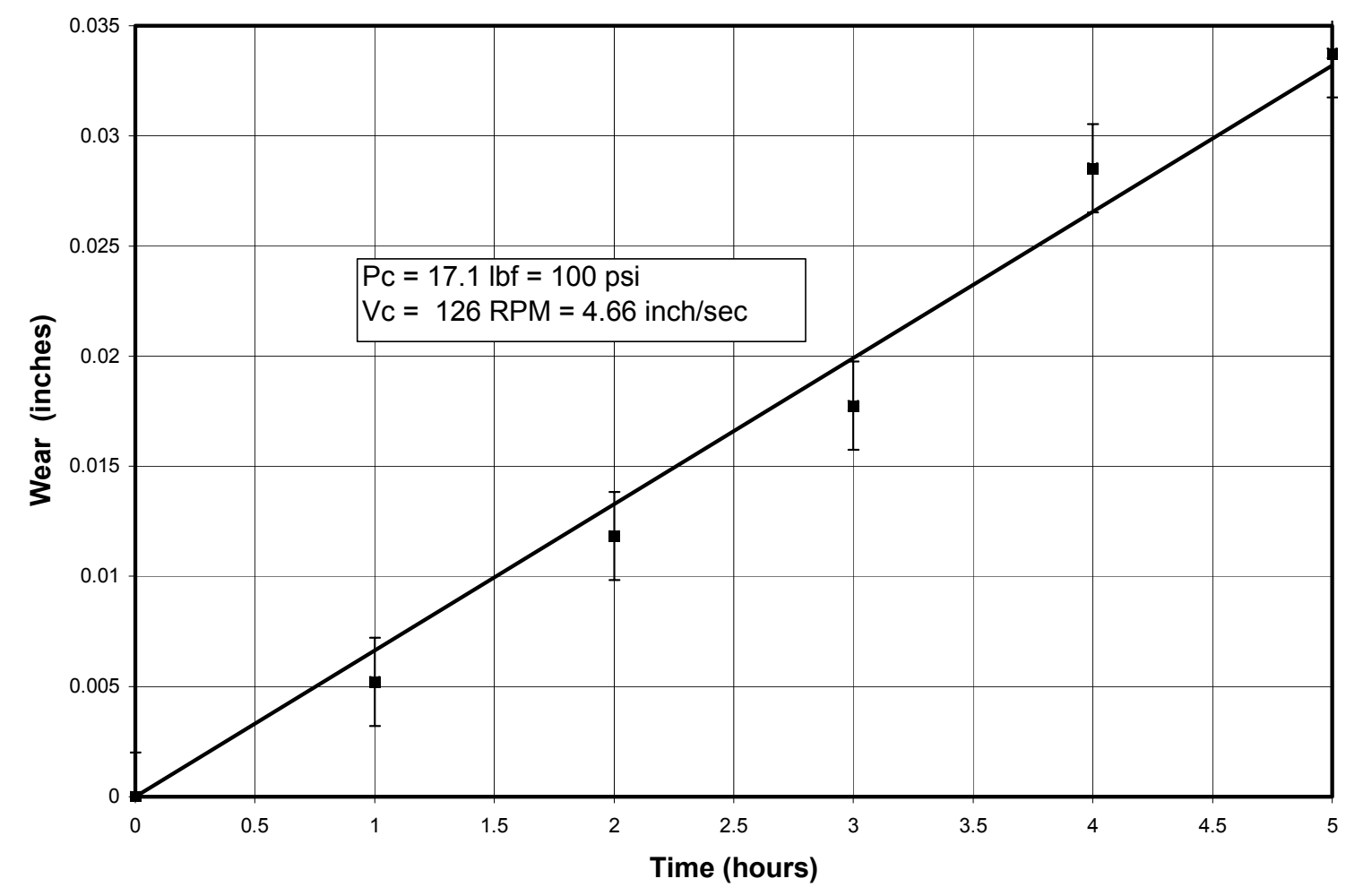

Figure 6.6: Wear of Stellite \#6 on Stellite \#6 as a Function of Time in Water at a Contact Pressure of 100 psi and a Contact Velocity of 4.56 inches/sec

A test was also performed to determine the effects of contact pressure on the wear rate of a Stellite \#6 ball specimen on a Stellite \#6 seat specimen. The wear rate as a function of contact pressure is non-linear, as shown in Figure 6.7. A curve fit was performed for this material that determined that the wear rate was equal to $\mathrm{C}^{*} \mathrm{P}_{\mathrm{c}}{ }^{2} * \sqrt{ } \mathrm{V}_{\mathrm{c}}$, as shown in Figure 6.8. 




Figure 6.7: Wear as a Function of Contact Pressure for a Stellite \#6 Ball on a Stellite \#6 Seat at a Contact Velocity of 4.66 inches/sec in Water 


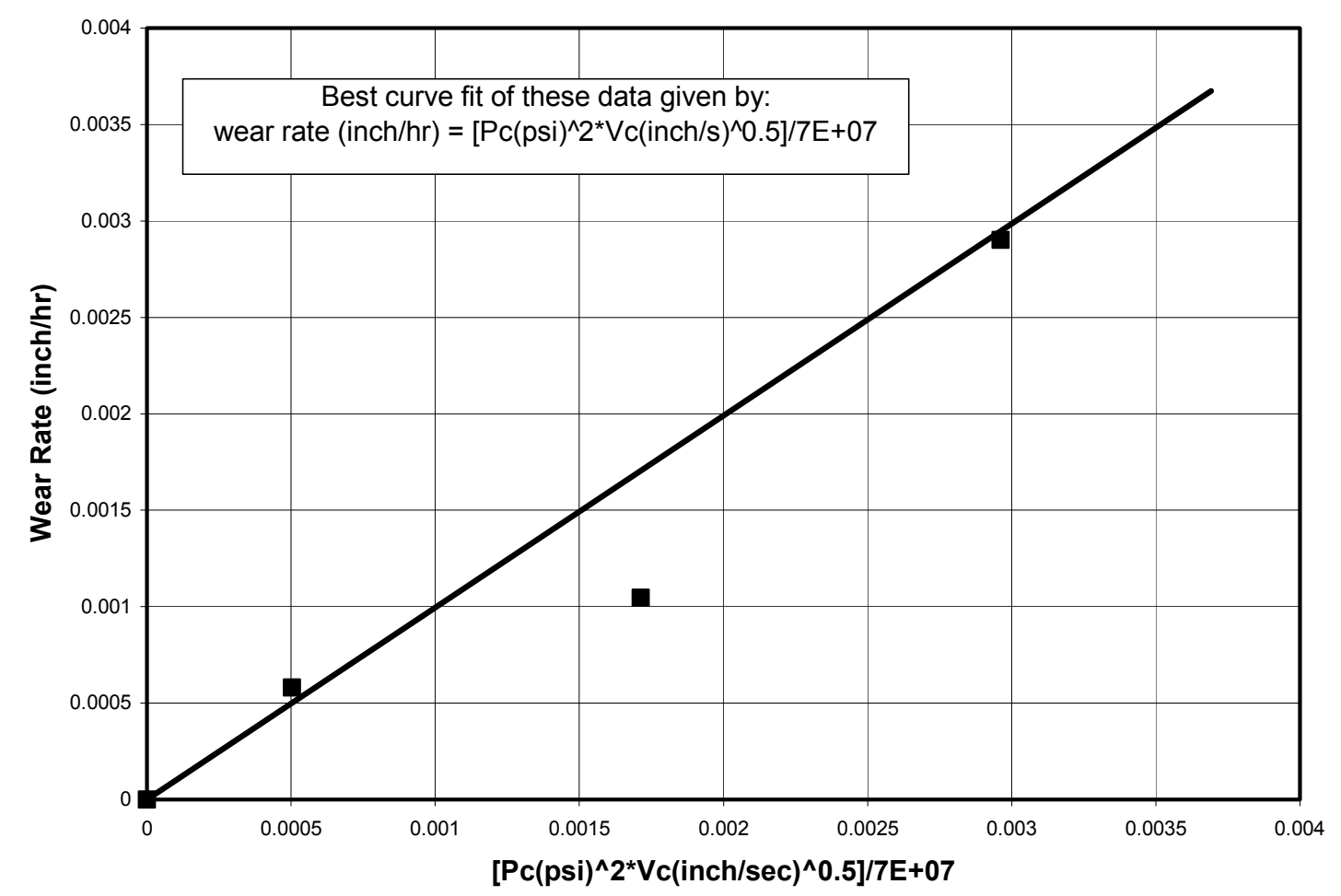

Figure 6.8: Wear Rate of Stellite \#6 on Stellite \#6 in Water and Curve Fitted as a Function of Contact Pressure and Velocity

The above cold water tests for combinations of stainless steel on stainless steel and Stellite \#6 on Stellite \#6 showed that the wear rate is linear with time and non-linear with respect to contact pressure.

\subsection{Hot Zinc Tests}

Hot zinc tests were performed in molten zinc to determine the sliding friction coefficient and wear rate of various material combinations. The seat widths were measured before and after each wear test and the friction coefficient was determined during the wear test. Each sample was oxidized before each test by placing it in close 
proximity to the molten tin bath at approximately $860^{\circ} \mathrm{F}$. Figures 6.9 through 6.15 show the results of the friction coefficient tests performed on various material combinations.

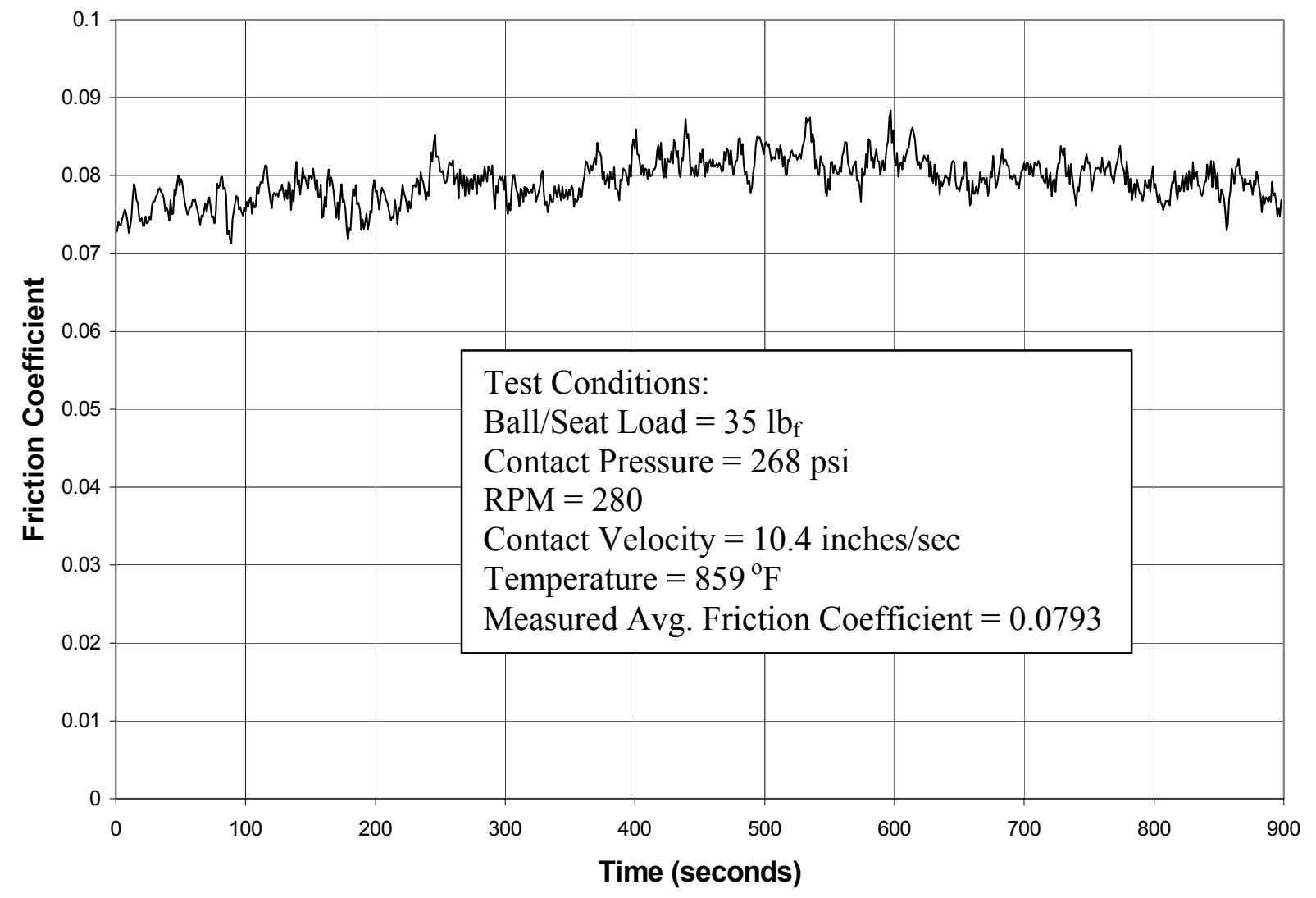

Figure 6.9: Friction Coefficient of a MSA 2012 Ball on a Stellite \#6 Seat as a Function of Time 




Figure 6.10: Friction Coefficient of a MSA 2012 Ball on a Laser-Clad Tungsten Carbide Seat as a Function of Time 


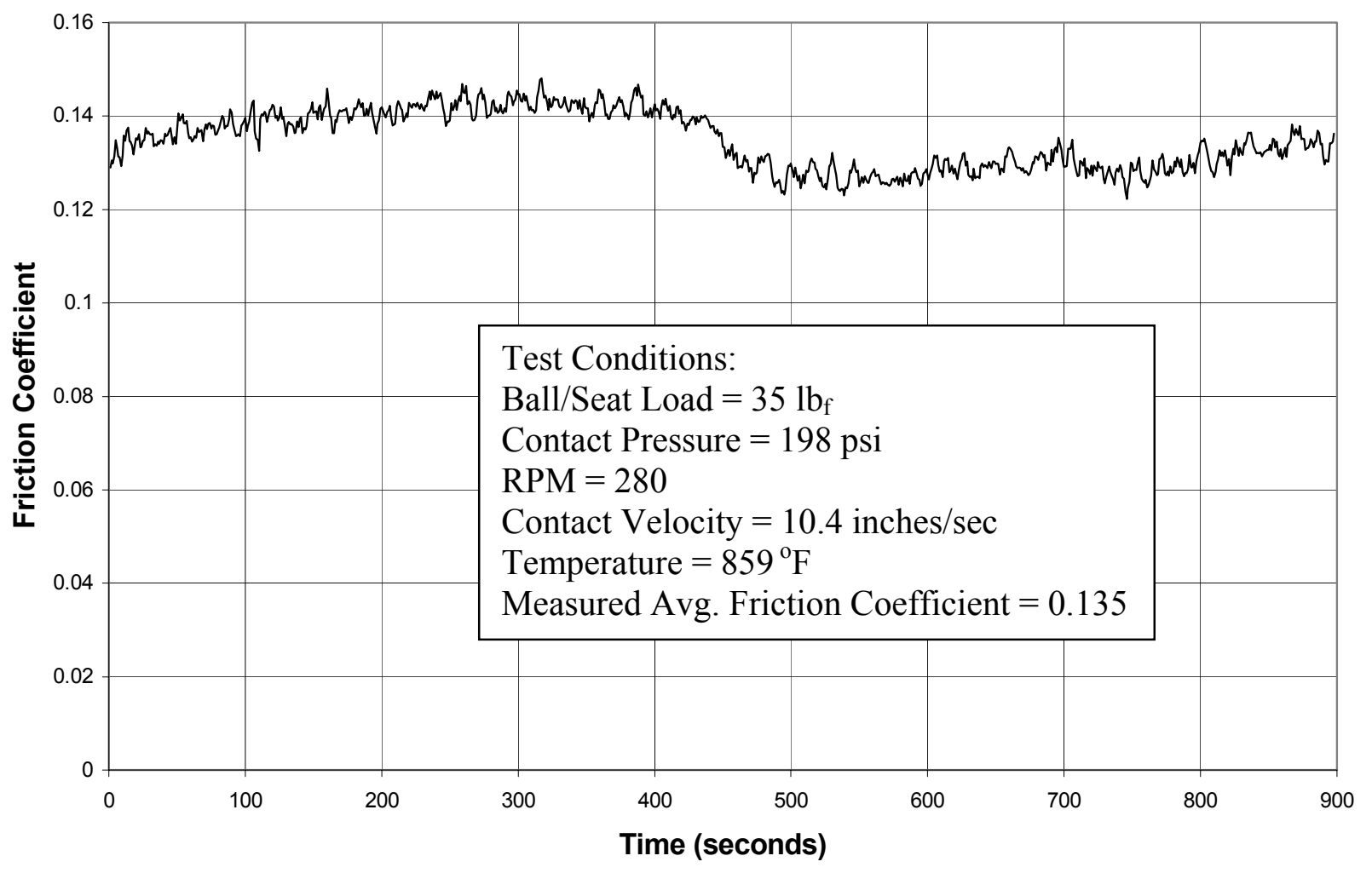

Figure 6.11: Friction Coefficient of a MSA 2020 Ball on a Laser-Clad Tungsten Carbide Seat as a Function of Time 


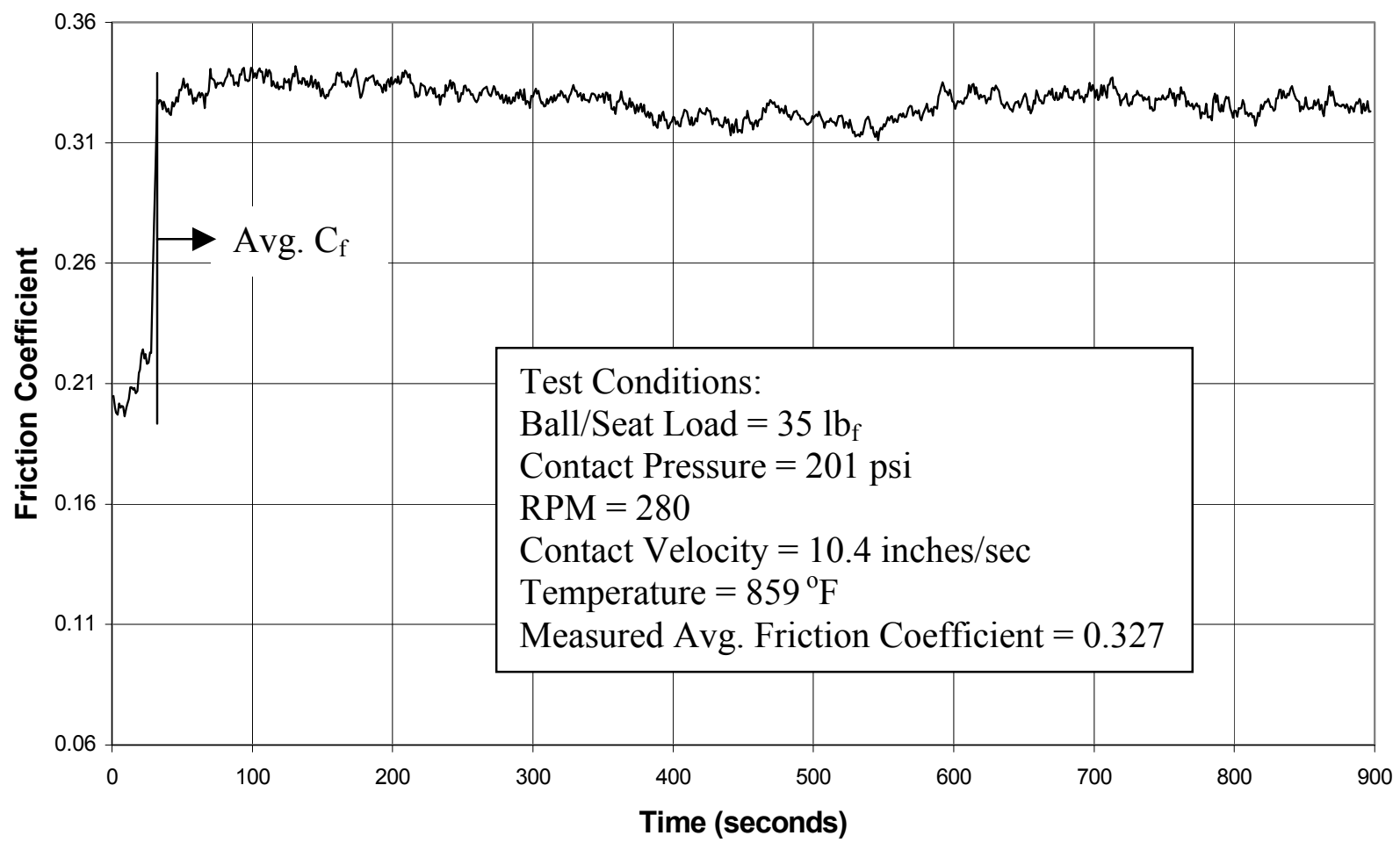

Figure 6.12: Friction Coefficient of a MSA 2020 Ball on a MSA 2012 Seat as a Function of Time 


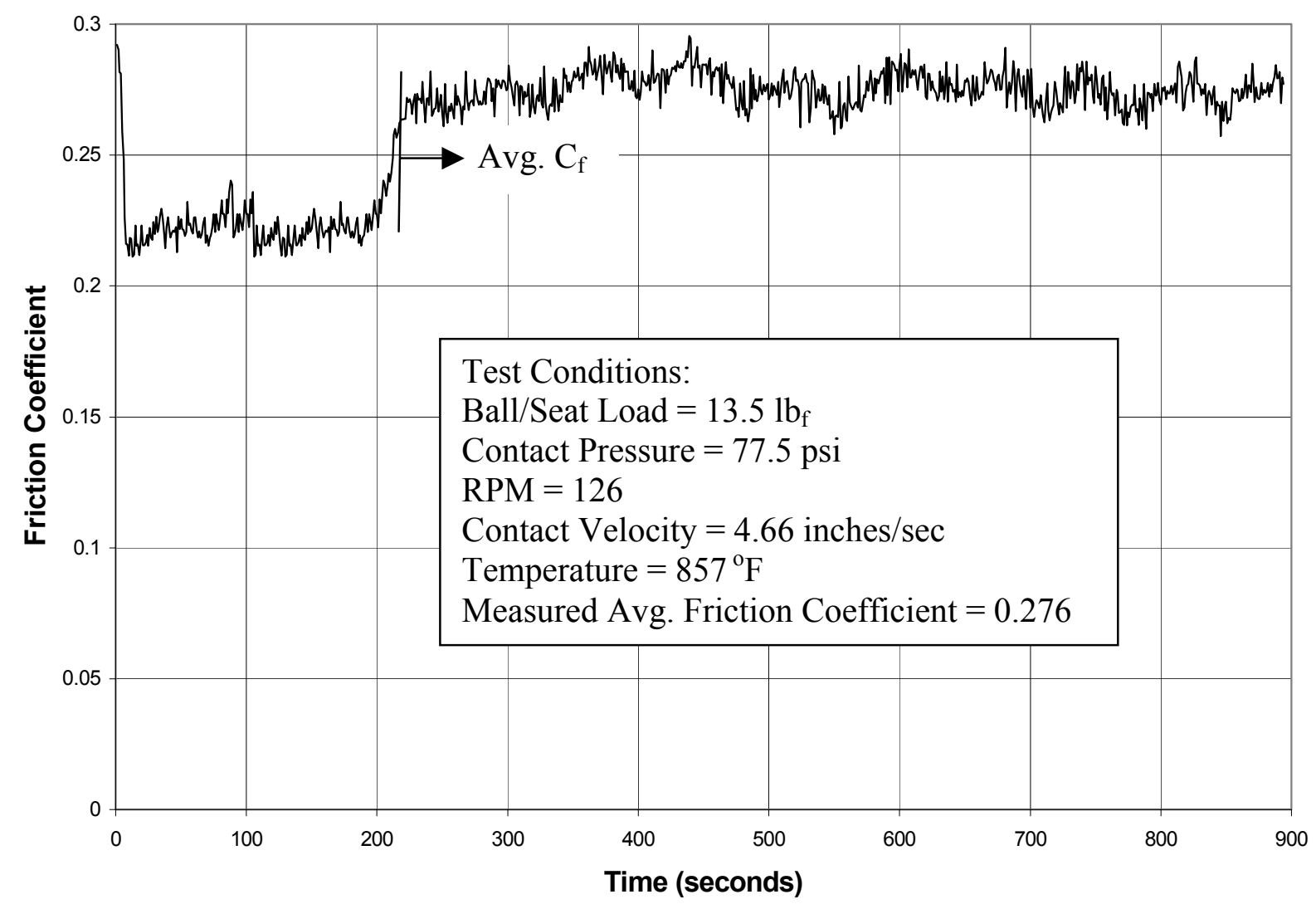

Figure 6.13: Friction Coefficient of a MSA 2012 Ball on a MSA 2012 Seat as a Function of Time 


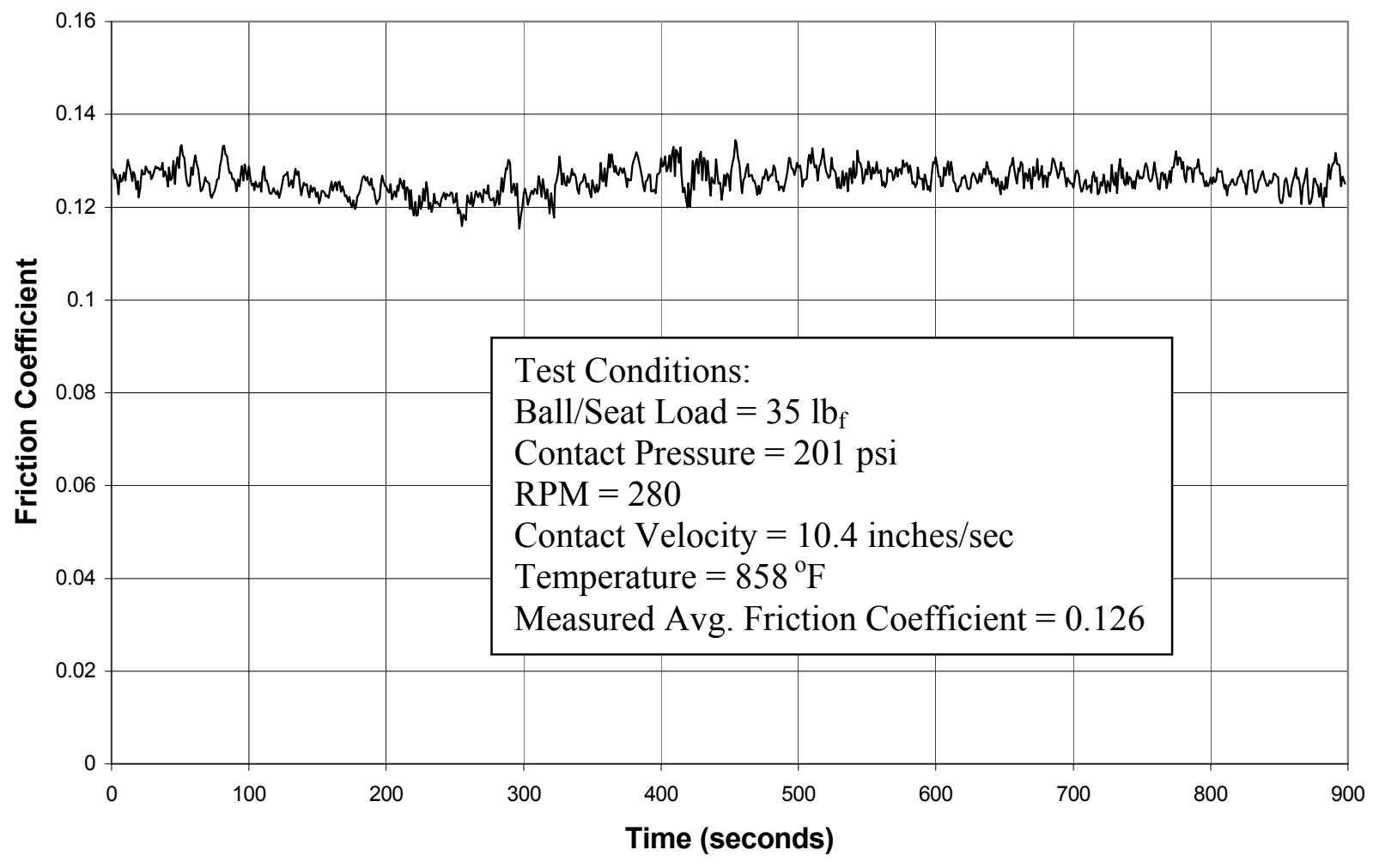

Figure 6.14: Friction Coefficient of a Stellite \#6 Ball on a MSA 2012 Seat as a Function of Time 




Figure 6.15: Friction Coefficient of a Laser-Clad Tungsten Carbide Ball on a
MSA 2012 Seat as a Function of Time

The wear rates of various material combinations were determined by measuring the increase in seat width at four locations, North, South, East and West. With this information the wear rate and initial and final horizontal seat areas were determined. Table 6.1 shows the wear rate of various material combinations along with the test specifications. 
Table 6.1: Wear Rate and Friction Power of Various Material Combinations

\begin{tabular}{|c|c|}
\hline Stationary Ball Seat Material with $5 / 8$ " hole & Stellite $\# 6$ Weld Overlay \\
\hline Spindle Ball End Material & Laser Clad - Tungsten Carbide \\
\hline Test Date & July 7, 2002 \\
\hline Contact Velocity, $\mathrm{V}_{\mathrm{c}}=\mathrm{RPM} / 27=126 / 27$ & $4.66 \mathrm{in} / \mathrm{sec}$ \\
\hline Initial Contact Pressure, $\mathrm{P}_{\mathrm{c}}=\mathrm{Load} / \mathrm{A}_{\mathrm{hi}}=10.51 \mathrm{~b}_{\mathrm{f}} / \mathrm{A}_{\mathrm{hi}}$ & $60.3 \mathrm{psi}$ \\
\hline Test Duration, $\mathrm{t}$ & $20 \mathrm{hours}$ \\
\hline Average Cup Test Temperature & $870{ }^{\circ} \mathrm{F}$ \\
\hline Horizontal Seat Width, $\mathrm{W}_{\mathrm{hi}}$ and $\mathrm{W}_{\mathrm{hf}}$ & $0.0787 \mathrm{in.}-0.119 \mathrm{in}$. \\
\hline Initial Horizontal Seat Area, $\mathrm{A}_{\mathrm{hi}}=\pi\left(\mathrm{r}_{\mathrm{i}}{ }^{2}-5 / 16^{2}\right)$ & $0.174 \mathrm{in}^{2}$ \\
\hline Final Horizontal Seat Area, $\mathrm{A}_{\mathrm{hf}}=\pi\left(\mathrm{r}_{\mathrm{f}}{ }^{2}-5 / 16^{2}\right)$ & $0.278 \mathrm{in}$ \\
\hline Average Wear Rate, $\left(\mathrm{r}_{\mathrm{f}}-\mathrm{r}_{\mathrm{i}}\right) /\left(\mathrm{t}^{*} 2^{1 / 2}\right)$ & $0.00143 \mathrm{in} / \mathrm{hr}$ \\
\hline Friction Coefficient, $\mu_{\mathrm{f}}$ & 0.358 \\
\hline Friction Power $=\mathrm{V}_{\mathrm{c}}{ }^{*} \mathrm{~F}_{\theta}=\mathrm{V}_{\mathrm{c}}{ }^{*}$ Load $^{*} \mu_{\mathrm{f}}$ & $17.5\left(\mathrm{lb}_{\mathrm{f}}{ }^{*} \mathrm{in}\right) / \mathrm{sec}$ \\
\hline
\end{tabular}

*subscript $\mathrm{i}$ indicates initial at start of test, subscript $\mathrm{f}$ indicates final at end of test

\begin{tabular}{|c|c|}
\hline Stationary Ball Seat Material with $5 / 8$ " hole & Stellite \#6 Weld Overlay \\
\hline Spindle Ball End Material & MSA 2012 \\
\hline Test Date & November 12,2002 \\
\hline Contact Velocity, $\mathrm{V}_{\mathrm{c}}=\mathrm{RPM} / 27=280 / 27$ & $10.4 \mathrm{in} / \mathrm{sec}$ \\
\hline Initial Contact Pressure, $P_{c}=$ Load $/ A_{h i}=351 b_{f} / A_{h i}$ & $268 \mathrm{psi}$ \\
\hline Test Duration, $\mathrm{t}$ & 5.25 hours \\
\hline Average Cup Test Temperature & $859^{\circ} \mathrm{F}$ \\
\hline Horizontal Seat Width, $\mathrm{W}_{\mathrm{hi}}$ and $\mathrm{W}_{\mathrm{hf}}$ & 0.0605 in. -0.0778 in. \\
\hline Initial Horizontal Seat Area, $A_{h i}=\pi\left(r_{i}^{2}-5 / 16^{2}\right)$ & $0.130 \mathrm{in}^{2}$ \\
\hline Final Horizontal Seat Area, $A_{h f}=\pi\left(r_{f}^{2}-5 / 16^{2}\right)$ & 0.172 in $^{2}$ \\
\hline Average Wear Rate, $\left(\mathrm{r}_{\mathrm{f}}-\mathrm{r}_{\mathrm{i}}\right) /\left(\mathrm{t} * 2^{1 / 2}\right)$ & $0.00232 \mathrm{in} / \mathrm{hr}$ \\
\hline Friction Coefficient, $\mu_{\mathrm{f}}$ & 0.0793 \\
\hline Friction Power $=V_{c}{ }^{*} F_{\theta}=V_{c}^{*}$ Load $^{*} \mu_{\mathrm{f}}$ & $28.9\left(\mathrm{lb}_{\mathrm{f}}^{*}\right.$ in $) / \mathrm{sec}$ \\
\hline
\end{tabular}




\begin{tabular}{|c|c|}
\hline Stationary Ball Seat Material with $5 / 8^{\prime \prime}$ hole & Laser Clad - Tungsten Carbide \\
\hline Spindle Ball End Material & MSA 2012 \\
\hline Test Date & November 12, 2002 \\
\hline Contact Velocity, $\mathrm{V}_{\mathrm{c}}=\mathrm{RPM} / 27=280 / 27$ & $10.4 \mathrm{in} / \mathrm{sec}$ \\
\hline Initial Contact Pressure, $\mathrm{P}_{\mathrm{c}}=$ Load $/ \mathrm{A}_{\mathrm{hi}}=351 \mathrm{~b}_{\mathrm{f}} / \mathrm{A}_{\mathrm{hi}}$ & $204 \mathrm{psi}$ \\
\hline Test Duration, $\mathrm{t}$ & $5.25 \mathrm{hours}$ \\
\hline Average Cup Test Temperature & $8588^{\circ} \mathrm{F}$ \\
\hline Horizontal Seat Width, $\mathrm{W}_{\mathrm{hi}}$ and $\mathrm{W}_{\mathrm{hf}}$ & $0.0778 \mathrm{in.}-0.0851 \mathrm{in}$. \\
\hline Initial Horizontal Seat Area, $\mathrm{A}_{\mathrm{hi}}=\pi\left(\mathrm{r}_{\mathrm{i}}{ }^{2}-5 / 16^{2}\right)$ & $0.172 \mathrm{in}^{2}$ \\
\hline Final Horizontal Seat Area, $\mathrm{A}_{\mathrm{hf}}=\pi\left(\mathrm{r}_{\mathrm{f}}{ }^{2}-5 / 16^{2}\right)$ & $0.190 \mathrm{in}$ \\
\hline Average Wear Rate, $\left(\mathrm{r}_{\mathrm{f}}-\mathrm{r}_{\mathrm{i}}\right) /\left(\mathrm{t}^{*} 2^{1 / 2}\right)$ & $0.000994 \mathrm{in} / \mathrm{hr}$ \\
\hline Friction Coefficient, $\mu_{\mathrm{f}}$ & 0.134 \\
\hline Friction Power $=\mathrm{V}_{\mathrm{c}}{ }^{*} \mathrm{~F}_{\theta}=\mathrm{V}_{\mathrm{c}}{ }^{*}$ Load $^{*} \mu_{\mathrm{f}}$ & $48.8\left(\mathrm{lb}_{\mathrm{f}}{ }^{*} \mathrm{in}\right) / \mathrm{sec}$ \\
\hline
\end{tabular}

\begin{tabular}{|c|c|}
\hline Stationary Ball Seat Material with 5/8" hole & Laser Clad - Tungsten Carbide \\
\hline Spindle Ball End Material & MSA 2020 \\
\hline Test Date & November 11,2002 \\
\hline Contact Velocity, $\mathrm{V}_{\mathrm{c}}=\mathrm{RPM} / 27=280 / 27$ & $10.4 \mathrm{in} / \mathrm{sec}$ \\
\hline Initial Contact Pressure, $\mathrm{P}_{\mathrm{c}}=\mathrm{Load} / \mathrm{A}_{\mathrm{hi}}=351 \mathrm{~b}_{\mathrm{f}} / \mathrm{A}_{\mathrm{hi}}$ & $198 \mathrm{psi}$ \\
\hline Test Duration, $\mathrm{t}$ & $6.1 \mathrm{hours}$ \\
\hline Average Cup Test Temperature & $856^{\circ} \mathrm{F}$ \\
\hline Horizontal Seat Width, $\mathrm{W}_{\mathrm{hi}}$ and $\mathrm{W}_{\mathrm{hf}}$ & $0.0797 \mathrm{in} .-0.0915 \mathrm{in}$. \\
\hline Initial Horizontal Seat Area, $\mathrm{A}_{\mathrm{hi}}=\pi\left(\mathrm{r}_{\mathrm{i}}{ }^{2}-5 / 16^{2}\right)$ & $0.176 \mathrm{in}^{2}$ \\
\hline Final Horizontal Seat Area, $\mathrm{A}_{\mathrm{hf}}=\pi\left(\mathrm{r}_{\mathrm{f}}{ }^{2}-5 / 16^{2}\right)$ & $0.206 \mathrm{in}$ \\
\hline Average Wear Rate, $\left(\mathrm{r}_{\mathrm{f}}-\mathrm{r}_{\mathrm{i}}\right) /\left(\mathrm{t}^{*} 2^{2 / 2}\right)$ & $0.00137 \mathrm{in} / \mathrm{hr}$ \\
\hline Friction Coefficient, $\mu_{\mathrm{f}}$ & 0.135 \\
\hline Friction Power $=\mathrm{V}_{\mathrm{c}}{ }^{*} \mathrm{~F}_{\theta}=\mathrm{V}_{\mathrm{c}}{ }^{*} \mathrm{Load}^{*} \mu_{\mathrm{f}}$ & $49.1\left(\mathrm{~b}_{\mathrm{f}}{ }^{*} \mathrm{in}\right) / \mathrm{sec}$ \\
\hline
\end{tabular}

\begin{tabular}{|c|c|}
\hline Stationary Ball Seat Material with 5/8" hole & MSA 2012 \\
\hline Spindle Ball End Material & MSA 2012 \\
\hline Test Date & September 11, 2002 \\
\hline Contact Velocity, $\mathrm{V}_{\mathrm{c}}=\mathrm{RPM} / 27=126 / 27$ & $4.66 \mathrm{in} / \mathrm{sec}$ \\
\hline Initial Contact Pressure, $\mathrm{P}_{\mathrm{c}}=\mathrm{Load} / \mathrm{A}_{\mathrm{hi}}=13.51 \mathrm{~b}_{\mathrm{f}} / \mathrm{A}_{\mathrm{hi}}$ & $77.5 \mathrm{psi}$ \\
\hline Test Duration, $\mathrm{t}$ & 17 hours \\
\hline Average Cup Test Temperature & $870^{\circ} \mathrm{F}$ \\
\hline Horizontal Seat Width, $\mathrm{W}_{\mathrm{hi}}$ and $\mathrm{W}_{\mathrm{hf}}$ & $0.0787 \mathrm{in} .-0.0866 \mathrm{in}$. \\
\hline Initial Horizontal Seat Area, $\mathrm{A}_{\mathrm{hi}}=\pi\left(\mathrm{r}_{\mathrm{i}}{ }^{2}-5 / 16^{2}\right)$ & $0.174 \mathrm{in}^{2}$ \\
\hline Final Horizontal Seat Area, $\mathrm{A}_{\mathrm{hf}}=\pi\left(\mathrm{r}_{\mathrm{f}}{ }^{2}-5 / 16^{2}\right)$ & $0.194 \mathrm{in}{ }^{2}$ \\
\hline Average Wear Rate, $\left(\mathrm{r}_{\mathrm{f}}-\mathrm{r}_{\mathrm{i}}\right) /\left(\mathrm{t}^{*} 2^{1 / 2}\right)$ & $0.000328 \mathrm{in} / \mathrm{hr}$ \\
\hline Friction Coefficient, $\mu_{\mathrm{f}}$ & 0.276 \\
\hline Friction Power $=\mathrm{V}_{\mathrm{c}}{ }^{*} \mathrm{~F}_{\theta}=\mathrm{V}_{\mathrm{c}}{ }^{*} \mathrm{Load}^{*} \mu_{\mathrm{f}}$ & $17.4\left(\mathrm{~b}_{\mathrm{f}}{ }^{*} \mathrm{in}\right) / \mathrm{sec}$ \\
\hline
\end{tabular}




\begin{tabular}{|c|c|}
\hline Stationary Ball Seat Material with $5 / 8$ " hole & MSA 2012 \\
\hline Spindle Ball End Material & MSA 2020 \\
\hline Test Date & November 1, 2002 \\
\hline Contact Velocity, $\mathrm{V}_{\mathrm{c}}=\mathrm{RPM} / 27=280 / 27$ & $10.4 \mathrm{in} / \mathrm{sec}$ \\
\hline Initial Contact Pressure, $\mathrm{P}_{\mathrm{c}}=$ Load $/ \mathrm{A}_{\mathrm{hi}}=351 \mathrm{~b}_{\mathrm{f}} / \mathrm{A}_{\mathrm{hi}}$ & $201 \mathrm{psi}$ \\
\hline Test Duration, $\mathrm{t}$ & $5.25 \mathrm{hours}$ \\
\hline Average Cup Test Temperature & $859^{\circ} \mathrm{F}$ \\
\hline Horizontal Seat Width, $\mathrm{W}_{\mathrm{hi}}$ and $\mathrm{W}_{\mathrm{hf}}$ & $0.0787 \mathrm{in.}-0.0906 \mathrm{in}$. \\
\hline Initial Horizontal Seat Area, $\mathrm{A}_{\mathrm{hi}}=\pi\left(\mathrm{r}_{\mathrm{i}}{ }^{2}-5 / 16^{2}\right)$ & $0.174 \mathrm{in}^{2}$ \\
\hline Final Horizontal Seat Area, $\mathrm{A}_{\mathrm{hf}}=\pi\left(\mathrm{r}_{\mathrm{f}}{ }^{2}-5 / 16^{2}\right)$ & $0.204 \mathrm{in}$ \\
\hline Average Wear Rate, $\left(\mathrm{r}_{\mathrm{f}}-\mathrm{r}_{\mathrm{i}}\right) /\left(\mathrm{t}^{*} 2^{1 / 2}\right)$ & $0.00159 \mathrm{in} / \mathrm{hr}$ \\
\hline Friction Coefficient, $\mu_{\mathrm{f}}$ & 0.327 \\
\hline Friction Power $=\mathrm{V}_{\mathrm{c}}{ }^{*} \mathrm{~F}_{\theta}=\mathrm{V}_{\mathrm{c}}{ }^{*}$ Load $^{*} \mu_{\mathrm{f}}$ & $119.0\left(\mathrm{~b}_{\mathrm{f}}{ }^{*} \mathrm{in}\right) / \mathrm{sec}$ \\
\hline
\end{tabular}

\begin{tabular}{|c|c|}
\hline Stationary Ball Seat Material with 5/8" hole & MSA 2012 \\
\hline Spindle Ball End Material & Stellite $\# 6$ Weld Overlay \\
\hline Test Date & November 11,2002 \\
\hline Contact Velocity, $\mathrm{V}_{\mathrm{c}}=\mathrm{RPM} / 27=280 / 27$ & $10.4 \mathrm{in} / \mathrm{sec}$ \\
\hline Initial Contact Pressure, $\mathrm{P}_{\mathrm{c}}=\mathrm{Load} / \mathrm{A}_{\mathrm{hi}}=351 \mathrm{~b}_{\mathrm{f}} / \mathrm{A}_{\mathrm{hi}}$ & $201 \mathrm{psi}$ \\
\hline Test Duration, $\mathrm{t}$ & $5.25 \mathrm{hours}$ \\
\hline Average Cup Test Temperature & $858^{\circ} \mathrm{F}$ \\
\hline Horizontal Seat Width, $\mathrm{W}_{\mathrm{hi}}$ and $\mathrm{W}_{\mathrm{hf}}$ & $0.0787 \mathrm{in.}-0.0866 \mathrm{in}$. \\
\hline Initial Horizontal Seat Area, $\mathrm{A}_{\mathrm{hi}}=\pi\left(\mathrm{r}_{\mathrm{i}}{ }^{2}-5 / 16^{2}\right)$ & $0.174 \mathrm{in}^{2}$ \\
\hline Final Horizontal Seat Area, $\mathrm{A}_{\mathrm{hf}}=\pi\left(\mathrm{r}_{\mathrm{f}}{ }^{2}-5 / 16^{2}\right)$ & $0.194 \mathrm{in}$ \\
\hline Average Wear Rate, $\left(\mathrm{r}_{\mathrm{f}}-\mathrm{r}_{\mathrm{i}}\right) /\left(\mathrm{t}^{*} 2^{2 / 2}\right)$ & $0.00106 \mathrm{in} / \mathrm{hr}$ \\
\hline Friction Coefficient, $\mu_{\mathrm{f}}$ & 0.126 \\
\hline Friction Power $=\mathrm{V}_{\mathrm{c}}{ }^{*} \mathrm{~F}_{\theta}=\mathrm{V}_{\mathrm{c}}{ }^{*} \mathrm{Load}^{*} \mu_{\mathrm{f}}$ & $45.9\left(\mathrm{~b}_{\mathrm{f}}{ }^{*} \mathrm{in}\right) / \mathrm{sec}$ \\
\hline
\end{tabular}

\begin{tabular}{|c|c|}
\hline Stationary Ball Seat Material with 5/8" hole & MSA 2012 \\
\hline Spindle Ball End Material & Laser Clad - Tungsten Carbide \\
\hline Test Date & November 2,2002 \\
\hline Contact Velocity, $\mathrm{V}_{\mathrm{c}}=\mathrm{RPM} / 27=280 / 27$ & $10.4 \mathrm{in} / \mathrm{sec}$ \\
\hline Initial Contact Pressure, $\mathrm{P}_{\mathrm{c}}=\mathrm{Load} / \mathrm{A}_{\mathrm{hi}}=351 \mathrm{~b}_{\mathrm{f}} / \mathrm{A}_{\mathrm{hi}}$ & $201 \mathrm{psi}$ \\
\hline Test Duration, $\mathrm{t}$ & $5.25 \mathrm{hours}$ \\
\hline Average Cup Test Temperature & $857^{\circ} \mathrm{F}$ \\
\hline Horizontal Seat Width, $\mathrm{W}_{\mathrm{hi}}$ and $\mathrm{W}_{\mathrm{hf}}$ & $0.0787 \mathrm{in.}-0.101 \mathrm{in}$. \\
\hline Initial Horizontal Seat Area, $\mathrm{A}_{\mathrm{hi}}=\pi\left(\mathrm{r}_{\mathrm{i}}{ }^{2}-5 / 16^{2}\right)$ & $0.174 \mathrm{in}^{2}$ \\
\hline Final Horizontal Seat Area, $\mathrm{A}_{\mathrm{hf}}=\pi\left(\mathrm{r}_{\mathrm{f}}{ }^{2}-5 / 16^{2}\right)$ & $0.231 \mathrm{in}$ \\
\hline Average Wear Rate, $\left(\mathrm{r}_{\mathrm{f}}-\mathrm{r}_{\mathrm{i}}\right) /\left(\mathrm{t}^{*} 2^{2 / 2}\right)$ & $0.00305 \mathrm{in} / \mathrm{hr}$ \\
\hline Friction Coefficient, $\mu_{\mathrm{f}}$ & 0.0802 \\
\hline Friction Power $=\mathrm{V}_{\mathrm{c}}{ }^{*} \mathrm{~F}_{\theta}=\mathrm{V}_{\mathrm{c}}{ }^{*} \operatorname{Load}^{*} \mu_{\mathrm{f}}$ & $29.2\left(\mathrm{~b}_{\mathrm{f}}{ }^{*} \mathrm{in}\right) / \mathrm{sec}$ \\
\hline
\end{tabular}


Shown in Figure 6.16 are the average friction coefficients for the material combinations tested.

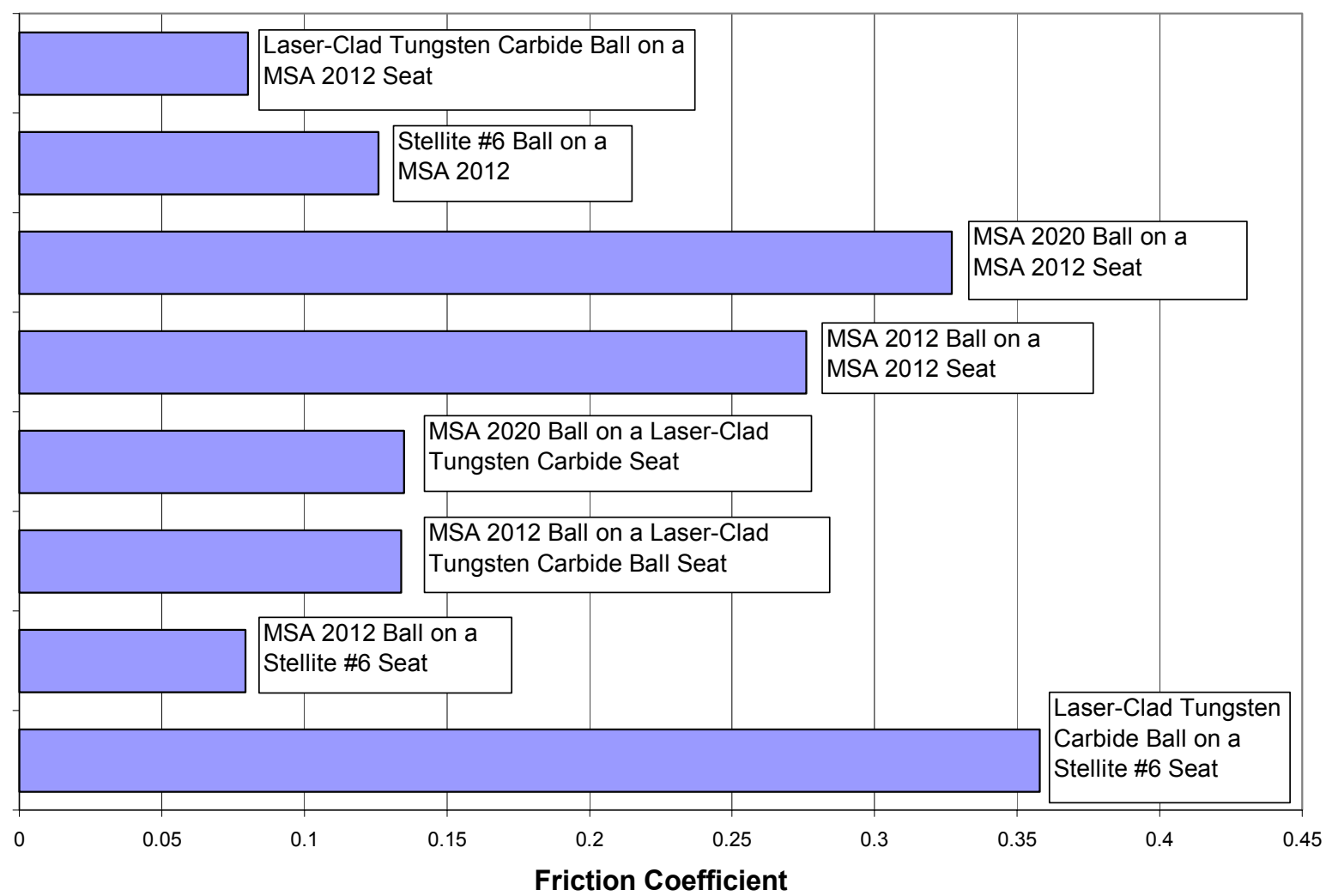

Figure 6.16: Average Friction Coefficients of Bearing Material Combinations

The friction power of each material combination was calculated using the average friction coefficient for that material in Equation 5.5. Figure 6.17 shows a comparison of the friction power for each material combination tested. 


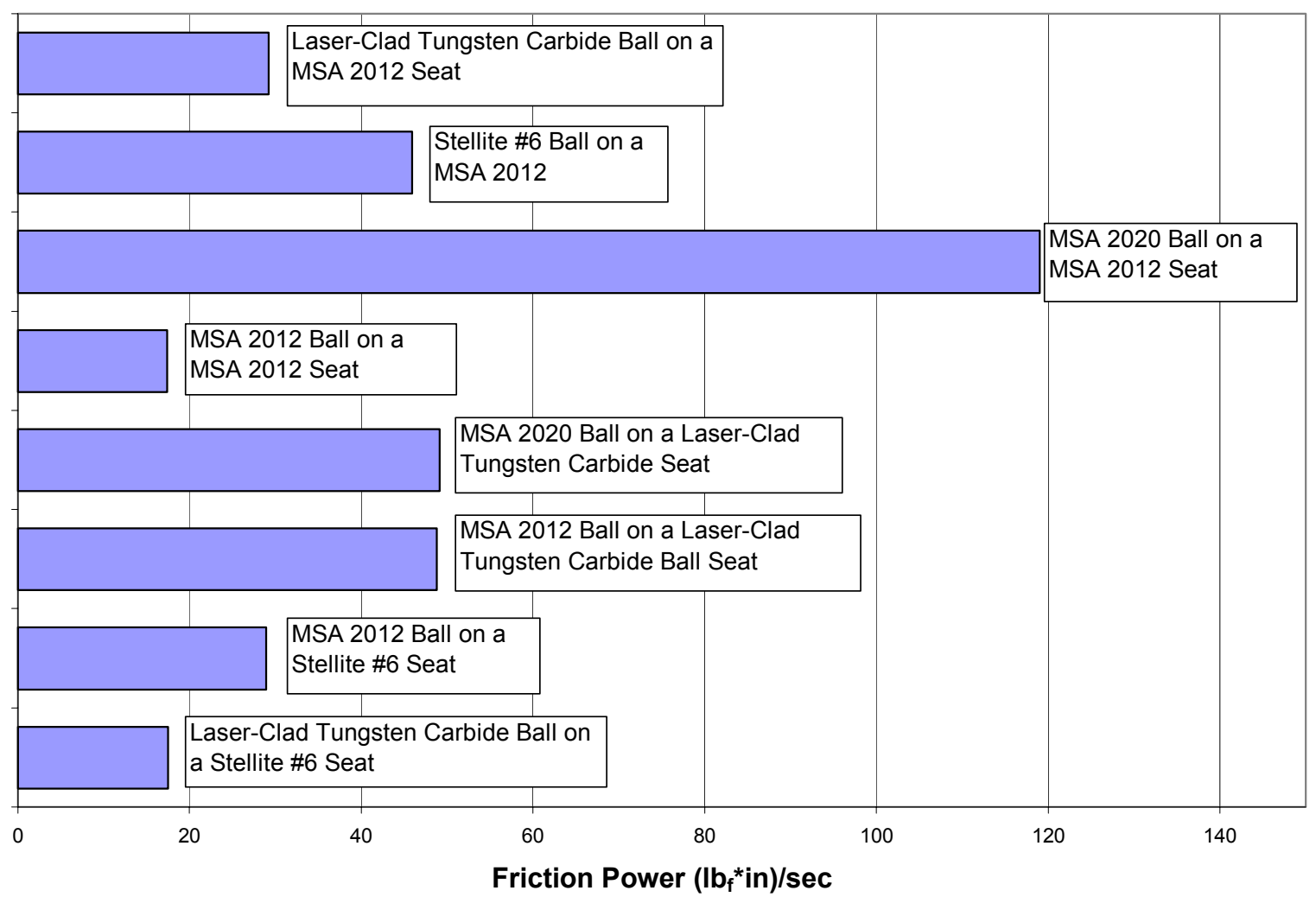

Figure 6.17: Friction Power of Bearing Material Combinations

A correlation between bearing loading power and wear rate was also constructed, shown in Figure 6.18. From this Figure it was concluded that the Laser-Clad Tungsten carbide seat lasted the longest. 


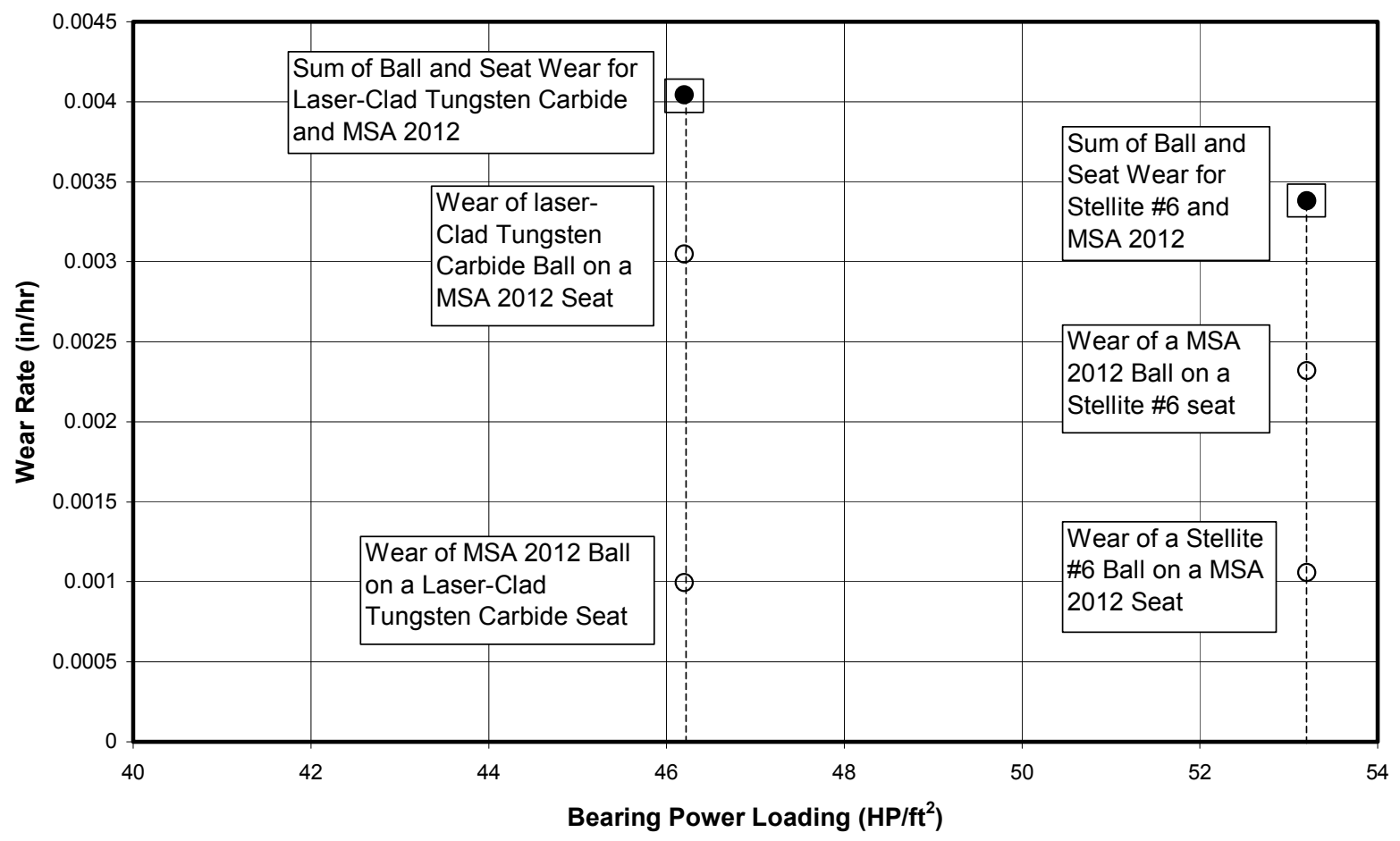

Figure 6.18: Material Combinations Wear Rate as a

Function of Bearing Power Loading $=\mathbf{P}_{\mathbf{C}} * \mathbf{V}_{\mathbf{C}}$ 


\section{Chapter 7 - Conclusion}

The apparent longest lasting zinc pot bearing material seat specimen tested was the laser-clad tungsten carbide on stainless steel. This material showed little wear when tested against other bearing materials. From collected data the wear rate of bearing materials appears linear with time and with contact velocity. This relationship appears to hold for a variety of bearing materials. However, the wear rate as a function of contact pressure appears to be non-linear. The degree of non-linearity is dependent on the bearing material combination.

The data collected by the WVU zinc pot bearing materials tester shows that the machine operates as designed and able to cover the operational range of typical steel mill galvanizing lines. The zinc pot bearing materials tester has numerous safety features built into it that make it safe to operate.

In a paper titled "Dynamics of Journal Bearings on the Stabilizer and Sink Rolls in a Zinc Pot" written by Mark Bright and Gregory Becherer of the Metaullics Systems Company the lubrication of zinc pot bearings was addressed. The type of lubrication regime in zinc pot bearings depends on lubricant viscosity $(Z)$, bearing rotational speed $(\mathrm{N})$ and bearing load pressure $(\mathrm{P})$. These three variables determine whether the bearings are operating in one of three regimes: boundary lubrication, mixed film lubrication or hydrodynamic lubrication. Hydrodynamic lubrication produces a complete separation of the two bearing surfaces, where in boundary lubrication there is virtually no fluid-film present. In order to determine which regime that the bearings are operating in, the friction coefficient is plotted as a function of $\mathrm{ZN} / \mathrm{P}$. This is commonly known as a Striebeck Curve. In this paper a sheet speed of $600 \mathrm{ft} / \mathrm{min}$, a sheet tension of $6000 \mathrm{lb}_{\mathrm{f}}$ and 
a zinc viscosity of 3.3 centipoise determined a $\mathrm{ZN} / \mathrm{P}$ value of 0.984 . This value indicates that the bearings are operating in the boundary lubrication regime. 


\section{References}

[1] K. Chang, G. Psaros, J.J. Brinsky, R.L. Nester, R. Carter, V. Sikka, "New Material Research and Life Improvement for Pot Hardware in Continuous Hot-Dipping Processes," Steel Industry of the Future.

[2] R.E. Bond, J.L. Loth, R.W. Guiler, and N.N. Clark, "Lubricity Problems and Solutions for a Methanol Fueled Gas Turbine," Rheology and Fluid Mechanics of Nonlinear Materials, FED-Vol 252.

[3] American Society for Testing and Materials, Standard Handbook Method for Measurement of Lubricity of Aviation Fuels by Ball on Cylinder Lubricity Evaluator, D5001-90a(1995)a American Society for Testing and Materials, West Conshohocken, PA., 1999.

[4] Lubrizol Corporation, Lubrizol Scuffing BOCLE, http://www.lubrizol.com/referencelibrary/news, Lubrizol Corporation, 2000.

[5] Rabinowicz, Ernest, Friction and Wear of Materials, John Wiley \& Sons, Inc., New York, 1995, pgs 239-250.

[6] Teck Cominco LTD, "Continuous Galvanizing Line (CGL) Submerged Hardware Research," October 1996.

[7] Teck Cominco LTD, "Study of Hydrodynamic Bearing Operation with Cominco's Full Journal Bearing Test Rig," November 1999.

[8] Oberg, Eric, and Jones, F.D., Machinery's Handbook, $16^{\text {th }}$ Edition, The Industrial Press, New York, NY, 1962, pg. 509.

[9] H. Zoz, H.U. Benz, K. Huttebraucker, L. Furken, H. Ren, R. Reichardt, "Stellite bearings for liquid Zn-/Al-system with advanced chemical and physical properties by MA," Metall 54, Jahigang, November 2000.

[10] El-Madg, M.A. Shaker, R. Hechor, A.E. Nasser, Mechanical Behavior of Stellite 6 Produced by Powder. Metallurgicaly Process, $6^{\text {th }}$ Int. Conf. On Mechanical Design and Production (mpd-6). Cairo, Egypt. 1996.

[11] B.G. Seong, S.Y. Hwang, M.C. Kim, K.Y. Kim, "Reaction of WC-Co coating with molten zinc in a zinc pot of a continuous galvanizing line," Surface and Coatings Technology, 138 (2001) 101-110.

[12] P. Gilorimini, P. Durighello, F. Nonne, "Bearing tester for bath hardware material," Arcelor Research/IRSID, Galvanizers' Association Meeting, October 2002. 
[13] Ware, R.T., "Design and Construction of Zinc Pot Bearing Material Wear Tester," Thesis, West Virginia University, Department of Mechanical and Aerospace Engineering, August, 2002. 


\title{
Appendix A - Quick Basic ${ }^{\circledR}$ Data Acquisition Computer Program
}

\author{
DIM L AS INTEGER ～' dimensions load output variable as an integer \\ DIM Q AS INTEGER 'dimensions torque output variable as an integer \\ DIM TP AS INTEGER 'dimensions temperature output variable as an integer \\ DIM R AS INTEGER 'dimensions RPM output variable as an integer \\ DIM lv AS INTEGER ' 'dimensions load input signal as a single precision \\ 'floating point variable \\ DIM tqv AS INTEGER 'dimensions torque input signal as a single precision \\ 'floating point variable \\ DIM tpv AS INTEGER 'dimensions temperature input signal as a single precision \\ 'floating point variable \\ DIM rv AS INTEGER 'dimensions RPM input signal as a single precision \\ 'floating point variable \\ DIM sampletime AS LONG 'dimensions test duration time as an integer variable
}

DECLARE FUNCTION adcin\% (chan AS INTEGER, datv AS SINGLE) 'declares the subroutine function found at the end of this program and dimensions the 'channel as an integer and dimensions the voltage signal as a single precision floating 'point variable

CLS 'clears data output screen before data collection begins

ON TIMER (1) GOSUB pace: $\quad$ 'sets timer at 1 second interval and branches to the 'subroutine

TIMER ON ' 'turns on timer

FILE $=7090505 \quad$ 'sets the file name to month/day/time based on user input

PRINT "File Name=" ; FILE ' 'prints the file name to the output screen

PRINT" TIME LOAD TQ TEMP

'prints titles at the top of each respective column of data on the output screen

OPEN "A:17090505.txt" FOR OUTPUT AS \#1

'opens drive A to output data to a floppy disk 
PRINT \#1, "File Name=" ; FILE 'prints file name defined above to the floppy disk

PRINT \#1, " TIME $(\mathrm{mV}) \quad \operatorname{LOAD}(\mathrm{mV}) \quad \mathrm{TQ}(\mathrm{mV}) \quad$ TEMP $(\mathrm{mV}) \quad$ RPM $(\mathrm{mV})$ " 'prints titles at the top of each respective column of data to the floppy disk

sampletime $=0 \quad$ 'sets sample time to 0 at the beginning of the test

TIMER ON 'turns timer on

DO 'starts the beginning of a loop

LOOP UNTIL sampletime $>900$

'maintains the loop until the sample time is greater than 900 seconds

STOP 'stops the loop once the sample time has reached 900 seconds

pace: 'sets the channels that the subroutine will scan

$$
\begin{aligned}
& \mathrm{L}=\operatorname{acdin}(5+64, \mathrm{lv}) \quad \text { 'load is on channel } 5 \text { with a gain of } 100 \\
& \mathrm{TQ}=\operatorname{acdin}(1+64, \mathrm{tqv}) \quad \text { 'torque on channel } 1 \text { with a gain of } 100 \\
& \mathrm{TP}=\operatorname{acdin}(3+32, \mathrm{tpv}) \quad \text { 'temperature on channel with a gain of } 10 \\
& \mathrm{R}=\operatorname{acdin}(2, \mathrm{rv}) \quad \text { 'RPM on channel } 2 \text { with } \text { a gain of } 1
\end{aligned}
$$

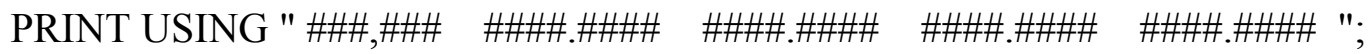

sampletime; lv; tqv; tpv; rv

'prints the output data to the output screen with the user specified number of 'significant figures

sampletime $=$ sampletime $+1 \quad$ 'iterates sample time by 1 second in the loop

PRINT \#1, sampletime, lv, tqv, tpv, rv

'prints the time and collected data to the floppy disk

RETURN 'returns subroutine to the loop

'beginning of subroutine

FUNCTION adcin\% (chan AS INTEGER, datv AS SINGLE)

'begins function rpocedure and dimensions channels as integers and data voltage signals 'as floating point variables

CONST adr $=\& \mathrm{H} 300 \quad$ 'sets the base address of the RTI 800 board at $300 \mathrm{H}$

DIM dat AS INTEGER 'dimensions data signal as integer 
'set channel

OUT adr +1 , chan 'goes out to RTI 800 board to the multiplexer/gain select ' 'byte at abse address $300 \mathrm{H}+1$ where the channel signal 'start conversion 'gain is set

OUT adr $+2,0 \quad$ 'goes out to the RTI 800 board to the convert command byte ' 'at base address $300 \mathrm{H}+2$ which is not used

'wait for end of conversion

DO 'starts the beginning of a loop

LOOP UNTIL (INP (adr) AND \&H40) $>0$

'executes a relational test to check for the data signal

dat $=\mathrm{INP}(\mathrm{adr}+3)+(\mathrm{INP}(\mathrm{adr}+4)$ AND \&HF $) * 256$

'collects 8 bits of data signal at base address $300 \mathrm{H}+3$ and collects 4 bits of data 'at base address $300 \mathrm{H}+4$ which is added to the first 8 bits to create a 12 bit 'signal

IF (dat AND \&H800) $>0$ THEN

$$
\text { dat }=\text { dat OR \&HF000 }
$$

'checks if data signal is greater that 0 , if it is true then the program writes the 'data to the output screen, if it is false then the program writes a row of zeroes 'to the output screen

END IF 'ends IF statement

datv $=$ dat $* 20000 ! / 4095$ !

'converts the collected 12 bit binary signal to a voltage signal

adcin $=$ dat $\quad$ 'sets subroutine equal to the data signal

END FUNCTION 'ends subroutine function 


\section{Appendix B - Calibration Procedure}

The torque strain gage beam was calibrated by attaching a string to the beam and hanging know weights form the string. The string was attached to a pulley, which transfers the force to the horizontal direction. The output voltage was read for each respective weight and a calibration curve was then constructed. The same curve is obtained for increasing or decreasing loads. The calibration curve for the torque strain gage beam can be seen in Figure B.1.



Figure B.1: Calibration Curve for Torque Strain Gage Beam $F_{\text {Gage }}$ with Moment Arm $\mathbf{l}_{\text {Gage }}=6.75$-inch

The load cells were calibrated in a similar fashion by placing known weights on the cup torque transfer plate and recording the output voltage. It was then possible to generate a calibration curve for the load cells as seen in Figure B.2. 


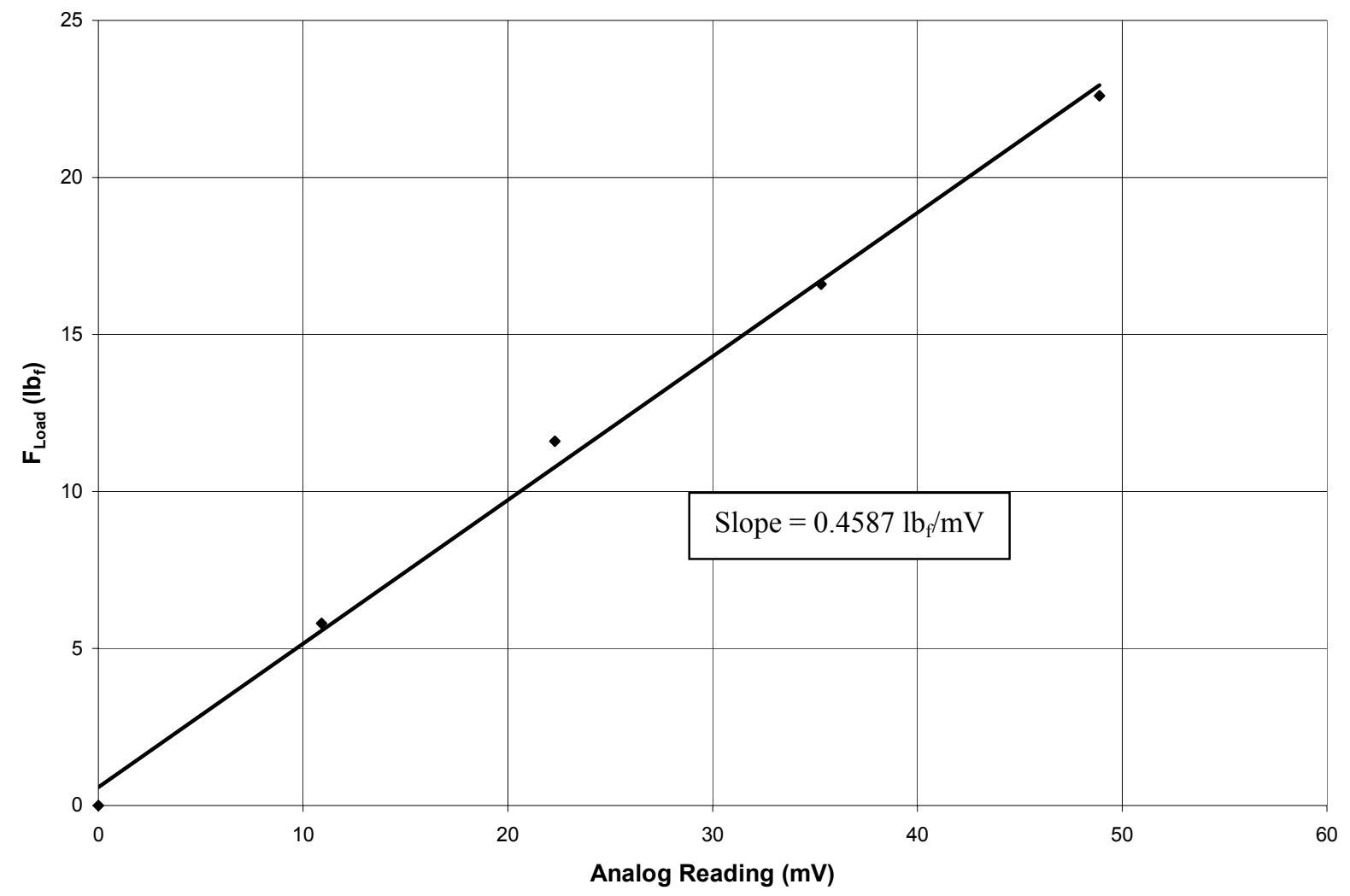

Figure B.2: Calibration Curve for Load Cells

The RPM sensor was calibrated by attaching the sensor to a vertical mill and reading the voltage output from the RPM meter at various speeds. A calibration curve for this instrument can be found in Figure B.3. 




Figure B.3: Calibration Curve for RPM Sensor

A calibration of the type $\mathrm{K}$ thermocouple was not necessary, because the manufacturer provided a calibration constant. The constant provided was $1^{\circ} \mathrm{F} / \mathrm{mV}$ for the type $\mathrm{K}$ thermocouple and thermometer readout. 


\section{Appendix C - Zinc Composition}

Table C.1: Chemical Composition Analysis for Molten Zinc Used in Testing.

\begin{tabular}{|c|c|c|c|c|c|c|c|}
\hline & $\begin{array}{l}\mathrm{Al} \\
\%\end{array}$ & $\begin{array}{l}\mathrm{Cu} \\
\%\end{array}$ & $\begin{array}{l}\mathrm{Fe} \\
\%\end{array}$ & $\begin{array}{l}\mathrm{Pb} \\
\%\end{array}$ & $\begin{array}{l}\mathrm{Cd} \\
\%\end{array}$ & $\begin{array}{l}\mathrm{Si} \\
\% \\
\end{array}$ & $\begin{array}{l}\mathrm{Zn} \\
\%\end{array}$ \\
\hline \multicolumn{8}{|c|}{ Zinc Start-up Material } \\
\hline Bulk Material & 0.1593 & 0.0005 & 0.0131 & 0.0019 & 0.0010 & $<0.0003$ & 99.82 \\
\hline \multicolumn{8}{|l|}{ Static Test } \\
\hline Alloy $4500 \mathrm{~h}$ & 0.1688 & 0.0005 & 0.0156 & 0.0022 & 0.0010 & $<0.0003$ & 99.81 \\
\hline Alloy 4-1 500h & 0.1689 & 0.0004 & 0.0163 & 0.0021 & 0.0008 & $<0.0003$ & 99.81 \\
\hline Alloy 4-2 500h & 0.1674 & 0.0004 & 0.0147 & 0.0020 & 0.0007 & $<0.0003$ & 99.81 \\
\hline Alloy 4-4 500h & 0.1723 & 0.0005 & 0.0167 & 0.0022 & 0.0010 & $<0.0003$ & 99.81 \\
\hline \multicolumn{8}{|l|}{ Dynamic Test } \\
\hline Top Dross 48h & 0.4400 & 0.0004 & 0.0169 & 0.0019 & 0.0009 & $<0.0003$ & 99.54 \\
\hline
\end{tabular}

Average $(n=3)$ 


\section{Appendix D - Error Analysis}

An error analysis was performed on the friction coefficient and wear rate data collected. In order to determine the uncertainty of the friction coefficient, $\omega_{\mu \mathrm{F}}$, the following formula was used.

$$
\omega_{\mu_{F}}=\left[\left[\left(\frac{\partial \mu_{F}}{\partial F_{\text {gage }}}\right) * \omega_{F_{\text {gage }}}\right]^{2}+\left[\left(\frac{\partial \mu_{F}}{\partial F_{\text {load }}}\right) * \omega_{F_{\text {load }}}\right]^{2}\right]^{1 / 2}
$$

By taking the required partial derivatives of Equation 5.1 and using them in the above equation, the following relation results.

$$
\omega_{\mu_{F}}=\left[\left[\left(\frac{13.5}{F_{\text {load }}}\right) * \omega_{F_{\text {gage }}}\right]^{2}+\left[\left(\frac{-13.5 * F_{\text {gage }}}{\left(F_{\text {load }}\right)^{2}}\right) * \omega_{F_{\text {load }}}\right]^{2}\right]^{1 / 2}
$$

Next, the uncertainties of the load, $\omega_{\text {Fload}}$, and torque, $\omega_{\text {Fgage }}$, were determined. This was done by assuming the uncertainty for each variable to be three times the standard deviation of the load cells and torque strain gage beam. In order to determine each respective uncertainty, a known weight was applied to the load cells and torque strain gage beam in the same manner as was done for their calibration, as seen in Appendix B. The known weight was applied twenty times and the reported output from the load cells and torque strain gage beam was recorded and a standard deviation of this data was determined. The standard deviation of the load cells and torque strain gage beam was found to be $0.0284 \mathrm{lb}_{\mathrm{f}}$ and $0.0195 \mathrm{lb}_{\mathrm{f}}$ respectively. When the standard deviations were multiplied by three and substituted into Equation D.2, the uncertainty of the friction 
coefficient can be determined from Equation D.3 and shown by error bars on the applicable data Figures.

$$
\omega_{\mu_{F}}=\left[\left[\left(\frac{13.5}{F_{\text {load }}}\right) *(0.0585)\right]^{2}+\left[\left(\frac{-13.5 * F_{\text {gage }}}{\left(F_{\text {load }}\right)^{2}}\right) *(0.0852)\right]^{2}\right]^{1 / 2}
$$

The uncertainty of the wear rate, $\omega_{\mathrm{wr}}$, was determined in a similar manner to that of the friction coefficient. The uncertainty of the wear rate was defined as the following.

$$
\omega_{w r}=\left[\left[\left(\frac{\partial(w r)}{\partial(\text { wear depth })}\right) * \omega_{\text {wear }}\right]^{2}+\left[\left(\frac{\partial(w r)}{\partial t}\right) * \omega_{t}\right]^{2}\right]^{1 / 2}
$$

By taking the partial derivatives of the relationship for wear rate, Equation 5.5, the following uncertainty for wear rate is found.

$$
\omega_{w r}=\left[\left[\left(\frac{1}{t}\right) * \omega_{\text {wear depth }}\right]^{2}+\left[\left(\frac{- \text { wear depth }}{t^{2}}\right) * \omega_{t}\right]^{2}\right]^{1 / 2}
$$


division on the optical magnifier divided by $\sqrt{ } 2$, which is equal to 0.0014 -inches. The uncertainty in the time measurement, $\omega_{\mathrm{t}}$, was determined to be 1 minute based on clock used for time keeping. With the use of these uncertainties, a relation for the uncertainty in the wear rate was determined.

$$
\omega_{w r}=\left[\left[\left(\frac{1}{t}\right) *(0.0014)\right]^{2}+\left[\left(\frac{- \text { wear depth }}{t^{2}}\right) *\left(\frac{1}{60}\right)\right]^{2}\right]^{1 / 2}
$$


The final uncertainty to be determined was the contact pressure, $\mathrm{P}_{\mathrm{c}}$. The contact pressure is found by dividing the load by the horizontal projected area, $A_{h}$. The uncertainty of the contact pressure, $\omega_{\mathrm{Pc}}$, is defined as follows.

$$
\omega_{P_{C}}=\left[\left[\left(\frac{\partial P_{C}}{\partial A_{h}}\right) * \omega_{A_{h}}\right]^{2}+\left[\left(\frac{\partial P_{C}}{\partial F_{\text {load }}}\right) * \omega_{F_{\text {load }}}\right]^{2}\right]^{1 / 2}
$$

By substituting the required partial derivatives of the contact pressure into the above equation, an uncertainty for the contact pressure was determined.

$$
\omega_{w r}=\left[\left[\left(\frac{-F_{\text {load }}}{A_{h}^{2}}\right) * \omega_{A_{h}}\right]^{2}+\left[\left(\frac{1}{A_{h}}\right) * \omega_{F_{\text {load }}}\right]^{2}\right]^{1 / 2}
$$

The uncertainty for the load cells is the same as determined previously, $0.0852 \mathrm{lb}_{\mathrm{f}}$. The uncertainty of the horizontal projected area was taken as half of the smallest scale division on the optical magnifier squared and multiplied by $\pi$, which is equal to 0.000013-inches. With the use of these two uncertainties the following equation for the uncertainty of the contact pressure was determined.

$$
\omega_{w r}=\left[\left[\left(\frac{-F_{\text {load }}}{A_{h}^{2}}\right) *(0.000013)\right]^{2}+\left[\left(\frac{1}{A_{h}}\right) *(0.0852)\right]^{2}\right]^{1 / 2}
$$

The above Equations, D.3, D.6 and D.9, were used to determine the error in the friction coefficient, wear rate and contact pressure. 